FTI29 360

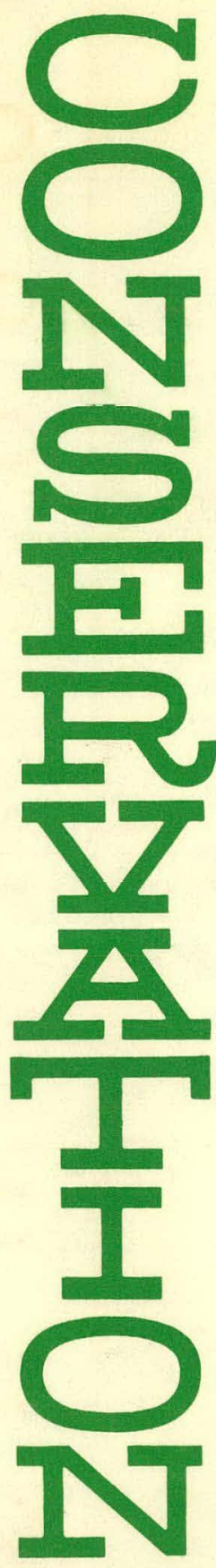

DR. 1310

SAN-1176-T1(Vol.2)

\section{ENERGY STUDY OF RAILROAD FREIGHT TRANSPORTATION}

Volume 2: Industry Description

\section{MASTER}

August 1979

Work Performed Under Contract No. EY-76-C-03-1176

Stanford Research Institute

Menlo Park, California

\title{
U. S. DEPARTMENT OF ENERGY
}

\author{
Division of Transportation Energy Conservation
}




\section{DISCLAIMER}

This report was prepared as an account of work sponsored by an agency of the United States Government. Neither the United States Government nor any agency Thereof, nor any of their employees, makes any warranty, express or implied, or assumes any legal liability or responsibility for the accuracy, completeness, or usefulness of any information, apparatus, product, or process disclosed, or represents that its use would not infringe privately owned rights. Reference herein to any specific commercial product, process, or service by trade name, trademark, manufacturer, or otherwise does not necessarily constitute or imply its endorsement, recommendation, or favoring by the United States Government or any agency thereof. The views and opinions of authors expressed herein do not necessarily state or reflect those of the United States Government or any agency thereof. 


\section{DISCLAIMER}

Portions of this document may be illegible in electronic image products. Images are produced from the best available original document. 


\section{DISCLAIMER}

"This book was prepared as an account of work sponsored by an agency of the United States Government. Neither the United States Government nor any agency thereof, nor any of their employees, makes any warranty, express or implied, or assumes any legal liability or responsibility for the accuracy, completeness, or usefulness of any information, apparatus, product, or process disclosed, or represents that its use would not infringe privately owned rights. Reference herein to any specific commercial product, process, or service by trade name, trademark, manufacturer, or otherwise, does not necessarily constitute or imply its endorsement, recommendation, or favoring by the United States Government or any agency thereof. The views and opinions of authors expressed herein do not necessarily state or reflect those of the United States Government or any agency thereof."

This report has been reproduced directly from the best available copy.

Available from the National Technical Information Service, U. S. Department of Commerce, Springfield, Virginia 22161.

Price: Papcr Copy $\$ 10.00$

Microfiche $\$ 3.50$ 


\title{
ENERGY STUDY OF RAILROAD FREIGHT TRANSPORTATION
}

\author{
Volume 2: Industry Description
}

August 1979

Work Performed Under Contract No. EY-76-C-03-1176

Prepared for:

U. S. Department of Energy Systems Efficiency Branch Transportation Programs Office

Stanford Research Institute Menlo Park, California 


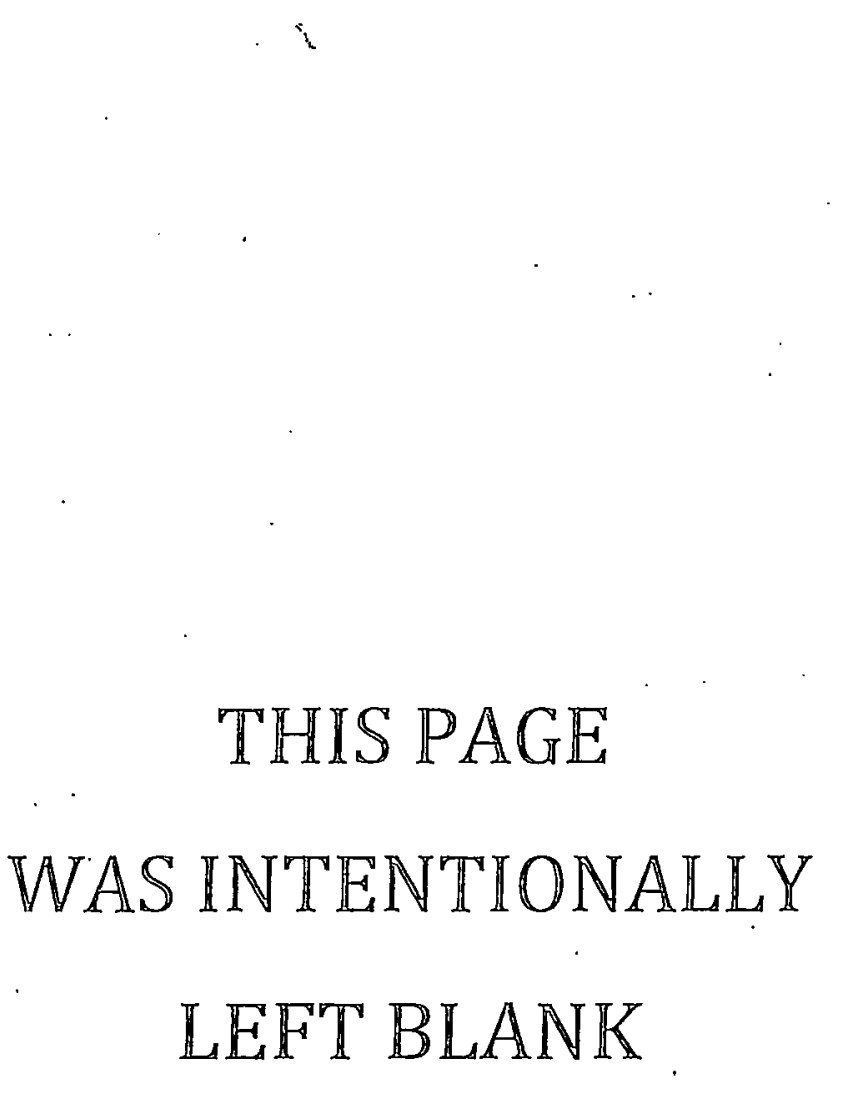


TABLE OF CONTENTS

LIST OF ILLUSTRATIONS. . . . . . . . . . . . . . . . . . . . v v

LIST OF TABLES . . . . . . . . . . . . . . . . . . . . vii v vi

PREFACE . . . . . . . . . . . . . . . . . . . . . . ix

I INTRODUCTION . . . . . . . . . . . . . . . ${ }^{-} 1$

II SUMMARY . . . . . . . . . . . . . . . . . . . . 3

Railroad Services... . . . . . . . . . . . . 3

Railroad Facilities . . . . . . . . . . . . . 4

Railroad Costs . . . . . . . . . . . . . . . . 5

Railroad Energy . . . . . . . . . . . . . . 6

III RAILROAD HISTORY . . . . . . . . . . . . . . 7

Intercity Railroads . . . . . . . . . . . . . . . . . 7

Engineering Standards, and Methods and Equipment

for Construction .. . . . . . . . . . ...... 13

Maturing and Decline of the Industry . . . . . . . . . 13

Institutional Features . . . . . . . . . . . . . . 14

IV THE FREIGHT RAILROAD SYSTEM . . . . . . . . . . . . . . 17

Freight Services . . . . . . . . . . . . . . . . . 17

The Freight Railroad Industry . . . . . . . . . . . . 20

Physical Facilities of the Freight Railroad System . . . . 21

Railroad Network . . . . . . . . . . . . . . . . 24

Locomotive Power . . . . . . . . . . . . . . . . . 32

Railroad Cars... . . . . . . . . . . . . . . 33

Train Control (Signaling). . . . . . . . . . . . . . 38

Miscellaneous Other Equipment . . . . . . . . . . . 42

V RAILROAD COSTS .................... . . . 45

Problems of Analyzing Railroad Costs . . . . . . . . . . 45

Cost of Railroad Facilities and Services . . . . . . . . . 46

Abstract Railroad Network................ . 47

Generalized Economic Framework . . . . . . . . . . . . 48

A Company-by-Company Approach to Railroad Costs . . . . . 66 
VI RALLROAD ENERGY CONSUMPTION . . . . . . . . . . . . 85

Types and Amounts of Energy Consumed . . . . . . . . 85

Energy Computations in the Models... . . . . . . . . 91

Investment of Energy in Railroad Facilities . . . . . . . 97

APPENDTCES

A CORRIDOR NETWORK DESCRIPTION . . . . . . . . . . . . : 99

B RAILROAD ENERGY USE AND FUEL CONVERSION . . . . . . . . . 119

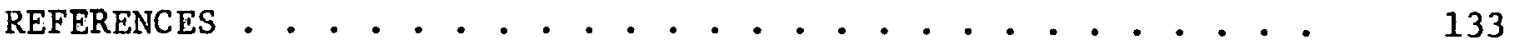


ILLUSTRATIONS

1 Annual Mileage of Railroad Constructed in the United States (1830-1962) . . . . . . . . . . . . . 9 9

2 Annual Mileage of Railroad Abandoned in the United States (1921-1962) . . . . . . . . . . . . . . . 10

3 Mileage of Railroad Owned in the United States (1871-1962)..................... 11

4 Distribution of Commodities Hauled by Railroads 22

5 Map of United States Right of Way. . . . . . . . . . . 25

6 Typical Flat-Yard Track Configuration. . . . . . . . . . 27

7 Typical Arrangement of Subyards in a Humpyard. . . . . . . 29

8 Geometric Pattern of Classification Tracks in a Humpyard . . . . . . . . . . . . . . . . 29

9 Abstract Railroad Network. . . . . . . . . . . . 47

10 Mainline Component--Long Run Average Cost Model--Default Input. . . . . . . . . . . . . . . . . . . 55

11 Average Net Tons . . . . . . . . . . . . . . 60

12 Density--Net Ton-Miles per Mile . . . . . . . . . . . 61

13 Long-Run Average Cost of Switchyard Operations . . . . . . 67

14 Short and Long Runs Average Costs. . . . . . . . . . . . . 73

15 Distribution of Railroad Ton-Miles, 1973 Freight Service . 88

16 Mainline Component--Fuel and Average Cost Versus Speed . . 93

17 Mainline Component--Fuel and Average Cost Versus Empty and Loaded Cars Ratio. . . . . . . . . . . . . . . . . . 94

18 Way Switching TRMN Variation of Average Cost and Fuel Consumption with Train Length. . . . . . . . . . . 95

A-1 Nationwide Trunk and Connecting Railroad Lines . . . . . 102

B-1 Freight Car Resistance . . . . . . . . . . . . 123

B-2 Illustration of Class C Grade Energy Requirement . . . . . 127

B-3 Specific Fuel Consumption for SD-45 Locomotive . . . . . 130 
THIS PAGE

\section{WAS INTENTIONALLY LEFT BLANK}


TABLES

1 U.S. Railroad Mileage . . . . . . . . . . . . 8

2 Miles of Single- and Mu1tiple-Track Railroad by

Traffic Density . . . . . . . . . . . . . . 23

3 Summary of Yard Inventory . . . . . . . . . . . . . . 31

4 Estimated Population of Locomotives by Horsepower and Manufacturers . . . . . . . . . . . . . . . 34

5 Production of Locomotives by Type by Electromotive Division of General Motors (EMD) and General Electric (GE) to 1 January 1976 . . . . . . . . . . . . . . . . .

6 EMD Locomotives in Service for 26 Class I Railroad Companies on 1 January 1976 . . . . . . . . . . . . . . . 36

7 Ratio of Empty to Loaded Car-Miles . . . . . . . . . . 38

8 Railroad Capacity Single and Double Track, with the Various Signal Systems . . . . . . . . . . . . . .

9 Distribution of Signal Systems for Class I Railroads in the United States . . . . . . . . . . . . . 41

10 Mainline Model Variables . . . . . . . . . . . . 52

11 Factors Used in, Cost Model for Branch Line . . . . . . . 57

12 Selected Cost Components for Freight Shipments Class I Linehaul Railroads . . . . . . . . . . . . 68

13 Optima1 Trackage and Output for Selected Class I Railroads, 1974 . . . . . . . . . . . . . . 71

14 Effect of Operational Characteristics nn Railroad Costs . 75

15 The Effect of Operational Characteristics on Fuel and Labor Needs of Class I Railroads per Freight Ton-Mile . •

16 Parameters of the Estimated Short-Run Total Cost Relationship ..................... 82

17 Implied Effects of Low-Density Trackage . . . . . . . 83

18 Reported Fuel Consumption by Class I Linehaul Ra1lroads, 1973 . . . . . . . . . . . . . . . .

19 Miscellaneous Fuels, Energy, and Petroleum Products Used by Railroads, 1973 . . . . . . . . . . . . . . 
20 Estimate of Fuel Allocation for A11 U.S. Freight Railroad Operations, 1973 . . . . . . . . . . . .

21 Sensitivity of Fuel Consumed to Incremental Values of Curvature, Acceleration, and Grade for U.S. Freight Railroads in 1973 . . . . . . . . . . . . . . . . . . 91

22 Energy Content of Various Railroad Components . . . . . . 97

A-1 List of City Pairs Constituting Major Trunk and Connecting Lines in the United States . . . . . . . . . 103

A-2 Carriers with Routes Included in Corridor Description . . 104

A-3 Summary of Corridor Network Description . . . . . . . . 108

B-1 Constants for Various Types of Train Units . . . . . . . 121

B-2 Operation Data for EMP SD-40 Locomotive. . . . . . . 131 
The Energy Research and Development Administration (ERDA)*, recognizing the need for an assessment of energy usage by railroad freight and passenger services and by rail transit systems, has sponsored the Energy Study of Rail Transportation as part of a comprehensive energy conservation program. The objectives of the study were:

- To describe rail transportation systems in terms of physical, operating, and economic characteristics; and to relate energy usage, services rendered, and costs.

- To describe the roles of private and public institutions in ownership, operation, regulation, tariff, and fare determination, and subsidization of rail transportation.

- To describe possible ways to improve efficiency.

- To provide data that the Government may use to determine its future role.

Work was organized in four tasks:

- Descriptions of rail transportation industries

- Regulation, tariff, and institutional relations

- Efficiency improvements

- Industry future and federal role

Results of the study are published in two report series of four volumes each, as follows:

\section{ENERGY STUDY OF RAILROAD FREIGHT TRANSPORTATION:}

Executive Summary, Volume I

Industry Description, Volume II

Regulation and Tariff, Volume III

Efficiency Improvements and Industry Future, Volume IV

ENERGY STUDY OF RAIL PASSENGER TRANSPORTATION:

Executive Summary, Volume I Description of Operating Systems, Volume II Institutions, Volume III

Efflciency Improvements and Indistry Future, Volume IV

* The functions of ERDA have been transferred to the U.S. Department of Energy. 
The Energy Study of Rail Transportation was performcd by SRI International, Menlo Park, California, under Contract E4-76-C-03-1176. Ms. Estrella Romo and Mr. Richard Alpaugh of ERDA were the contract monitors. Dr. Robert S. Ratner was the project supervisor. Mr. Albert E. Moon was project leader and task leader for freight railroad studies. Mr. Clark Henderson was task leader for passenger rail studies.

This report is Volume II of the Energy Study of Railroad Freight Transportation. Mr. Moon was principal author. Participants in the research included: $H$. Steven Proctor, Randa11 Pozdena, Stephen J. Petracek, Judith Monaco, David Marimont, Peter Wong, Marika Garskis, and Suzelle Ruano.

The Energy Study of Railroad Freight Transportation was completed at an earlier date. Tt has not becn printed pi iur to this time because of delays in its review and so that it could be releaed simultaneously with its companion piece, the Encrgy Study of Raflroad Passenger Transportation. While more recent statistics are available for some aspects of the study, the generalized conclusions drawn and recommendations made for energy conservation actions still hold. Technologies and practices are little changed and it is believed the report can be as useful in thls form as if it were updated, which could only be accomplished at significant cost. 


\section{INTRODUCTION}

The United States railroad industry plays a key role in transporting materials to support our industrial economy. One of the oldest industries in the United States, the railroads have developed over 150 years into their present physical and operational configuration. Energy conservation proposals to change industry facilities, equipment, or operating practices must be evaluated in terms of their cost impact. The purpose of this report is to provide a current, comprehensive, and accurate data baseline of railroad economic activity and energy consumption. Descriptions of the history of railroad construction in the United States and current equipment, facilities, and operation practices follow. Economic models that relate cost and energy of railroad service to the volume of railroad output and to physical and operational parameters are provided. The analyses and descriptions should therefore provide not only an analytical baseline for evaluating the impact of proposed conservation measures, but they should also provide a measure of understanding of the system and its operations to analysts and policy makers who are involved in proposing, analyzing, and implementing such changes. 
THIS PAGE

\section{WAS INTENTIONALLY LEFT BLANK}




\section{SUMMARY}

Railroads in the United States once carried virtually all of the nation's intercity freight and passenger traffic. However, as new technologies emerged and the nation developed, the demand for railroad transportation changed drastically. Airlines and bus operators now account for over 90 percent of intercity passenger miles and the trucking industry offers stiff competition to the railroads for almost all kinds of freight. The transition of the intercity railroads to this new competitive environment has been slowed by the durability and longevity of railroad assets and by regulatory and institutional constraints that have accumulated over the years.

The railroads remain a vital link in the nation's commerce because they provide a relatively low-cost way of moving freight to a variety of places. However, railroad costs, while low on the average, vary considerably in relation to the density of traffic and utilization of equipment. The cost models developed for the project show that transportation costs are very low on densely traveled main line railroads (annual densities above about 15 million ton-miles per mile) where costs fall below 2 cents per ton-mile. On the other hand, railroad costs are very high in operations that deliver carloads to customer sidings, such as terminals or branch lines, where costs may be several dollars per ton-mile for short runs.

The utilization of energy shows a similar pattern, where over 400 ton-miles per gallon of diesel fuel might be attained on a main line, while on the branch line, where the engine must operate at idle or low speed for long periods of time while switching cars, railroad transportation may produce only 80 ton-miles per gallon of fuel.

The relative efficiency of the Iine-haul and the inefficiency of the delivery function suggesta that otrong efforte should be made to create an integrated intermodel system, whereby the railroad would perform the line-haul function that it does so well, while highway transport would be used to perform the pickup and delivery function for which it has demonstrated capability.

\section{Railroad Services}

The privipal service offered by the railroads is the movement of carloads of freight, loaded by the shipper, from shipper location to 
consignee. The carload freight moves in trains that travel between major system switchyards, where the cars are sorted into other trains until the destination is reached. Specialized services of the railroads include carriage by unit trains, trailer carriage, and container service. Unit trains are loaded at one shipper location and travel directly to one consignee destination, where they are unloaded and returned empty to the shipper, usually without being uncoupled for the entire round trip. Trailer and container services provide for the carriage of highway trailers or containers (less bogies) on flatcars to locations where they can be transferred to highway vehicles for local delivery.

About 851 billion revenue ton-miles were carried in 1973 and in 1974, with a reduction in 1975 to about 753 billion because of depressed economic conditions. In 1974, coal hauling accounted for the most carloadings and ton-miles of service and produced the greatest revenue for the railroads; it was followed, in revenue rank, by food, chemicals, farm products, transportation equipment, lumber and wood products, and pulp, paper, and allied products.

\section{Railroad Facilities and Equipment}

A railroad company can be described in terms of the facilities and equipment that are used to produce service. They are most conveniently divided into railroad line, rolling stock (1ocomotives and cars), switchyards, and miscellaneous supporting equipment.

Railroads in the United States operate about 193,000 miles of railroad, approximately $90 \%$ of it as single track. Block signals and centralized traffic control systems are used un about 80,000 miles of railroad to reduce the permissible spacing between trains and increase the capacity of the lines. The network connects with Canadian and Mexican Railroads to provide service over virtually the entire North American continent.

Most railroad trains are drawn by diesel-electric locomotives. There are just under 30,000 of these units in use, with predominant sizes in the 1,000 - to 1,500 -horsepower range for switching and in the 3,000- to 3,600-horsepower range tor line haul operations.

A fleet of 1.7 million railroad cars is used to haul the freight. of these, $25 \%$ are owned by shippers or by companies who leace cars to shippers or to the railroads; the remainder are owned by the railrnads. Princlpal types of cars are boxcars, enclosed on all sides; flat cars, providing support only for the bottom of the load; gondolas, having an open top; open or covered hoppers that provide doors in the bottom 
for rapid unloading; tank cars for carrying liquid materials; and specialized cars for carrying products that require refrigeration, heating, or specialized support for the load.

Switchyards are used to sort cars with a common destination into groups or blocks; several blocks may make up a train. There are two types of switchyards in general use, the flat switching yard and the gravity, or hump yard. The hump yard uses an elevated portion of track to provide acceleration to individual cars, which roll through a series of switches, usually remotely controlled, to arrive on a track with other cars of the same block. The flat switching yard uses a switch engine to accelerate cars on tracks in an area that is usually level. The hump yard lends itself more readily to automation because of the geometric layout of the facility. A survey in 1975 showed that there were 4,169 switchyards in the United States, of which 124 were hump yards.

The railroads also maintain track maintenance vehicles, automobiles, trucks, buses, and highway trailers; other equipment includes extensive communications equipment and computers.

$\underline{\text { Railroad Costs }}$

During this project a series of cost relationships were developed to show the variation of cost as a function of volume for linehaul operations, switchyards, and way-switching or branchline delivery operations. The models are derived from surveys taken by railroad companies and by researchers to relate such items as rail and tie wear with traffic, switch engine time with yard size and throughput, and similar factors. The relationships include the cost of facilities involved in the operations, and hence are representative of long-run average cost for the operations described. The computer programs used to compute values for the relationships are very flexible, and the capability to vary key factors is included. Additional refinements of the cost relationships may be made as they are applied to evaluate proposed improvements in later phases of the project.

The expenses reported by Class $I$ railrnads to the Interstate Commerce Commission have been analyzed to show the relationship between the company size, represented by track mileage, and the average cost per ton-mile carried. The short-run average cost for each railroad, regardless of size, shows a theoretical minimum at about 23 million gross tons annually. The long-run average cost constructed from this analysis shows that the minimum cost per ton-mile is virtually constant, regardless of the company size. In other words, no economies of scale are found between a company with a 500-track-mile system and the largest in the country. 
$\underline{\text { Railroad Energy }}$

Railroads in 1973 used a little over 4 billion gallons of diesel, fuel and about 435 million $\mathrm{kWh}$ of electricity for locomotive power. This results in an energy consumption of about 575 trillion Btu, or about 660 Btu per ton-mile of freight service. Lubricants, gasoline and heating services added an estimated 40 trillion Btu, not significant in proportion to the locomotive energy.

The railroad locomotive converts fuel energy into work that overcomes the resistance of the train on level track and increased resistance caused by grades, curves, and accelerations. Formulas for train resistance were developed almost 50 years ago and are still in widespread use. Recent research is supplying new data on resistance of trailer on flatcar units and the effects of wind on resistance. The train resistance equations have been included in the computerfzed relationships that determine average cost, and these resistance equations determine fuel cunsumption and locomotive power required for the operations in question.

It was found that idle fuel is a significant component in the operation of railroads, particularly in yards and in switching by way trains.

In regard to the fuel consumption we have exercised the model to make some estimates of energy requirements for freight movements. For main line operations the amount of back plays a considerable factor in fuel consumption. For a typical number of empty cars being hauled the model shows approximately $340 \mathrm{Btu} / \mathrm{Net}$ ton-mi. Using the branch line component of the model to analyze delivery of cars by a way train showed energy consumption of $1,377 \mathrm{Btu}$ per net ton-mile, more than twice the average of all usages.

One of the reasons for varlabllily in energy inteneiveness from different types of rallruad services is the welghl of railrosd equipment employed. Gross ton-mileage for 1973 was about 2.25 times the net ton-mileage because of locomotive, car, and caboose weight, and because railroads hauled freight an average of $17 \%$ farther than the shortest distance between origin and destination. The circuity resulted primarily from the ownership structure and revenue division rul.es applying to shipments involving more than one railroad.

Energy content of the railroad fac1lities was estimated from process and analysis and from input-output analys1s technlques. It is estimated that abuul IU quadrillion Btu alu contained in the freight cars, rails, grading, and structures in the system. This is about 20 times the annual fuel consumption for traction. 


\section{RAILROAD HISTORY}

\section{Intercity Railroads}

America has been dependent on commerce for its existence since its birth as a British colony. This commerce has been possible only because America has exploited a succession of transportation systems and networks that have supported the movement of people and goods. In early colonial days, Iife depended on ocean shipping, both transoceanic and coastal. No settlement could survive without direct access to the sea. As the new nation looked inland, canals were built to link new communities with the coast. The opening of the Midwest was facilitated by the great natural waterways that existed in that territory. By 1830 , America had a large network of natural and artificial waterways that connected all of the nation's major centers of industry and population. These waterways were traveled by ships, barges, and a variety of other craft. At this time, waterborne transport was faster and vastly more economical than any of the available forms of overland transportation.

The introduction of the railroads in 1828 led eventually to an enormous improvement in both the speed ard cost of overland transport. For nearly a full century, America was deeply involved in building its extensive network of railroads. When construction of the first railroad was begun, there were heated arguments among the competing proponents of canals, toll roads, turnpikes, and railroads. Gradually, as the economic superiority of railroads became more apparent, the pace of railroad construction accelerated. Initially, railroads were built to link navigable waterways. By. 1850 the potential of railroads was recognized and construction of an overland network was begun.

As indicated in Table 1 , more and more miles of new line were added during each succeeding decade. Following the Civil War, railroad building surged, with over 40,000 miles being added between 1870 and 1880 and over 70,000 miles between 1880 and 1890. Construction activity dropped to about 29,000 miles in the next decade but then climbed to over 47,000 in the first decade of the century. By 1916, total mileage peaked out at 254,037 and has since declined at an uneven rate to an estimated 200,000 miles at the end of 1974. Graphs of annual railroad mileage constructed, abandoned, and in existence are given in Figures 1, 2, and 3. Figure 1 shows that limited mileage of new construction has occurred nearly every year to the present but no appreciable mileage has been built since the 1930s. Since 1916, abandonments have been greater than new construction. 
Table 1

U.S. RAILROAD MILEAGE

\begin{tabular}{|c|c|c|c|c|}
\hline Year & $\begin{array}{c}\text { Total Route } \\
\text { Miles } \\
\text { (year end) }\end{array}$ & $\begin{array}{l}\text { Percent of } 1916 \\
\text { Peak Year Total }\end{array}$ & $\begin{array}{l}\text { Net } \\
(-)\end{array}$ & $\begin{array}{l}\text { Miles Added or Abandoned } \\
\text { During Preceeding Decade }\end{array}$ \\
\hline 1830 & 23 & - & & 23 \\
\hline 1840 & 2,808 & 1.1 & & 2,785 \\
\hline 1850 & 9,021 & 3.6 & & 6,213 \\
\hline 1860 & 30,626 & 12.1 & & 21,605 \\
\hline 1870 & 52,922 & 20.8 & & 22,296 \\
\hline 1880 & 93,267 & 36.7 & & 40,345 \\
\hline 1890 & 163,597 & 64.4 & & 70,330 \\
\hline 1900 & 193,346 & 76.1 & & 29,749 \\
\hline 1910 & 240,439 & 94.6 & & 47,093 \\
\hline 1916 & 254,037 & 100.0 & & Peak Year \\
\hline 1920 & 252,845 & 99.5 & & 12,406 \\
\hline 1930 & 249,052 & 98.4 & & $-3,793$ \\
\hline 1940 & 233,670 & $\dot{9} 2.11$ & & $-15,382$ \\
\hline 1950 & 223,779 & 88,1 & & $-9,891$ \\
\hline 1960 & 217,552 & 85.6 & & $-6,227$ \\
\hline 1970 & 206,265 & 81.2 & & $-11,287$ \\
\hline $\begin{array}{l}1974 \\
\text { (est.) }\end{array}$ & 200,000 & 78.7 & & \\
\hline
\end{tabular}

Sulrceo: Ref. $1,2,3$. 
1

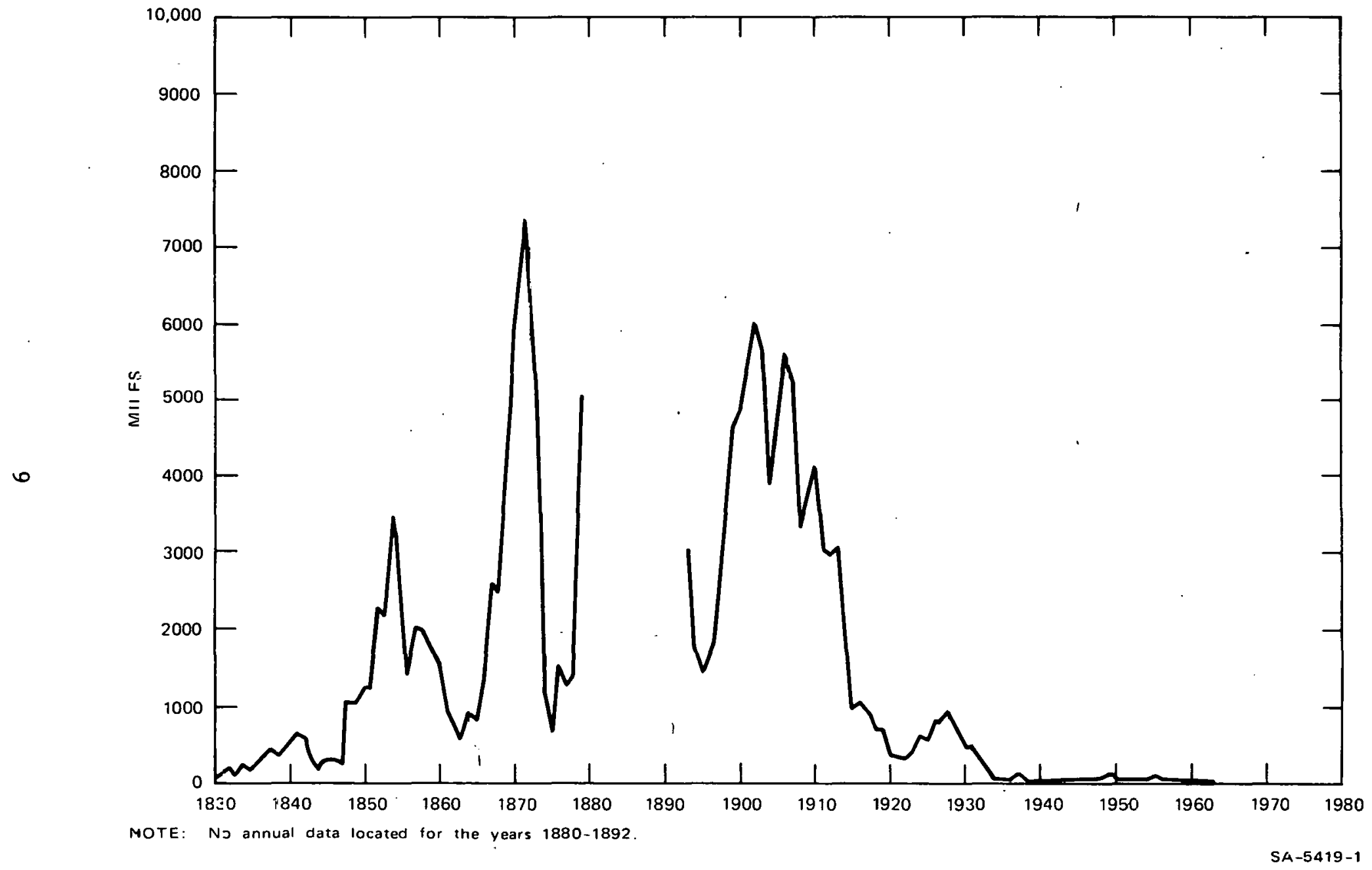

FIGURE 1 ANNUAL MILEAGE OF RAILROAD CONSTRUCTED IN THE U.S. (1830-1962) - 


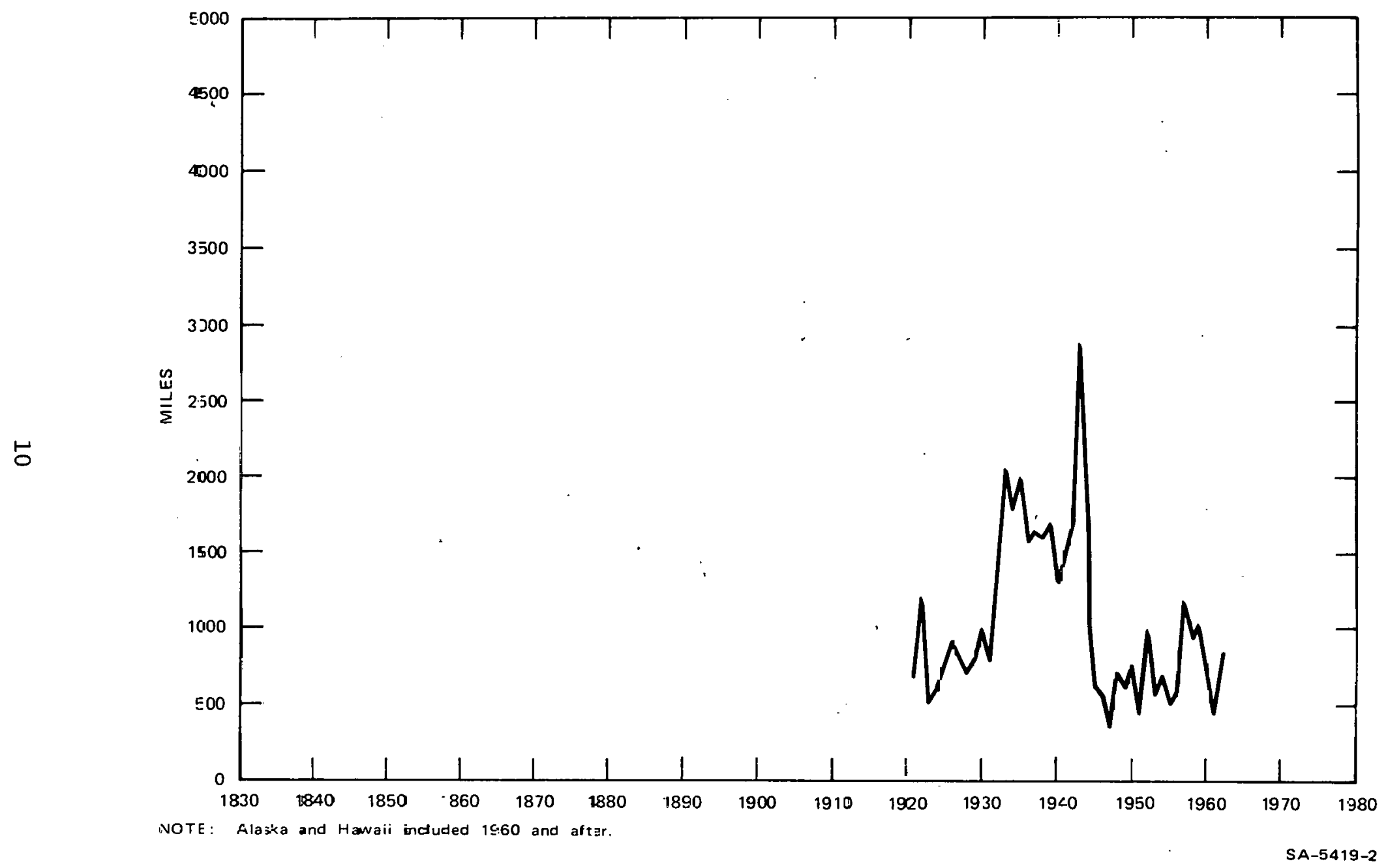

FIGURE ₹ ANNUAL MILEAGE (IF RAILROAD AEANDONEC IN THE U.S. (1921-1962) 


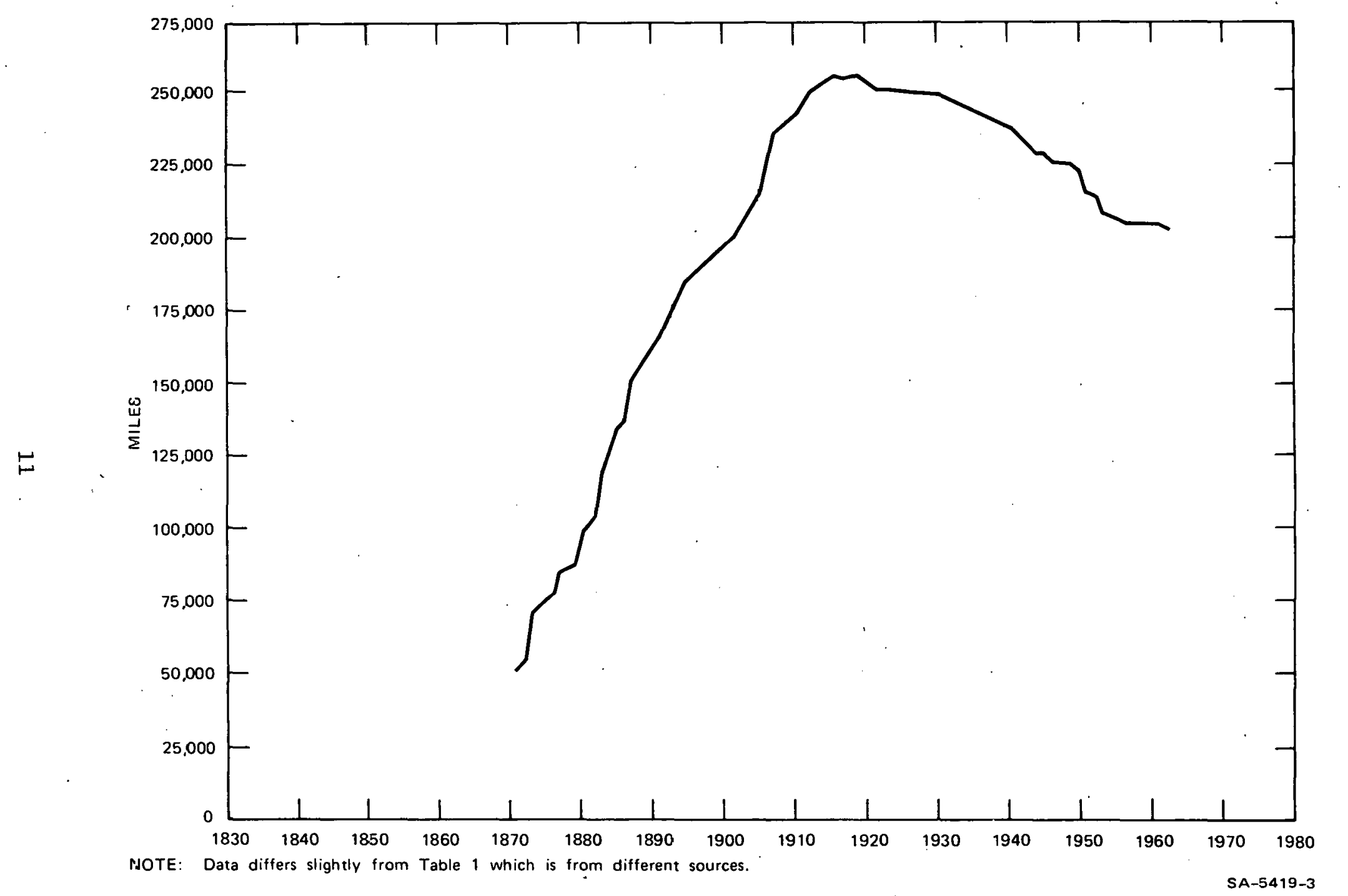

FIGURE 3 MILEAGE OF RAILROAD OWNED IN THE U.S. (1871-1962) 
Early Railroad Planning

There was no master plan by which the railroads in the United States were built. Individual lines were built to serve local needs. The resulting network was a patchwork of small companies.* What we now call "the railroad system" was not visualized at the time of its construction as a whole "system" In our modern understanding of the term. In addition, individual lines were built in an environment that was extraordinarily competitive. Success required outstanding entrapreneurial, promotional, and management skills and no little political talent and influence. A laissez-faire business environment also played an important role.

Men with great vision, zeal, and promotional skill often headed the private ventures which set out to build the railroads. More often than not, their major motivation was the prospect of making high profits from the construction of the rallroads rather than trom their operation, and in many cases this proved to be true. Railroads were new and exciting and the incentives to the builders were great. But many of the most prominent and successful individuals in the picture had little or no experience in either constructing or operating railroads. Not everyone could succeed. Such outstanding men as John C. Fremont, "The Pathfinder," failed miserably in their efforts to build railroads.

The competition among the different rallroad builders was often intense, and there was an enormous urgency to lay track as quickly as possible. Often railroad ventures were under-financed and were racing against deadlines in their charters or eager to claim land grants, government loans, or cash subsidies as quickly as possible and sometimes before a competitor did. There was also the desire to "stake out" as much territory as possible to claim its future traffic potentlal. For competitive reasons there were cases of both the threat and the actual construction of "nuisance" or parallel lines in a competitor's area (Ref. 5, p. 116). Yet another device was to build different gauges in the hope of gaining competitive advantages. As a result of these various activities, not only was excessive and duplicate mileage constructed, but circuitous routings also resulted from the desire to

* In the presentation of his "Grand Plan" for overhauling the nation's highway system to the Governors' Conference on July 12, 1954, President Eisenhower made similar observations about the historical development of our highway system:

It is obsolete and inadequate because in large part it just happened. It was governed in the beginning by terrain, existing Indian trails, cattle trails, arbitrary section lines. It was designed largely for local movement at low speeds of 1 or 2 horsepower. It has been adjusted, it is true, at intervals to meet metropolitan traffic gluts, transcontinental movement and increased horsepower. But it has never been completely overhauled or planned to satisfy the needs 10 years ahead. . . (Ref. 4, p. 1) 
minimize cost, speed construction, and maximize the benefits received from the government. At times, the railroad builders would go out of their way to pass through communities who cooperated by buying stock, lending money, and providing rights-of-way for the line, yards, and stations. Likewise they would go out of their way to avoid communities that withheld their support.

\section{Engineering Standards and Methods and Equipment for Construction}

The early approach to railroad engineering and construction was to find the easiest and least costly way to lay as much track as possible. This meant doing the barest minimum of cutting and filling and building the fewest tunnels and structures (bridges, trestles, culverts, etc.). For the large fraction of the terrain that is rolling or mountainous, a great deal of curvature was allowed as the railroad alignment followed the rivers and valleys and the contour lines of the land. At other times this design approach meant accepting heavy grades. To a considerable extent, all of these "compromises" were not as serious then as they are now. The weight of locomotives and cars was not nearly as great as it is today, and railroads were so superior in speed and cost to almost every competitive means of transport then existing that circuity of routes and slow speeds (by today's standards) made little difference.

Few standards existed. It was not until the 1880 s that the present standard gauge for track was widely adopted. At the time, more than 100,000 miles of railroad had been constructed and there were at least a dozen different track gauges in existence in the country.*

The primary and heavily used railroad routes have largely been rebuilt since this earlier day, but many secondary and branch lines still are in the same locations and on the same subgrades as were put down by the original builders.

Maturing and Decline of the Industry

The next great transportation revolution followed the invention of the internal combustion engine and the automobile. Initially, the automobile and truck were used to augment rail service by providing small shippers with pick up and delivery service. (Railway Express was such a service.) By 1920 , mass production and mass marketing brought a clamor for a system of paved highways. The Federal Aid Highway Act was passed and construction was begun on what has become a massive highway network. By 1954 highways carried $90 \%$ of intercity passenger travel. Motor

* Nearly all of the railroad mileage of Canada, Mexico, Alaska, and the 48 coterminous United States is now of standard gauge ( $4^{\prime}, 8.50$ inches) and interconnected either directly or with barges, ferries, and ships that carry railroad cars. 
carriers were responsible for almost $30 \%$ of the freight traffic, as measured in tons originated, and highways supported almost $20 \%$ of intercity freight ton-miles. In 1954, the Interstate and Defense Highway System began a further improvement in highway transport.

A review of the historical transition from one dominant transportation system to another suggests two important points:

(1) The seeds of obsolescence were evident as each great network reached the apex of its development. In 1830 when water commerce was most fully developed, the railroad had just appeared. Similarly, in 1916, when rail was king, automobile and truck transportation were becoming firmly established.

(2) As each system's popularity and dominance diminished, it was not extinguished but survived to serve a special role that was compatible with the emerging transportation system formed by the use of new technologies.

Today the inland water system plays an important role in the movement. of bulk commodities. It is particularly noteworthy that the network of waterways in use today is substantially different from the network that supported the growth of water transport in the early nineteenth century. During the post-World War II period, there was much evidence to suggest that the railroads' tenure as the dominant transportation mode had ended and that the railroads were accommodating to growing competition from highway carriers.

During the past 50 years, the transition from a railroad dominated system has been significantly influenced by public policies and regulaLluns. These regilations, which were installed to avoid monopolistic abuses by the railroads when they were dominant in the nineteenth century, have prevented the railroad network from contracting to an economically viable size. As a result, continuation of inefficient and unnatural services has been required, to the disservice of all shippers and passengers.

\section{Institutional Features}

'Ihe seeds of many of the railroad industry's problems can be traced to its early history. One such problem is the very large number of independent railroad companies that then existed. Earliest available statistics show that there were about 1000 railroad operating companies (including switching and terminal railrnads) in 1890 , and that this number increased to nearly 1,600 by 1907 . Mnre detailed data availablc in 1908 show that there were then 1,323 linehaul operating railroads (Ref. 6, Series Q44, P. 429). By 1971 , after mergers and consolidation, this number had been reduced to 346 seperate roads. Of these, there were 31 which operated as much as 1,000 miles of road (Ref. 7, Appendix C, Table 1). 
Because of the large number. of seperate entities operating railroad service, the term "Balkanized" was often used to describe the fragmented character of the industry. As this large group of companies tried to operate what became a continental railroad system, their sheer number became an impediment to efficiency and to change (Ref. 8).

A second problem stemmed to some degree from the proliferation of railroad companies. In a number of markets, intense competition existed between different railroads and between the railroads and other modes of transport. Because of concern that competition would become destructive, first State and later the Federal government formed regulatory bodies to control railroad competition. These regulatory bodies sought also to protect shippers where railroads enjoyed monopolies. (Ref. 9)

While the development of close and detailed regulation may have been beneficial to the railroads and to the public in the short run, it has been argued by many that the long-run effects have been undesirable. First, it formalized and rigidified the industry and its practices, stifled innovation, and isolated and sheltered the industry from competitive forces and necessary change. Second, it often resulted in public policies adverse to the industry's interests and denied the industry the kinds of opportunities and financial returns generally available to other parts, of the private sector.

Finally, as one of the first industries in the nation to achieve the status of "big business," the railroads had the misfortune to develop, in their early history, labor practices and relationships which came to impede change in the industry. There were some 15 major unions in the industry, each representing different crafts or categories of workers. Highly formalized work rules developed and bitter battles resulted from efforts to modernize these rules. As management sought to improve productivity and to introduce new technology and methods, and as mergers and consolidations occurred, intense efforts often centered on jobprotecting agreements and other inefficient and costly measures that had the effect of preventing or moderating the impacts and benefits of change.

Institutional factors, both in the railroad industry and among those who regulate or otherwise influence its activities and future, tended to produce a climate in which the rate of change is often constrained or impeded. This climate has caused the life of past investments generally to be longer than would have been the case under less constrained conditions. To the extent that new regulatory developments, public policies, and labor practices free the industry from these impediments, they will also accelerate the process of change and adaptation in the future. 


\section{THIS PAGE \\ WAS INTENTIONALLY \\ LEFT BLANK}


IV THE FREIGHT RAILROAD SYSTEM

The freight railroad system in the United States functions to move carloads of freight from shipper to consignee. In this chapter a general description of the freight service will be presented, together with a description of the railroad system, railroad equipment employed, and a description of the industry.

\section{Freight Services}

\section{Freight Train Makeup}

The following description of the services performed for the customer is based on an SRI report (Ref. 10). The process begins when a shipper places an order with a freight agent for a certain type of freight car. On receiving that order, railroad personnel locate and select an available car that will meet the shipper's requirements. Empty cars may be stored on sidings, in other yards, or at storage locations. After being inspected to ensure that it meets the shipper's needs and is in good mechanical condition, the car is delivered to the shipper's loading facilities by an industrial switch engine crew whose function is to distribute groups of cars from a yard to the various industries located within a specific area.

The industrial switch engine crew generally delivers the cars in one of two ways. The car may be placed on public team tracks where the shipper is given access to load his goods, or it may be placed on private loading sidings beside the shipper's establishment. Since the team tracks are usually on railroad property, the shipper must truck his shipment to the team track together with fork lift or other loading equipment. Since there are usually no storage facilities at the team track, the user must lock all materials and equipment in the car or carry them back to his plant if the loading is discontinued overnight.

After the car has been placed on the appropriate team track or industrial siding, the shipper is given a certain amount of time to load the car. He is charged a demurrage fee for the amount of time required over an allotted period of "free time." The shipper then notifies the railroad that the car is loaded and is ready to be picked up. The loaded car, along with others, is picked up by an industrial switch engine; the cars may be taken to an industry yard where they are accumulated until they are picked up by a local train or until 
enough of them have been gathered to make up a drag of cars to a larger classification yard. At times, instead of being taken to an industry yard, they may be delivered by the industrial switch engine directly to a classification yard.

At the classification yard, the car is sorted along with others into a group of cars called a block, consisting of cars whose next destination is generally similar. These blocks are then assembled into trains that travel to other yards. At such yards, the train makeup may be modified by setting off cars, picking up additional ones, or completely resorting to make up other trains. A car, therefore, may actually travel on a number of trains and be processed through many intermediate yards before reaching the final classification yard.

After reaching the final classification yard, the train on which the car has been traveling is usually disassembled, and the cars are sorted according to the industrial areas to which they are to be distributed. Some cars may be delivered directly to the appropriate Industrial sidings or team tracks for unloading. Others, however, may first be transferred to an industry yard, from which industrial switch engines will deliver them to the consignee's unloading tracks. After receiving a loaded car, the consignee has a certain period of free time in which to unload and then notify the railroad that the car is available for other uses. If this period of free time is exceeded, the railroads are entitled to charge a demurrage fee. After the car has been unloaded and released to the railroad, it may be distributed to other locations requiring empty freight cars or it may be stored until a need arises. If the car belongs to another railroad, it will be sent back to that railroad even if it has not yet been loaded.

There are many variations to this basic process, for example, unit trains, "piggyback" service, and container service.

\section{Unit Trains}

Unit trains consist of a trainset of locomotives and cars that are dedicated to service between two specified points and serve a single customer. Most commonly, the unit trains serve utility customers who move coal from mining areas to their generating plant sites. Other unit trains serve between grain elevators and flour mills or ports. Minor users of unit train service include shippers of sand and gravel, ores, and other bulk commodities. Because of the dedication of the equipment to a single user, unit trains are most frequently loaded in only one direction of travel, returning empty for another load. However, the railroad can, for two reasons, offer a lower cost for unit movement and still realize a profit. First it is not necessary to classify or sort the cars in a switchyard as they are all going to the same destination. 
Second, the cars make a higher number of annual trips, since the service is sold over an extended period of time and the railroad does not have to keep cars available to serve possible, but not realized, demand. Some cars used on unit coal trains are equipped with coupling devices that allow a car to be inverted in a rotary dumper without being disconnected from adjoining cars. Other cars used in unit trains are equipped with discharge ports on the underside that allow dumping of the load without disconnecting the car from the train. These provisions speed the unloading of the train and make it available to carry greater annual loads.

\section{Trailer on Flatcar}

Another service offered is the carrying of highway trailers on railroad cars. Since the highway vehicle rides on top of the railroad flat car, the operation is sometimes called "piggybacking." The technical name for the service is trailer on flatcar, whose initials, TOFC (pronounced toff-sie) are also used to refer to the service. The loading of a trailer on a railcar eliminates a transfer of individual items of a load from the trailer to a railcar, as would he required if the shipper utilized team tracks to load or unload his shipment; thus shippers without rail sidings have access to railroad service via TOFC. From the railroad standpoint, the assembly of highway vehicles at a railroad piggyback yard may reduce terminal charges, because industrial "drags" are often only a few cars, yet a full crew and locomotive may be.used, and crowded terminal conditions may make utilization of equipment very low. A number of plans are available to shippers using piggyback service. Differences in plans result from ownership of the trailer by railroad or shipper, transportation of the trailer over the highway by railroad or shipper, and so on. Some railroads offer premium, high-speed through service for trailers, while on others traffic is carried as carload freight, being switched in yards, and encountering concommitant delays. Unloading of the trailer in high-volume yards is accomplished by straddle cranes that lift the trailer from the top and place it beside the track, or by high capacity forklift trucks that pick up the trailer from the side and position it for coupling with a tractor. In stations that do not have the volume necessary to justify investment in these cranes or stackers, a built-up ramp is provided in such a way that the trailer can be moved on or off the flatcar by its tractor. Decking between cars allows transit of the trailers for several railroad cars to be loaded at one location. 


\section{Container on Flatcar}

Similar to the piggyback service is the container service, COFC. A container is a box that can be carried by highway vehicle, railroad, or ship and offers shippers the opportunity of transferring shipments between these modes without exposing the shipment to loss, damage, or pilferage. Containers must meet highway transport requirements with respect to size and weight, so are limited to 8 feet in width. Lengths of $20,27,40$, and several other sizes are commonly used. For highway transport, a bogie consisting of an underframe and a set of wheels, convert the container into a vehicle that resembles an ordinary highway trailer. The advantages of the container are that the weight of the wheels and tires does not have to be carried, and the flat car can be made lighter because a deck does have to be supplied to roll the car over. Tie-down of the unit is easier for COFC than TOFC, and the absence of wheels creates a load that has a lower center of gravity and less air resistance. Loading and unloading are accomplished with equipment similar to that used in TOFC; however, the drive-on option is obviously not available. The containers must be routed to a location that has facilities for unloading the boxes and has a supply of bogies. Such locations are less common than trailer loading ramps or railroad yards, hence container service is more limited in points served than are other forms of rail transport.

\section{The Freight Railroad Industry}

Intercity freight service by railroad is provided hy 733 rompanies that are, with one exception, privately owned and operated. For statistical and reporting purposes, railroads are usually classified according to revenue: in past years those railroads with annual revenues of $\$ 5$ million or more were defined as Class I railroads; those with annual revenues less than $\$ 5$ million were $\mathrm{Class}$ II railroads. In 1974, there were 74 Class I linehaul railroads, 29 Class I terminal and switching companies, 258 Class II linehaul railroads, and 136 Class II switching and terminal companies (Ref. 11). The Class I linehaul carriers accounted for $99 \%$ of the revenues, and 94 cents of the Class I railroad dollar is earned by the 15 largest railroads (Ref. 12).

Beginning on 1 January 1976 the requirement for Class I railroads was ralsed to $\$ 10$ million in annual revenues. This increase, together with the consolidation of six bankrupt northeast raj.1roads into the ConRail system, left $60 \mathrm{Class} I$ linehaul railroads and $27 \mathrm{Class} I$ switching and terminal companies (Ref. 13). 
In 1974, the latest year for which complete data are available, Class I railroads in the United States carried 851 billion ton-miles of revenue freight, with an originated tonnage of about 1.5 billion tons. Carloadings for 1974 were about 26 million. Coal was the largest single revenue producer for the railroads and accounted for the greatest number of tons, ton-miles, and carloadings. Relative contributions of other commodities to these statistics are shown by Figure 4 .

Railroad employment in 1973 was 520,153 , about one-third the number in the post-World War II years. Total wages were just over \$7 billion, nearly twice the 1945 level. By 1975, employment had declined to 487,789 because of the recession in business, but total wages climbed to $\$ 7.4$ billion.

\section{Physical Facilities of the Freight Railroad System}

To provide the transportation services that it renders, the railroad industry in the United States (including Alaska but not Hawaii and territorial possessions) uses assets with a book value of over $\$ 16$ billion in 1973. The assets include primarily roadway, switchyards, locomotives, freight cars, signal and communications equipment, and other assets, including highway vehicles and trailers, work trains and maintenance equipment, maintenance and repair facilities and buildings, and structures to house the personnel and equipment.

\section{Roadway Mileage}

By the end of 1975, the railroad network contained just over 200,000 miles of roadway in the coterminous (48) United States. Interchange with Canadian and Mexican railroads provides a shipper with direct rail access to virtually the entire North American continent. A major reduction of the system further occurred on April 1, 1976, when ConRail, a new establishment made up of the remains of six bankrupt northeastern railroads, went into operation. At that date, approximately 7,000 miles of railroad were abandoned by ConRail, but about 2,500 miles continued in operation under state or local subsidy, with federal assistance to ease the transition. Thus, at this time, there are about 195,000 miles of roadway. Table 2 shows the approximate distribution of single and multiple trackage over the roadway and the traffic densities over each track configuration.

It can be seen from the table that approximately $60 \%$ of the track mileage carries less than 10 million gross ton-miles per mile annually. In fact about $67 \%$ of the total freight traffic is carried on $20 \%$ of the route miles (Ref. 14). 


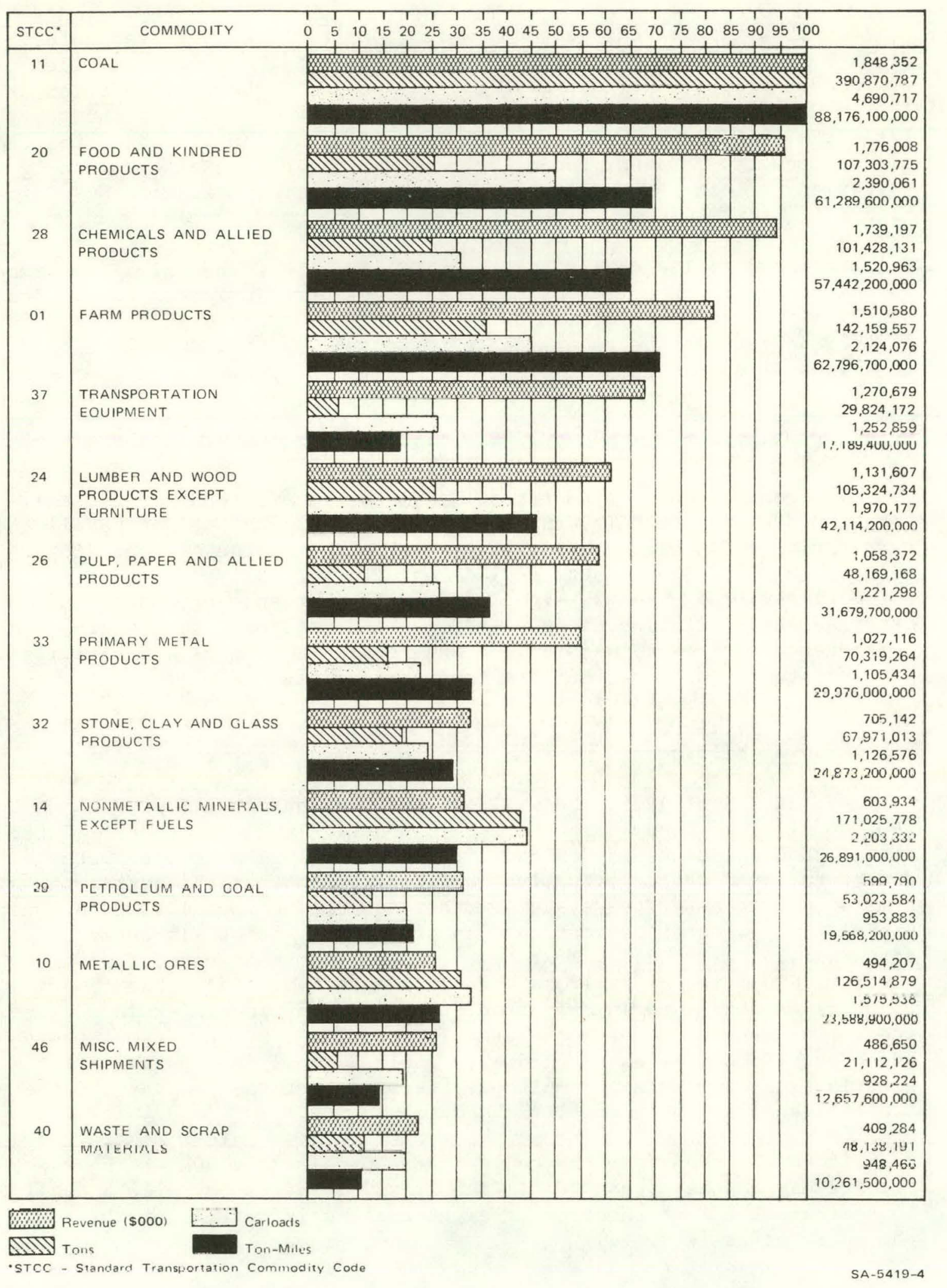

FIGURE 4 DISTRIBUTION OF FREIGHT REVENUE, TONNAGE, CARLOADS, AND TON-MILES, YEAR 1974 
Table 2

MILES OF SINGLE- AND MULTIPLE-TRACK

RAILROAD BY TRAFFIC DENSITY

\begin{tabular}{ccccc}
$\begin{array}{c}\text { Range of Annual } \\
\text { Density } \\
\text { (millions }\end{array}$ & \multicolumn{3}{c}{ Track Configuration } & \\
$\begin{array}{c}\text { of gross ton- } \\
\text { miles per mile) }\end{array}$ & 1 & 2 & 3 & 4 or more \\
0.0 & 7,479 & 77 & -- & -- \\
$0.0-0.99$ & 48,693 & 391 & -- & -- \\
$1.0-4.99$ & 45,653 & 775 & -- & -- \\
$5.0-9.99$ & 26,982 & 954 & 26 & -- \\
$10.0-19.99$ & 27,674 & 3,156 & 50 & 37 \\
$20.0-29.99$ & 12,206 & 3,980 & 40 & 32 \\
$30.0-39.99$ & 4,696 & 3,705 & 45 & 45 \\
Over 40 & 2,574 & 5,590 & 280 & 175 \\
Unknown & 11,568 & -748 & 13 & 277 \\
TOTAL & 187,525 & 19,376 & 454 & 566
\end{tabular}

Source: (Ref. 15). 
Railroad Network

Roadway classification schemes usually divide railroad lines into two categories: main line and branch line. For purposes of this study, branch lines are considered to be those portions carrying less than 10 million gross ton-miles per mile of traffic. Main lines carry a greater amount of traffic. Detailed maps of the entire U. S. railroad network (main line and branch line) are available. An atlas of this type can be extensive. The Transportation Zone Maps (Ref. 16) for example, cover the continental United States with a series of some 500 maps. For purpose of this study it was determined that a data base containing only the main line track would be most feasible to obtain. The reader is referred to the zone maps or other classifications such as that contained in a recent DoT release (Ref. 14) if more detail is required.

It was seen in the preceding section that a reasonable description of the U.S. railroad network in terms of traffic carried can be obtained by considering approximately $20 \%$ of the route miles. The following description covers that main line railroad network and the data base which has resulted from concentration upon that heavily traveled portion of the country's railroad system. The development of the network is described in Appendix A.

Figure 5 is a map of the right-of-way that has been included in the data base. The network consists of 56,389 miles of roadway, or about $28 \%$ of the route miles in the country. Approximately 1350 billion gross ton-miles of freight were hauled in 1973 over this network. Based upon calculations described in appendix $\Lambda$, this network. carried an estimated $65 \%$ of the total gross ton-miles reported in 1974 .

In addition to the geographic description (mileage and locations) shown in Figure 5, the data base includes the company designations for ownershlp of each portion of the road, and profile information in terms of elevation along each segment. The entire network has been coded and is available for computer processing.

\section{Switchyards}

Switchyards serve several purposes in the operation of the railroad network, but the primary ones are sorting and temporary storage. The surting function is performed to group cars bound for common destinations and to place cars in proper order within a train. The groups of cars thus formed are called blocks, and move to their common destination as a unit; this common destinatinn may he annther switchyard, where the cars in the block are resorted to form new groups. 


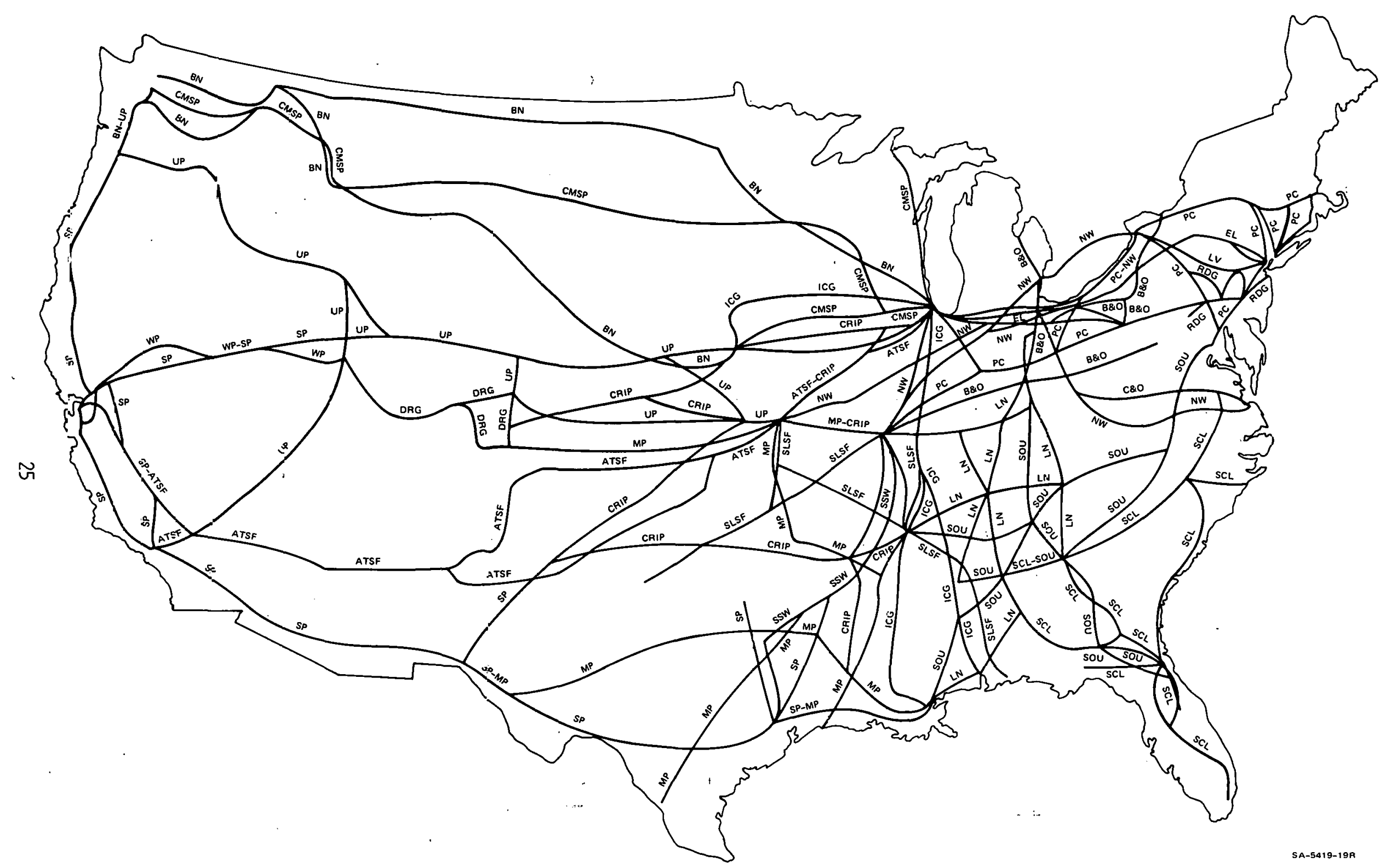

FIGURE 5 MAP OF UNITED STATES RIGHT OF WAY 
THIS PAGE

\section{WAS INTENTIONALLY LEFT BLANK}


Once grouped together, the block is handled as a unit, without uncoupling of individual cars, until it reaches its destination. Several blocks are coupled together to make a through or road train, which may then set out and pick up blocks at intermediate yards along its route. For way trains that serve individual customers along their route, the cars are placed on the trail in "station order," that permits uncoupling the first car in the train from the remainder, maneuvering it into a siding, and recoupling the locomotive to the remaining cars in the train. The storage function accumulates cars at certain points after they are sorted until there are sufficient cars to make a train of economical length.

Other functions performed at the yard include weighing of cars to determine charges and repair and servicing of cars and locomotives. Speciallzed switchyards serve trailer and container traffic and passenger trains, or provide long-term storage for unused equipment.

There are two types of switchyards operated in the United States-flat switching yards and hump yards. A flat yard generally consists of a series of tracks connected by a ladder track and switching lead, as shown in Figure 6. Most flat yards use the same tracks for receiving, classifying, and dispatching trains, although many such yards do have separate receiving and/or departure tracks. The car-sorting process requires that a group of cars be pulled out to the switch lead where the switch engine will accelerate quickly toward the yard and then decelerate. Just prior to deceleration, a car or group of cars will be uncoupled and the deceleration of the switch engine and the cars coupled to it will cause one or more of the uncoupled cars to separate from the rest. This procedure is called giving the cars a "kick." The

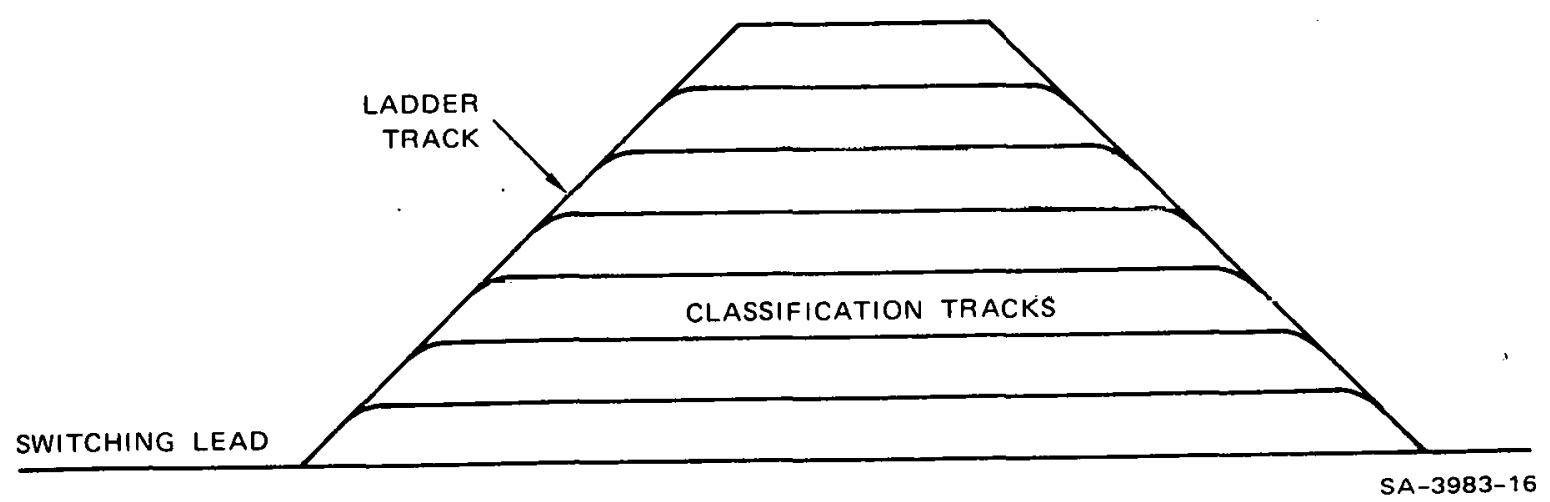

FIGURE $G$ TYPICAL FLAT-YARD TRACK CONFIGURATION 
switch engine generally continues kicking cars toward the classification tracks until reaching the ladder track, at which point it will pull the remaining cars back along the switch lead and resume the process. The cars and groups of cars that have leell klcked will travel along the switch lead and ladder track until being switched onto the appropriate classification track. Switches in most flat yards are generally manually thrown. To improve operations, flat yards are often somewhat saucer-shaped so that the cars will tend to accumulate in the center of the yard. Such gradients also reduce the frequency of cars stopping short on the switch lead, ladder track, or classification track (Ref, 10).

Additional capacity for the flat switching yard is provided by adding switch engines, by adding length to the classification tracks, and by adding classification tracks. Adding additional classification tracks enables the yard to make up more groups of cars, while longer tracks allow more cars in a group. Adding switch engines speeds up the classitication and handling of cars. However, the amount of additional capacity that can be achieved by addiun switch engines is limited by interference. Interferences occur when two switch engines must access the same track, or where one occupies a junction that the other must cross. Interference also occurs when mainline trains enter the yard, blocking acress to the rcceiving tracks or blocking junctions that the switch engines must cross. For these reasons, adding switch engines increases capacity of the yard at a diminishing rate, so that approximately four engines will produce the maximum amount of work that can be expected from the yard.

To classify more cars at a single location, a different type of yard must be used, the gravity, or hump yard.

Hump yards are used to claesify more efficicntly a laige number of cars. The geometric characteristirs and typicaliy large volume throughput of most hump yards dirtate that ocparate subydido bc construcled for receiving, classifying, and dispatching trains. A typical arrangement of these subyards is illustrated in Figure \%. Generally, an inbound train is placed on one of the tracks in the receiving yard, and certain operations (such as inspecting the rars' mechanical systeuls dud bleeding the air from the hrakes) are pcrformet. The car-sorting process requires a switch engine to push a group of cars to be sorted along the hump lead and over a raised portion of trackagc called the hump crest. Cars are uncoupled just prior to reaching the hump crest and begin to ascelerate down the incline on the other side of the hump crest, thereby separating from the ewitch engine and remaining cars. The crest of the hump is 12 to 20 feet above the level of the classification tracks. As can be seen in Figure 8, the geometric track pattern of the classification tracks differs significantly from that of 


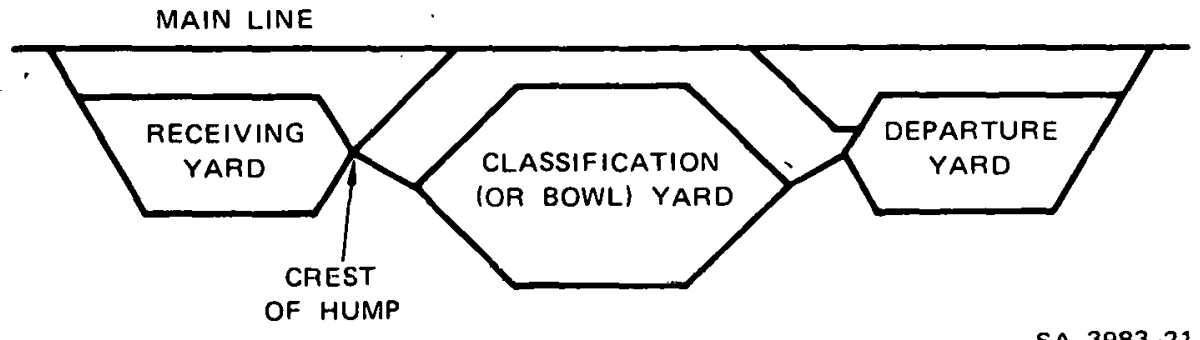

FIGURE 7 A TYPICAL ARRANGEMENT OF SUBYARDS IN A HUMP YARD

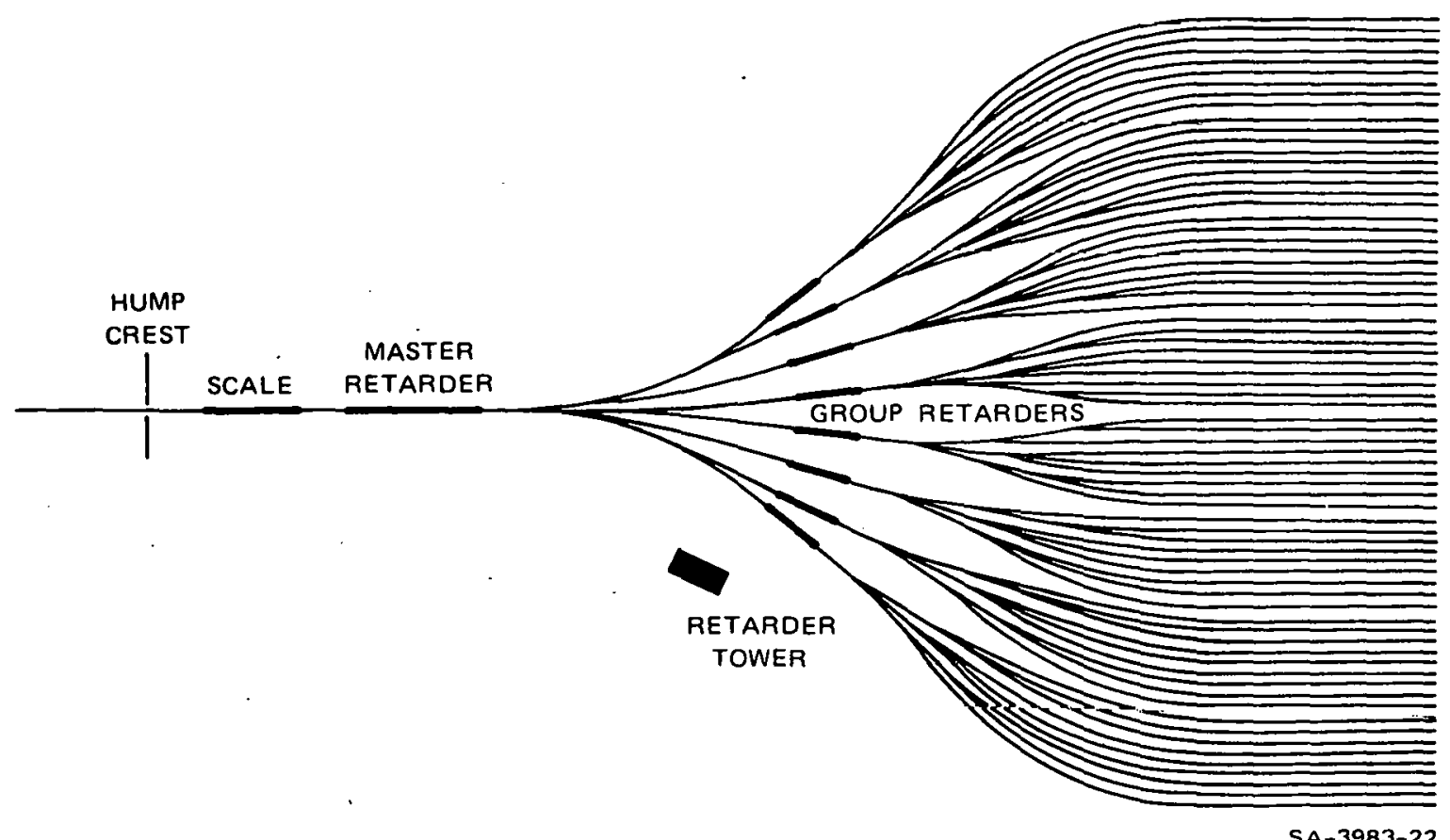

FIGURE 8 GEOMETRIC PATTERN OF CLASSIFICATION TRACKS IN A HUMP YARD

1 
flat yards. In the hump yard, instead of all tracks being connected to the ladder track, the classification tracks generally consist of gruups of six to nine individual tracks. These are connectcd by individual leads to the main hump 1ead. This pattern is used because it requires fewer retarders for speed control and reduces the frequency of catch-ips.

As part of a study of railroad classification yard technology, an inventory of all U. S. switchyards was compiled from lists of facilities under the surveillance of Federal Railroad Administration Safety Inspectors (Table 3). Yard ownership, location, and functions were identified.

Four functional yard groups were developed for the inventory. The first two included all yards that perform classification work (yards that sort and group outgoing cars into the correct b.locks for road-haul trains, assemble outbound road-haul trains, and/or disassemble inbound road-hal trains). These yards were further grouped acuording to whether the locàl and industrial distrihution and collection work compl lses d significant portion of their function. As a result, these facilitics were categorized as "classification/industrial" yarde if thcy were used to:

- Sort inbound cars into groups that were then distributed to local industrles or to industrial or interchange yards.

- Collect and/or receive cars from local industries or from industrial and interchange yards.

Yards that did not perform a significant amount of this industrial distribution work were categorized as "classifiçation" yards, 1,sed principally for resorting and reblocking cars and groups of cars received from inbound road-haul trains and then reassembling them into outbound road-hanl trains.

The other two groups were composed of rhnse yards that arc used primarlly for local switching associated with the collection and distribution of freight cars. These were categorized as "industrial" yards if they were worked by at least one assigned switcher or by road switchers whose total time spent working the yard avcraged one or muit tricks per day. Those worked by road switchers leas than one trick per' day were categorized as "small industrial" yards. There is no largescale classification activity involving the makeup or breakup of road-haul trains in these yards. 
Table 3

SUMMARY OF YARD INVENTORY

\section{Inventory}

Flat yards

Hump yards

Total Number of Yards in $\stackrel{\omega}{\longmapsto}$

\begin{abstract}
Class./Indus.

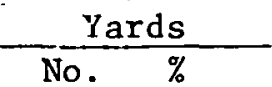

$930 \quad 90$

$98 \quad 10$
\end{abstract}

1028

$\begin{array}{rr}\begin{array}{c}\text { Classification } \\ \text { Yards }\end{array} \\ \text { No. } & \% \\ 183 & 91 \\ 18 & 9\end{array}$

201

\begin{tabular}{rr}
\multicolumn{2}{l}{$\begin{array}{l}\text { Industrial } \\
\text { Yards }\end{array}$} \\
\hline No. & $\%$ \\
1381 & 99 \\
8 & 1
\end{tabular}

1389
Small Indus.

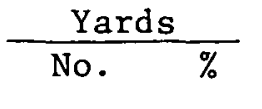

$\frac{\text { A1l Yards }}{\%}$

$1551 \quad 100$

$4045 \quad 97$

$0 \quad 0$

1243

Source: Ref. 10. 
At the end of 1973, railroads in the United States owned 29,926 locomotive units. (Ref. 12). The distribution by type of power is as follows:

$$
\begin{array}{lr}
\text { Diesel-electric } & 29,419 \\
\text { Electric } & 243 \\
\text { Other and auxiliary } & 264 \\
\hline \text { Total units } & 29,926
\end{array}
$$

The list graphically demonstrates the preference of railroads for diesel power. The advantage of the units is their dependability, with a typical locomotive being available for service $90 \%$ of the hours of Llie yedr.

The diesel-electric locomotive uses a diesel-cycle engine to generate power, which is transmitted to the driving wheels by an electrical generator and electric traction motors. In newer models, an ac generator, or alternator, is used to help reduce maintenance by eliminating the commutator and brushes used on a dc generator. The alternating current is rectified by solid-state units to produce direct current for the series-wound de traction motors.

About $90 \%$ of the electric locomotives are used by passenger and commuter railroads in the northeast--AMTRAK, the Long Island, Penn Central, and similar operations-with a number of the remainder being used in electrified commuter operations around Chicago. Two types of electric locomotives are used, differing in the way they draw current. Some draw energy from a wayside "third rails" by means of sliding contacts, with a return circuit through the grounded rails. E1ectrir. traction motors on the locomotive axles prnpel the locomotive.

Alternatively, power may be obtained from a wire called a catenary (a nonflexible filament under tension and supported at two points), mounted over the train. Again, grounding is through the rails, and a mechanism, mounted on the locomotive and called a panograph, is used to hold a sliding contact against the catenary. The plertric locomotive 1s rugged and durable, because the prime mover is in a stationary power plant and the electric machinery is highly developed. However, the cost of installing the third rail or catenary, together with the attendant power distribution system, has limited the use of electrified railroad.

The principal manufacturers of locomotives in the United States are the Electromotive Division of General Motors Corporation and the transportation business division of General Electric Corporation. 
The Alco Division of White Motors also produces some units. Other producers in the past have been Baldwin-Lima-Hamilton, and Fairbanks-Morse, although these are not manufacturing locomotives at this time. A tabulation of locomotives in service, by horsepower and manufacturer, is presented in Table 4.

Information obtained from the principal U. S. suppliers, Electromotive, Division of General Motors Corporation and General Electric Corporation, for their total production of locomotives by type is presented in Table 5 .

In addition, personnel at Electromotive Division conductéd a survey of $26 \mathrm{Class} I$ railroads to determine the number and type of 1ocomotives in service as of 1 January 1976. The results are presented in Table 6. Note that there were 74 Class I rallrodds on that date, so that the 1ist, while constituting a large sample, is incomplete.

Despite the fact that locomotive manufacture is highly standardized, with each manufacturer producing only a limited number of models, many modifications and much optional equipment are installed on locomotives. Such modifications as special location of air intake to avoid inhalation of exhaust-contaminated air while in tunnels limit the complete interchangeability of units. Even such apparently minor features as. the tone of the warning whistle can hinder interchangeability, as whistle tones have reportedly been responsible for a few grade crossing accidents, where motorists failed to recognize the tone of the whistle of a locomotive operating outside its territory.

\section{$\underline{\text { Railroad Cars }}$} States:

Five primary types of rail cars carry freight in the United

- Box: Enclosed on all sides and with a closing and lockable door

- Flat: Having no sides or top, with provision for securing loar

- Gondola: Having enclosed sides and open top, for transport of bulk commodities such as sand, ore, and coal

- Hopper: Enclosed on all sides, with open or closed top and doors in bottom which can be opened to deliver lading by gravity

- Tank: Ueed for liquids with provision for filling and discharging 
Table 4

ESTIMATED POPULATION OF LOCOMOTIVES BY HORSEPOWER AND MANUFACTURER

\begin{tabular}{|c|c|c|c|c|c|c|c|}
\hline \multirow[b]{2}{*}{$\begin{array}{l}\text { Horse- } \\
\text { power }\end{array}$} & \multicolumn{6}{|c|}{ MánuFaclurer } & \multirow[b]{2}{*}{ Total } \\
\hline & $\begin{array}{c}\text { Electro- } \\
\text { motive } \\
\text { Division } \\
\end{array}$ & Alco & $\begin{array}{l}\text { General } \\
\text { Electric }\end{array}$ & $\begin{array}{c}\text { Baldwin- } \\
\text { Lima- } \\
\text { Hamilton }\end{array}$ & $\begin{array}{l}\text { Fairbanks- } \\
\text { Morse } \\
\end{array}$ & Unknown & \\
\hline 5,000 & 47 & 0 & 0 & 0 & 0 & 0 & 47 \\
\hline 4,200 & 45 & 0 & 60 & 0 & 0 & 0 & 105 \\
\hline 4,000 & 6 & 0 & 185 & 0 & 0 & 0 & 191 \\
\hline 3,600 & 1,646 & 31 & 171 & 0 & 0 & 0 & 1,848 \\
\hline 3,300 & 0 & 0 & 52.2 & 0 & 0 & 0 & 522 \\
\hline 3,000 & 2,720 & 86 & 677 & 0 & 0 & 0 & 3,483 \\
\hline 2,800 & 0 & 21 & 211 & 0 & 0 & 0 & 238 \\
\hline 2,750 & 0 & 78 & .5 & 0 & 0 & 0 & 83 \\
\hline 2,700 & 29 & 26 & 0 & 0 & 0 & 0 & 55 \\
\hline 2,500 & 1,604 & 84 & 559 & 0 & 0 & 0 & 2.247 \\
\hline 2,400 & 288 & 113 & 0 & 0 & 20 & 0 & 421 \\
\hline 2,350 & 0 & 0 & 0 & 0 & 6 & 0 & 6 \\
\hline 2,300 & 95 & 0 & 0 & 0 & 0 & 0 & 95 \\
\hline 2,250 & 1,196 & 0 & 317 & 0 & 0 & 0 & 1,513 \\
\hline $2.00 \Omega$ & $2,1 \cap ?$ & \pm 63 & 0 & 14 & 0 & $u$ & 2,281 \\
\hline 1,850 & 219 & 0 & 0 & 0 & 0 & 0 & 219 \\
\hline 1,800 & 951 & 385 & 56 & 0 & 0 & $n$ & 1,392 \\
\hline 1,750 & 3,300 & 0 & 0 & 2 & 0 & 0 & 3,302 \\
\hline 1,600 & 47 & 591 & 0 & 33 & 47 & 3 & 721 \\
\hline 1,500 & 4,637 & 116 & 34 & 5 & 0 & 14 & 4,806 \\
\hline 1,400 & 20 & 4 & $U$ & 0 & $n$ & 0 & 24 \\
\hline 1,350 & 18 & 0 & 0 & 0 & 0 & 0 & 18 \\
\hline 1,300 & 13 & 0 & 0 & 0 & 0 & 0 & 13 \\
\hline 1,200 & 2,026 & 86 & 0 & 151 & 138 & 13 & 2,415 \\
\hline 1,000 & 1,080 & 888 & 0 & 113 & 24 & 29 & 2,137 \\
\hline 700 & 889 & 142 & 170 & 2.3 & 0 & 38 & 1,263 \\
\hline TOTAL & 22,978 & 2,820 & 2,967 & 341 & 235 & 97 & 29,445 \\
\hline
\end{tabular}

Source: Compiled by SRI, from Ref. 17. 
Table 5

PRODUCTION OF LOCOMOTIVES BY TYPE BY ELECTROMOTIVE DIVISION (EMD) OF GENERAL MOTORS AND GENERAL ELECTRIC (GE) TO 1 JANUARY 1976

$\begin{array}{llcc}\text { Manufacturer and Type } & & \text { Rated Horsepower } & \\ \text { EMD } & \text { GP-38-2 } & 2,000 & 1,134 \\ \text { EMD } & \text { GP-40-2 } & 3,000 & 261 \\ \text { EMD } & \text { SD-40-2 } & 3,000 & 989 \\ \text { EMD } & \text { SD-45-2 } & 3,600 & 383 \\ \text { GE } & \text { U18 } & 1,800 & 117 \\ \text { GE } & \text { U23 } & 2,250 & 433 \\ \text { GE } & \text { U25 } & 2,500 & 594 \\ \text { GE } & \text { U28 } & 2,800 & 220 \\ \text { GE } & \text { U30 } & 3,000 & 897 \\ \text { GE } & \text { U33 } & 3,300 & 477 \\ \text { GE } & \text { U36 } & 3,600 & 245\end{array}$

Source: Correspondence with GM and GE personnel 
Table 6

EMD LOCOMOTIVES IN SERVTCE FOR 26 CLASS I RAILROAD COMPANIES

ON 1. .TANUARY 1976

Mode1

Road Units

F-3

F-7/FP-7

F-9

GP-7

GP-9

$\mathrm{GP}-18 / 28$

GP-20

GP-30

GP-35

GP $-38 / 38 \mathrm{AC}$

GP-39

CD -10

SD-7

SD-9/18/28

SD-24

SD- 35

SDP- 35

SD- 38

SD- 39

SD-40/SDP-40

SD-45/F-45/SDP-45/FP-45

SD-45-X

DD- 35

DDA-40-X

GP-38-2

GP-39-2

GP-40-2

SD-38-2

SD-40-2

$S D-45-2$

MP-15/15AC

Total, road units

Switching Units

BL $1 / 2$

TR $1 / 2 / 3 / 4 / 5 / 6 / 9 / 12$

NW

SW1, 2, 3

SW600

SW7

EW

SW900

SW9

SW1000

SW 1200

SW 1500

Total, switching units
Nomina $1 \mathrm{HP}$

1,500

1,500

1,750

1,500

1,750

1,800

2,000

2,250

2,500

2,000

2,300

$7, \mathrm{n} \cap \mathrm{n}$

1,500

$1,750 / 1,800 / 1,800$

2,400

2,500

2,500

2,000

2,300

3,000

3,600

4,200

5,000

$6,6 \cap 0$

2,000

2,300

3,000

2,000

3,000

3,600

1,500

$$
\begin{gathered}
1,500 \\
1,800-2,400 \\
y 00-1,000 \\
600 \\
600 \\
1,200 \\
800 \\
900 \\
1,200 \\
1,000 \\
1,200 \\
1,500
\end{gathered}
$$

No. in Service

141

870

219

2,264

3,348

313

245

893

1,144

854

20

1,135

178

393

215

368

10

35

55

837

1,395

6

45

16

965

69

206

21

963

303

184

$\overline{17,820}$

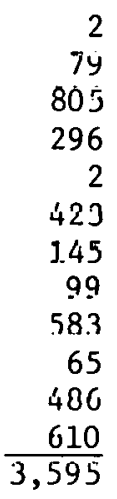

Source: Correspondence with Company personnel 
Other specialized cars range from drop-center cars for carrying large, heavy machinery to automobile racks to refrigerator cars for produce carriage. The variations of the basic types are also many: specialized modifications, flatcars for container or trailer transport, different kinds of hoppers, and box cars with interior fittings to provide longitudinal support and avoid lading damage.

Because cars must be usable throughout the country, standards exist for the design and location of couplers, cross sectional dimensions of the car, length of the car, and maximum weight and wheel loading. In some cases, longer, heavier, or wider cars are used, but their routing is carefully planned to avoid interference with adjacent structures, overhead clearances, tunnels, curves, or bridges that would restrict the movement of the car.

Many cars are highly specialized, such as those designed to carry coils of steel; these have a built-in supporting structure to prevent misalignment of the coil. Other cars have multiple walls, which provide insulation for carrying hot or cold materials at relatively constant temperatures. Because of the specialized configuration of these cars, their typical duty cycle is to be loaded in one direction and empty for the return trip.

Freight cars are owned by railroad operating companies, customers, car leasing companies, and specialized companies such as the Trailer Train Company, which is owned by a group of railroads and supplies flatcars for automobile transport. Cars owned by private shippers are seldom loaded for the return trip, so that the duty cycle of these cars almost always shows an empty return. The tabulation below shows the number of railroad-owned cars by type and the number of cars owned by other than railroad operating companies, not broken down by type, at the end of 1973 (Ref. 12 and 18).

$\begin{array}{lr}\begin{array}{l}\text { Railroad } \\ \text { Box, all types }\end{array} & 558,438 \\ \text { Flat, all types } & 91,703 \\ \text { Hopper, all types } & 509,598 \\ \text { Gondola } & 187,851 \\ \text { Tank } & 3,233 \\ \begin{array}{l}\text { Other (includes } \\ \text { ballast, dump, and } \\ \text { some specialized } \\ \text { cars) }\end{array} \\ \begin{array}{l}\text { Sublutal } \\ \text { 1, } 418,219\end{array}\end{array}$


Private leasing company

Shippers, and others 292,440

Total cars $\quad 1,710,659$

The cost of freight shipment and the energy used per ton of freight shipped can be reduced if the cars can move loaded in both directions of a trip. The more specialized the car, the less likely 1 t is that it will return loaded (Table 7). Units in special service require immediate return to the originator, and thus higher ratios of empty miles result than in the case of general service equipment.

Table 7

RATIO OF EMPTY TO LOADED CAR MILES

Car Type

Box

Flat

Gondola

Hopper, open

Hopper, covered

Tank

Refrigerated

Sunree: Ref. 19

Train Control (Signaling)
Geiles al 3elv liee
(range)

$$
0.65-0.76
$$

$0.88-0.89$

$0.78-0.83$

$0.86-1.04$

Not reported

$1.08-1.10$

$0.70-1.30$ $\frac{\begin{array}{c}\text { Special Sérvice } \\ \text { (range) }\end{array}}{}$

$0.96-1.01$

Not reported

$1.00-1.01$

$0.99-1.02$

$1.01-1.20$

Not reported

Not reported

Control of train traffic emplnys threp hasir systems, in ordor of Increasing sophistication: train orders and time tables, automatic block signal control, and centralized traffic control.

\section{$\underline{\text { Train Orders }}$}

On relatively lightly traveled railroad lines, movements are controlled by a system of train orders, whereby a dispatcher gives written or telegraphed permission to the conductor of a train to proceed from where he is to some other point, where he will await further orders or until certain conditions are met. For example, on a 
single-track line, a train might be given orders to proceed to a designated siding and wait for an oncoming train to clear the siding, then proceed to a designated terminal location. The system was originally designed to utilize the trackside telegraph services, and thus is coupled to slow communications.

A form of the train order is the time table, a schedule which provides the basic authorization to proceed. Time tables are established with sufficient headway so that if the schedule is disrupted, following trains can be contacted and given temporary orders.

\section{Automatic Block System Control}

With automatic block system control (ABS), the track is divided into sections called blocks. The length of a block depends on the weight, length, and speed of trains expected to be using the track, varying from tens of miles in rural areas where freight traffic predominates to hundreds of feet in urban transit systems. Circuits sense the presence of a train in a block, and, if a block is occupied, a red signal lamp shows at the entrance to the block. Following trains are prohibited by rules from entering the block guarded by a red signal. As the leading train enters the succeeding block, the signal at the entrance to the block just left will change from red to yellow, and the following train is permitted to enter the block at reduced speed so that it can stop in the distance available. In the basic system, when no train occupies the next two blocks, the signal shows green, indicating that a train entering the block may proceed at maximum permissible speed over the block. More refined systems, applicable where there are both fast and slow trains, will include a fourth signal--usually a flashing yellow--that shows occupancy of the third block away, giving further warning of potential hazards and more room for braking. An intermediate speed is usually permitted on the flashing yellow signal.

The automatic block signals have been developed over a long period of time and have evolved into reliable systems, which are located at trackside and need no human supervision. Communications needs are minimal, requiring only transmission from the train detector to the signai system.

\section{Centralized Traffic Control}

While the automatic block signaling system is simple and reliable, capacity and flexibility can be increased by injecting human observation and decision making into the systems. Centralized traffic control 
(CTC) increases capacity by allowing closer spacing bctwcen trains than would be possible with fixed block lengths, and greater flexibility in cases where there is crossing or merging traffic.

The centralized traffic control system is designed around a dispatcher who has displays of train locations (indicated by block occupancy) and positions of switches along the route under his control. The dispatcher controls a distance of about 100 miles on a U. S. average. The dispatcher controls movements along the road by radioed instructions. For example, a local train has picked up loaded cars from a customer siding and wants to pull out onto the main line. He requests that the dispatcher set the switch for entry to the main line and give him clearance to proceed to a subsequent checkpoint. The dispatcher will observe other train movements along the route and, when safe to do so, will send a command to position the switch and radio his authorization to proceed. Capac1ty is increased becausc the dispatcher can observe all train movements in the area, he knows the weight and braking capability of the trains, and he can inject judgment into the determination of correct spacing between the traine.

More advanced centralized train control systems use computers to monitor the logic of switch positions, and still higher levels of sophistication make provision for control of the maximum speed of trains from a centralized point so that the operator cannot move his train at a speed greater than that specified for the road conditions.

Automatic block signaling and centralized traffic control help effectively to increase the capacity of existing railroad lines. As signal sophistication increases, from train orders to block signals to centralized traffic control, smaller and smaller headways, or spacings hetween trains, are possible. Thus, the capacity of the railroad increases correspondingly (Table 8). Where capaclty ls lilcieased by centralized traffic control, single track railioad, using CTC, can replace double-track that uses block signals. The reduction in maintenance and the salvage value of the unused rails are significant benefits of such a move.

Table $y$ shows approxlmate mlleages of single and multiple clogs $T$ railroad track controlled by the var iuus signal systems. 
RAILROAD CAPACITY, SINGLE AND DOUBLE TRACK

WITH THE VARIOUS SIGNAL SYSTEMS

\begin{tabular}{|c|c|c|c|}
\hline & $\begin{array}{c}\text { Train Orders and } \\
\text { Time Table } \\
\end{array}$ & $\begin{array}{c}\text { Automatic Block } \\
\text { Signals } \\
\end{array}$ & $\begin{array}{c}\text { Centralized } \\
\text { Traffic Control }\end{array}$ \\
\hline Single track & $\begin{array}{l}15 \text { trains/day } \\
23 \mathrm{MCT}^{*}\end{array}$ & $\begin{array}{l}40 \text { trains/day } \\
62 \mathrm{MGT}\end{array}$ & $\begin{array}{l}60 \text { trains/day } \\
93 \mathrm{MGT}\end{array}$ \\
\hline Double track & No Data & $\begin{array}{c}120 \text { trains/day } \\
186 \mathrm{MGT}\end{array}$ & $\begin{array}{l}160 \text { trains/day } \\
250 \mathrm{MGT}\end{array}$ \\
\hline
\end{tabular}

*Million gross ton-miles/mile annually

Table 9

DISTRIBUTION OF SIGNAL SYSTEMS

FOR CLASS I RAILROADS IN THE UNITED STATES (in miles)

Signal System

Timetable or train orders

Automatic block signals

Centralized traffic cuntrul

Other \& unknown

\section{Single Track}

127,091

26,851

32,221

1,476
Multiple Track

774

12,094

7,771

$-$
Total

127,865

38,945

39,992

1,476

Source: (Ref. 15). 


\section{Communications}

The geographically dispersed operations of railroad companies make communications an essential operational and management tool. Telegraph communications developed alongside the railroads, and the communications system in the right of way is considered a real and significant part of the value of the railroad network. In recent years, however, microwave communications have replaced telephone and telegraph wire lines because of lower maintenance cost and the diminishing number of skilled poletop repairmen. It is estimated that there were 41,000 route miles of microwave in operation or authorized at the end of 1975 (Ref. 13).

Transmission of data is becoming the primary use of railroad communications systems. Small slave computers at points such as switchyards are linked to large units at central locations. With such linkages, progress of freight cars through the system can be monitored and information can be provided to shippers about prospective arrival times and to management about the location and use of empty freight cars. In addition, information about cost and operational control is transferred trom one computer to another in the system. Finally, computers of different railroad companies link together to exchange information about the cars on trains heading for another company's territory.

In addition to long distance communications, radio communication between train and switch crews speeds operations in switchyards. Communication within the train crew is also important, when the conductor in the caboose may be more than a mile behind the locomotive crew but may need to exchange information about transmit operating instructions. For these purposes it is estimated that there were 13,000 radio stations and 160,000 mobile units in operation by railroads or authorized at the end of 1975 (Ref. 13).

\section{Miscellaneous Other Equipment}

Vehicles and related equipment owned by railroads include trailers, containers, bogies, and highway tractors to support piggyback operations; truck to haul equipment and materials; and buses and passenger vehicles to transport personnel to and within work locations. The tabulation below shows the number of vehicles owned by Class I linehaul railroads at the end of 1973 (Ref. 12): 


$\begin{array}{lr}\text { Bogies } & 4,500 \\ \text { Containers } & 4,295 \\ \text { Chassis } & 131 \\ \text { Semi-trailers } & 9,442 \\ \text { Tractors } & 1,038 \\ \text { Trailers } & 14,806 \\ \text { Trucks } & 27,689 \\ \text { Buses } & 294\end{array}$

In addition, several railroad companies own trucking firms because of so-called grandfather rights allowing them to maintain ownership held at the time that legislation prohibited future acquisition of other transportation modes.

The railroads also own specialized work equipment for track maintenance, clearing wrecks and derailments, and hauling materials for the railroad. Track maintenance equipment includes dispensers for herbicides; equipment for ballast plowing, sledding, and clearing; tie removers and replacers; spike removers and drivers; rail surfacing units; and cars that carry rails that are welded into lengths of 1 mile. Cranes and jacks are used to clear and rerail equipment, and specialized cars are used to perform such jobs as carrying and tamping ballast on the roadbed. Some of these specialized pieces of equipment have both rubber tires and steel wheels to permit travel by either highway or railroad.

Large computers operated by 81 railroad companies were estimated to number 249 at the end of 1975 , in addition to smaller units that are used to control switchyards and other processes. Computers are used for accounting, management control information, and keeping track of freight cars in the system (Ref. 13). 
THIS PAGE

\section{WAS INTENTIONALLY LEFT BLANK}




\section{RAILROAD COSTS}

\section{Problems of Analyzing Railroad Costs}

Railroads are among the oldest continuously operating industries in the United States, and their economic importance to the rest of the economy, together with their apparent stability, have made them the subject of numerous attempts to characterize their cost behavior. Regardless of the duration and intensity of these efforts, a completely descriptive model of the industry has thus far escaped the economists. Relative to other industries, the cost pattern of the industry is characterized by large and long-lived investments; even operating costs have a large constant component that indicates a minimum staffing level that does not need to be increased proportionately to meet increases in activity.

There are numerous tradeoffs in the design of a railroad system between number, location, and size of switchyards; connectivity of the rail system; and operational characteristics such as speed, routes, and schedules. These parameters must be established in the face of considerable variation and uncertainty in the level and pattern of traffic movement, making system optimization a very uncertain process. Outside influences such as regulation and bargaining agreements restrict the ability of the system to adapt to changes in traffic patterns. Finally, the interaction of the components makes segregation of the costs of operating a single part of the system very difficult because of the need to allocate the high proportion of those costs that are joint or common among the other parts of the system and services that are in operation.

Analysis of railroad costs is further complicated by the amount and form of cost data collected by the railroads and reported to the Interstate Commerce Commission (ICC). Voluminous financial reports are provided by the railroads to the commission, but individual accounts frequently contain a mixture of wanted and unwanted components, and many arbitrary allocations are present in the preparation of the accounts. For example, maintenance-of-way and structure accounts have subaccounts that divide expenses between yard switching tracks, road switching tracks, and road tracks. However, maintenance-of-way and structure costs are not accumulated in these subaccounts by many railroads, and the ICC allows an allocation of total maintenance expenses in these accounts by a set of factors that allocate the expenses in the following proportions: 


$\begin{array}{lll}\text { First main road track miles } & X & 1.0 \\ \text { Second main road track miles } & X & 0.83 \\ \text { Branchline track miles } & X & 0.49 \\ \begin{array}{l}\text { Yard switching and side } \\ \quad \text { track miles }\end{array} & & \\ & X & 0.32\end{array}$

These weights were determined from a survey conducted by the ICC.

Considering these complications, two approaches to a description of the cost of railroading have been pursued: on a facility and service basis and on a company basis. The facility and servire model is developed to analyze what would happen if technological or operational. changes are made by the railroads. For this purpnse, a modcl is con.structed that is composed of data from surveys and cost analyses by individual railroads, using accounting data reports only where the data are not otherwise available. This model relies on an engincering description of the operations and facilities of a small part of the railroad at one time; hence the opportunity to trade off between relative investments or allocations of resources is limited in this engineered cost methodology. To uvercume the limitation to showing the tradeoff available, we have also developed the company-cost model to analyze the cost of the dependence on volume of railroad operation, given the activity of a management that is operating to allocate resources in a reasonably efficient way.

\section{lost of Rallroad Facilities and Services}

In order to describe the economic impact of changes in railroad technology or operations on the costs of railroad operations, we have developed an engineering model of railrnan coste that ig buill divuud an assumed abstract railroad network and engineering description of the facilities and operations that are involved.

The analysis used studies of particular opcrations that were performed to gain understanding of the rnst of operating certaili palls of the railroad. A railroad operated on such a segment-by-segment basis would be prone to suboptimization. On the other hand, the history of the railroad management is built around decentralized operations, where geographical districts and sections were set up as responsibility centers in days when communications were elow and uncertain. Thus, elements of suboptimization may still be present in railroads, although some of the largest private communications systems in the nation arc operated by railroad operating companies. 


\section{Abstract Railroad Network}

For purposes of the discussion in this section, a segment of a railroad operating company from location A to location B will be analyzed, as illustrated in Figure 9. The figure shows that in a part of the system beyond $A$, activities are taking place that generate traffic for location $B$ and beyond, and similarly, traffic in the beyond-B region is generated for $A$ and beyond. Industrial pickup and delivery in a terminal area or on branch lines may be included in those regions beyond.

There is a classification yard at location $A$ and at location $B$. The function of the yard is to arrange cars in the proper order and assemble trains with cars with the proper destinations. For example, trains from $B$ arrive at $A$ with cars at many locations beyond $A$. The classification yard at A arranges the cars in groups, or blocks, with common destinations, or going toward points where further grouping may take place. The blocks are assembled into trains that are dispatched for the various destinations beyond A. From the other direction, trains from many locations in the region beyond $A$ arrive at yard $A$. Some cars on the trains are sorted into blocks for other destinations in the beyond-A region, and some for yard $B$, containing cars destined for the region beyond $B$. In some cases, traffic may be dense enough for blocks to arrive at $A$ that are destined for yard $B$ and beyond, in which case, further sorting would not be necessary at yard $A$, and perhaps not at yard $B$. Still heavier traffic would result in trains originating beyond $A$ and terminating at $B$ or beyond $B$, bypassing yard $A$ and perhaps yard $B$ entirely.

The road between $A$ and $B$ carries trains that are made up of locomotives, loaded cars, empty cars, and a caboose.

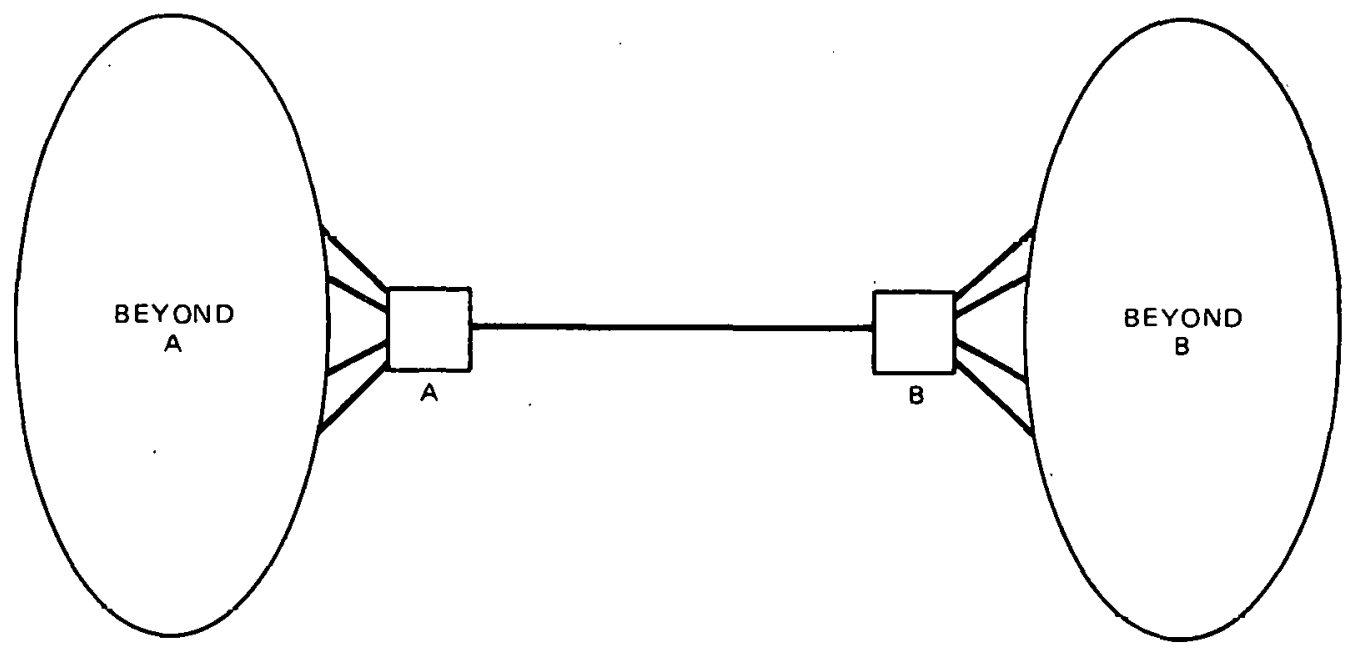

FIGURE 9 ABSTRACT RAILROAD NETWORK 
The components of the abstract network are:

- Mainline railroad

- Way train or branch line car delivery

- Switchyards, including switch engines

- Company costs

\section{Generalized Economic Framework}

Each of the components in the abstract network has costs associated with it. The general categories of cost are capital charges on the investment, maintenance costs, and operating costs. The sum of annual costs in each of these categories, divided by annual tonnage, will give an average cost per ton-mile for the component.

The reader should he aware that potential improvements to the structure of the constants in the models may be made possible by a series of extensive studies under way to develop railroad cost methodology. These studies, covering the following subjects: roadway and track, switchyards, locomotives and cars, signals and communications, and ancilliary services, have been under way for about three years and are expected to continue for several more. The first, a study of roadway and track costs (Ref. 20), was published in January 1976. Although this report was prepared for estimating costs for pricing purposes, it contains estimates of short-run costs that were very useful in constructing the long-run average costs for the main line portion of the cost model.

\section{Long-Run Average Cost Model of Main Line Railroad}

\section{Operational Descriptinn}

A main 1,ine train typically starts its run when it is dispatched from a major classification yard. The train may depart on a timetable schedule or when there are sufficient cars for a district to make up a train. Such a train will be made "p of several blocks, or . groups, of cars, any of which might contain 30 cars. Usually at least one block will include cars destined for points beyond the next major switchyard. Other blocks may contain cars destined for points beyond or intermediate points. The number and type of these intermediate operations is relatively few. In our abstract model. the main line train moves at a scheduled speed from Point A to Pnint $B$ in Figure 9 with no intermediate stops. The main line model provides an estimate of the cost associated with moving the heavy through traffic. 
Main line right-of-way typically has lower grades and curvature and is better maintained than other track on the road. Often multiple tracks with extensive signalization and centralized train control are present. Traffic densities on such lines range upward from 10 million gross tons annually. Trains traveling on these portions of the network average 60 cars in length, and trains of more than 100 cars are not uncommon. Average speeds are $48 \mathrm{~km} / \mathrm{hr}(30 \mathrm{mph})$, although some priority high-speed trains with high priority travel over $128 \mathrm{~km} / \mathrm{hr}(80 \mathrm{mph})$.

\section{Assumptions}

There are several assumptions built into the mainline model in addition to the no-stop provision. They are:

(1) The number of scheduled trains between the two ends of the line is equal in both directions (service is balanced).

(2) The number of engines required for each train is the number required to pull the heaviest train (in either direction) up the ruling grade for the line (In elther direction). This means that there is no imbalance of locomotive equipment on the line and no helper districts (portions of track where engines are added to as for critical grades and then removed).

(3) A11 trains are the same average length and travel at the same average speed for the entire trip.

(4) The number of loaded cars is a function of the net tons to be carried and the average load per car for the segment. Empty cars are some multiple of the number of loaded cars required (e.g., one empty for each load).

(5) Fixed plant-capital costs are constant (not a function of traffic) with the exception of number of tracks (over the same assumed right of way), type of signalization (manual, automat.i.s. hlock system, or CTC), and rail and tie costs.

(6) Rolling stock capital costs (locomotive, car, and caboose) are a function of the time used. This assumption implies that the equipment can be used elsewhere if not on the line under analysis.

(7) Maintenance of way (other than track surfacing and rail and tie replacement) is a constant. 
(8) Locomotive maintenance is related to fuel consumed by a simple constant.

(9) Car maintenance is a linear function of car miles with zero intercept.

(10) Crew costs are a function of time spent. (This assumption may be an optimistic one but can be changed to allow crews to be paid based upon miles, if necessary).

(11) Dispatching costs are a function of train hours. This implies that the dispatcher can be used for other functions (other portions of railroad line) if not required for this line).

(12) All other maintenance (grade crossings, etc.) and taxes are fixed anmual expenses as a function of miles of right-nf-way and capital invested respectively.

These assumptions have been embodied in the mainline model to provide a simple yet flexible tool for the analysis. The calculations and input factors for the model are summarized in the next section.

\section{Model Summary and Basic Input}

For the analysis, capital costs are divided into two parts. The first is fixed plant capital. In this model the costs of land, grading and preparation, structures and culvert, grade crossings, and the communications and control systems are handled as lump-sum investments paid for over a long life at a fixed rate. All costs factors in this calculation are assumed linear functions of miles of right-of-way except for communications and control. The type of control system and cost are calculated based upon the number of trains required to move the traffic. lihe cost of rails, ties, and surtacing are calculated based upon a costper-track-mile and an estimated life (a function of traffic) (Ref. 20). The annual investment is the result of discounting over. this life. Under our assumptions, the number of locomotives is calculated based upon hours required to move the traffic (adjusted for availability). 'l'he cost of the required locomotives is discounted over an average life. Car costs are a linear function of car hours accumulated.

Maintenance of grade crossings, weed control, etc., and ordinary communications are functions of route miles. Locomotive maintenance is a function of the number of gallons of fuel used. Details of the fuel estimation are covered in a later section. Car miles are used to estimate the cost of car maintenance. 
Other costs are fuel costs, crew costs (based upon hours required for a particular availability), dispatch costs (a function of train hours), and taxes. The assumptions require that taxes be calculated as a function of capital (including right-of-way and all improvements: track, crossings, communications).

The input factors required for these calculations and the units are shown in Table 10. Also shown in the table are the nominal. values and the source for these values. The model is set to run on these values or to allow changes to them as desired, depending upon the situation.

These nominal values provide a basis for the calculation of the long-run average cost curve shown in Figure 10. The curve was generated based upon a section of roadway where average trains were 60 cars in length with cars weighing 25 tons and carrying 60 tons per load. Locomotive weights were assumed to be 151 tons. Each load was assumed to generate one empty car in back haul. Several runs of the model showed little or no variation in long-run average cost per net ton-mile as the line length is increased from 200 miles to 1,500 miles.

\section{Branch Line or Local Delivery Operation}

Many railroad patrons are served by road switching or way train - crews who operate along a branch line, setting out and picking up cars at customer sidings; they then proceed to another customer siding further down the line and repeat the operation. In this process, the cars are usually sorted so that the first car to be set out is at the front of the train, allowing the crew to disconnect the car from the rest of the train, push it into the siding, and then recouple the locomotive to the rest of the train; the next car to be delivered is now first, and so on. To model the cost of delivering cars to patrons in this manner, the following assumptions are built into the model:

(1) Al1 empties and loads picked up on the line are returned to the yard serving the line, and all loads and empties set out on the line are switched at the yard. The result of the assumption is that one empty car is carried outbound for each load to be picked up, and one empty is picked up for each load carried outbound.

(2) Crew costs are a function of hours worked, rather than mileage. The runs that have been made with the model show that the time to set out and pick up cars is much greater than the time spent in moving, so the crew would be paid on an hourly rate. 
Table 10

MAIN LINE MODEL VARIABLES

Nominal Units

Definition

or Values

Source for Value

Physical Description of Line

$\begin{array}{ll}\text { Net elevation change dir. } 1 & 6.700 \mathrm{ft} / \mathrm{mi} \\ \text { Descent Class C direction } 1 & 0.000 \mathrm{ft} / \mathrm{mi} \\ \text { Descent Class C direction } 2 & 0.790 \mathrm{ft} / \mathrm{mi} \\ \text { Ruling grade direction } 1 & 1.000 \% \\ \text { Ruling grade direction } 2 & 0.600 \% \\ \text { Mi of } 1^{\circ} \text { curves } & 0.033 \mathrm{mi} / \mathrm{tk}-\mathrm{mi} \\ \text { Mi of } 2^{\circ} \text { curves } & 0.000 \mathrm{mi} / \mathrm{tk}-\mathrm{mi} \\ \text { Mi of } 3^{\circ} \text { curves } & 0.033 \mathrm{mi} / \mathrm{tk}-\mathrm{mi} \\ \mathrm{Mi} \text { of } 4^{\circ} \text { curves } & 0.000 \mathrm{mi} / \mathrm{tk}-\mathrm{mi} \\ \mathrm{M} 1 \text { of } 5^{\circ} \text { curves } & 0.000 \mathrm{mi} / \mathrm{tk}-\mathrm{mi} \\ \mathrm{Mi} \text { of } 6^{\circ} \text { curves } & 0.033 \mathrm{mi} / \mathrm{tk}-\mathrm{mi} \\ \mathrm{Mi} \text { of } 7^{\circ} \text { curves } & 0.000 \mathrm{mi} / \mathrm{tk}-\mathrm{mi} \\ \mathrm{Mi} \text { of } 8^{\circ} \text { curveo } & 0.001 \mathrm{mi} / \mathrm{tk}-\mathrm{mi} \\ \mathrm{Mi} \text { of } 9^{\circ} \text { curves } & 0.000 \mathrm{mi} / \mathrm{tk}-\mathrm{mi} \\ \mathrm{Mi} \text { of } 10^{\circ} \text { curves } & 0.001 \mathrm{mi} / \mathrm{tk}-\mathrm{mi} \\ \mathrm{Mi} \text { of } 11^{\circ} \text { curves } & 0.000 \mathrm{mi} / \mathrm{tk}-\mathrm{mi} \\ \mathrm{Mi} \text { of } 12^{\circ} \text { curves } & 0.001 \mathrm{mi} / \mathrm{tk}-\mathrm{mi} \\ \mathrm{Mi} \text { of } 13^{\circ} \text { curves } & 0.000 \mathrm{mi} / \mathrm{tk}-\mathrm{mi} \\ \mathrm{Mi} \text { of } 14^{\circ} \text { curves } & 0.000 \mathrm{mi} / \mathrm{tk}-\mathrm{mi}\end{array}$

Capital-related factors

Land cost

$90,000.00 \$ \$ / \mathrm{mi}$

Grading and preparation

$250,000.000 \$ / \mathrm{mi}$

Structures and culverts

$80,000.000 \$ / \mathrm{mi}$

Roadway less rails and

$69,800.000 \$ / \mathrm{mi}$

lies

Communications and

$25,000.000 \$ / t k-m i$

control, manual

Communications and

$18,000.000 \$ / \mathrm{tk}-\mathrm{mi}$

Reference 2

control, ABS

Communications and

contiol, C'l'C

$30,000.000 \$ / t k-m i$

0.500 ratio

Calculated from a track chart for the Southern Pacific main line from Wellton to Picacho, Arizona

Incremental communications sost/additional

track

Grade crossing, unprotected

$3,950.000 \$ / \mathrm{mi}$

0.79 crossings $/ \mathrm{mi}$

(Ref. 20) $\$ 5,000 /$

crossing (Ref. 21)

Land at $\$ 10,000 /$ acre;

50 feet wide $\$ 30,000$

for acquisition,

clearing, etc.

SK $\perp$ estimate

50 foot bridge, 200

foot culverts/mi; cost

from Ref. 21

$\$ 35 / \mathrm{ft}$, estimated

Iroü Ref. 21 \& 22

SRI estimate 
Tab1e 10 (Continued)

MAIN LINE MODEL VARIABLES

Definition
Grade crossing, pro-
tected
Locomotive costs
Locomotive life
Average locomotive hp
Car capital costs

Maintenance

Weed control, etc.

Communications and control maintenance, manual. Communications and control maintenance, ABS Communications and control maintenance, CTC Grade crossing maintenance, unprotected

Grade crossing maintenance, protected

Tie replacement cost

Rail replacement cost

Rail weight

Surfacing costs

Locomotive maintenance

Car maintenance

$\begin{gathered}\text { Nominal Unj.ts } \\ \text { or Values }\end{gathered}$
$7,700.000 \$ / \mathrm{mi}$
$250,000.000 \$ /$ unit
$20.000 \mathrm{years}$
$2000.000 \mathrm{hp} / 1 \mathrm{oc}$
$0.500 \mathrm{\$} /$ car-hr

Source for Value

0.22 crossing/mi ref. 1 ; $\$ 35,000 /$ crossing (Ref. 22)

(Ref. 12)

SRI estimate

SRI estimate

(Ref. 21)

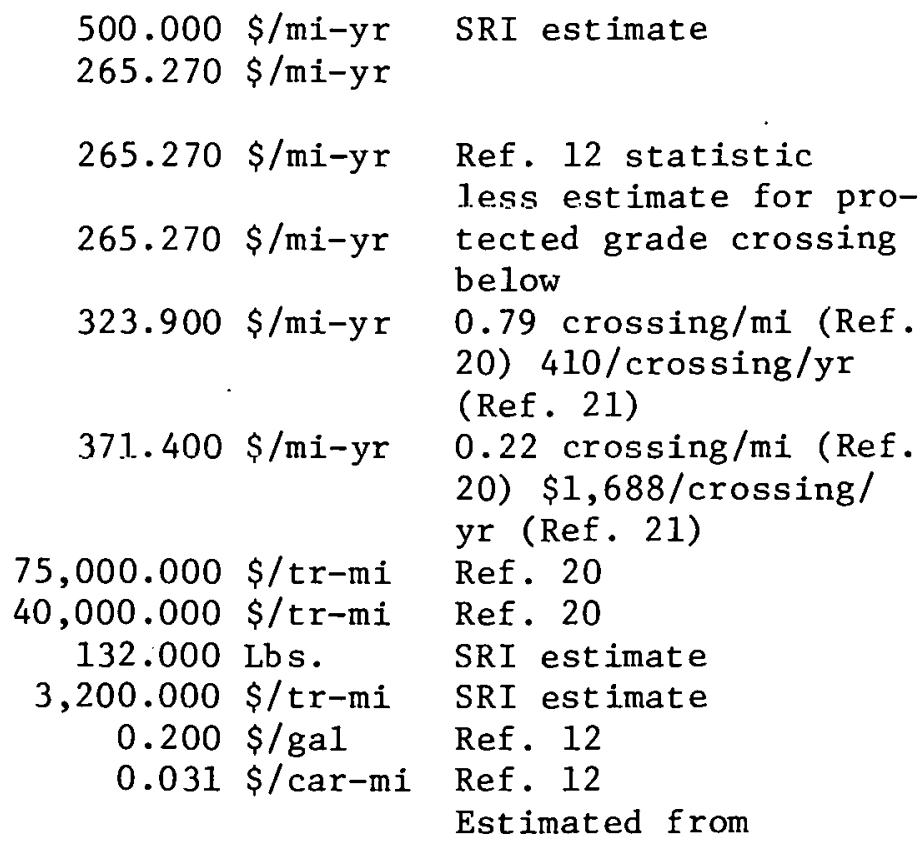

Operating and Miscellaneous

Fue1 cost
Crew cost
Crew utilization
Dispatch cost-manual

Fue1 cost.

$0.350 \$ / g a 1$ $28.040 \cdot \$ / \mathrm{hr}$

Ref. 23

3-man crew, wages, benefits and tax from Ref. 23

$0.880 \mathrm{hrs}-\mathrm{avl} / \mathrm{SRI}$ estimate $\mathrm{hr}$

1.150 \$/train- Ref. 21 mi 
Table 10 (Continued)

MATN LINE MODEL VARIABLES

\begin{tabular}{|c|c|c|}
\hline $\begin{array}{l}\text { Definition } \\
\text { Physical Description of Line }\end{array}$ & $\begin{array}{l}\text { Nominal Units } \\
\text { or Values }\end{array}$ & Source for Value \\
\hline Dispatch Cost-ABS & $\begin{array}{l}0.000 \$ / \text { train- } \\
\text { mi }\end{array}$ & SRI estimate wage \\
\hline Dispatch cost-CTC & $\begin{array}{l}0.020 \$ / \text { train- } \\
\mathrm{mi}\end{array}$ & $\begin{array}{l}1 \mathrm{man} \text { e } \$ 40,000 / \mathrm{yr} \\
\text { controlling } 100 \mathrm{mi} \\
\text { track w/ } 60 \text { trains/day }\end{array}$ \\
\hline Empties to loads & 1.000 ratio & $\begin{array}{l}\text { Balanced empties to } \\
\text { loaded cars }\end{array}$ \\
\hline Percent net tons-direction & 0.500 ratio & Balanced traffic \\
\hline Locomotive availability & $7,889.000 \mathrm{hrs} / \mathrm{yr}$ & $90 \%$ of total year \\
\hline Speed & $30.000 \mathrm{m1} / \mathrm{hr}$ & \\
\hline Taxes & $\begin{array}{l}0.020 \$ / \$ \mathrm{capt} / \\
\text { yr }\end{array}$ & SRI estimate \\
\hline
\end{tabular}




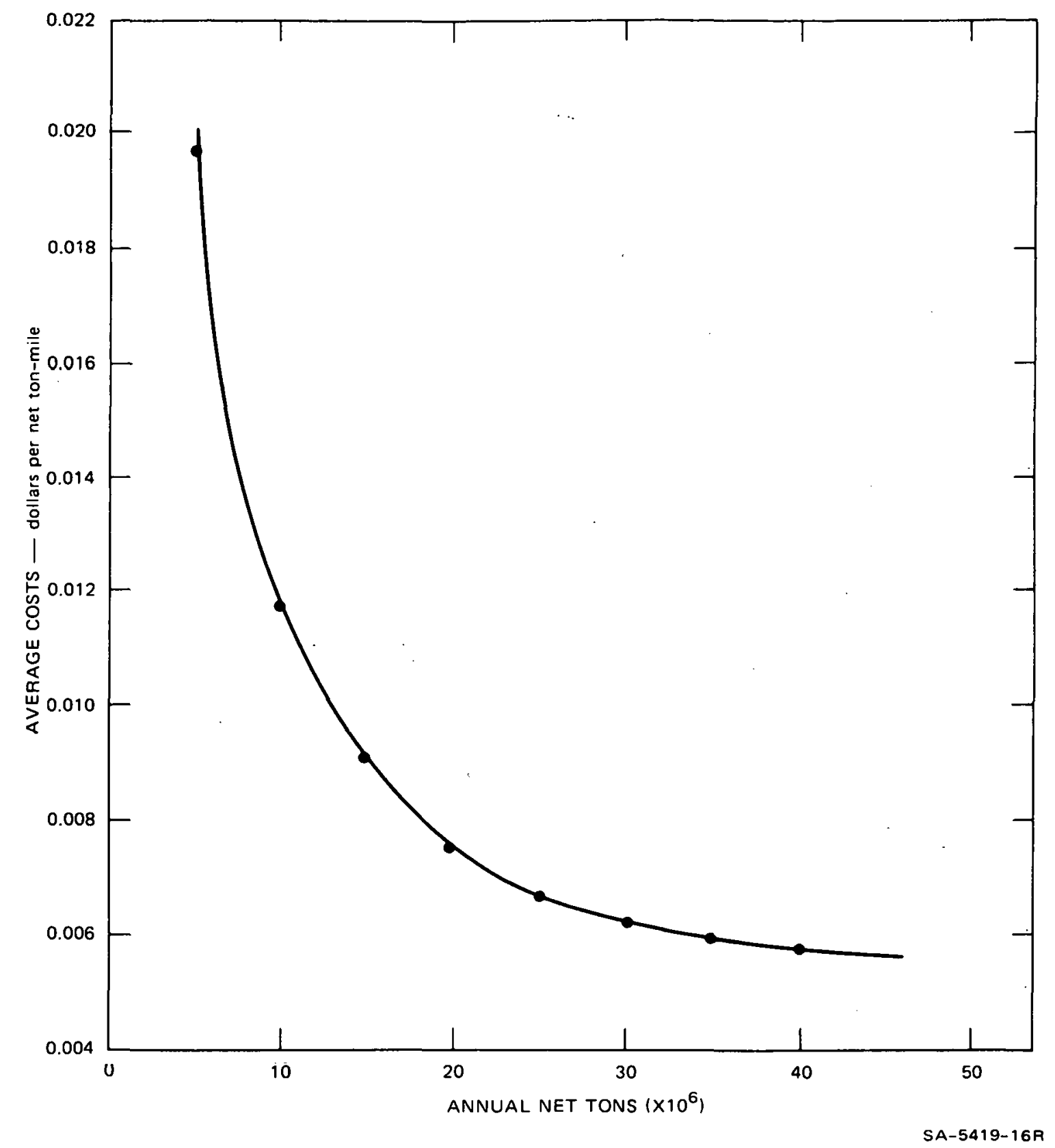

FIGURE 10 MAINLINE COMPONENT LONG RUN AVERAGE COST MODEL 
(3) Locomotive time can be used elsewhere if not on the line under analysis. This assumption allows the estimation of locomotive capital cost from the hours of locomotive time used on the line.

(4) Road maintenance is not a function of annual tonnage. This assumption was made because of low-density lines being considered; further, low speeds, and hence minimal maintenance, are expected.

(5) Locomotive maintenance can be related to fuel consumed by a simple factor.

(6) Freight car maintenance is a Linear function of car m1les, and has zero intercept. The interccpt would have lo be allocated among all of the activities performed by the car, so we have avoided the allocation.

(7) Car time can be used elsewhere if not on the line under analysis; therefore, capttal charges for cars on the line are proportional to time spent by the car on the line.

Factors used in the model are detailed in Table 11. The mode1 considers the cost of capital invested in the construction of the roadbed and the acquisition, clearing, and preparation of the land; that is, the roadbed cost multiplied by the discount rate to determine the annual equivalent of the land and grading, which are assumed to have very long lives. Also considered are the capital charges for rail and ties, including periodic replacement as they deteriorate because of $\tau 1 \mathrm{me}$, for this model, rather than because of mileage. Again, the installation cost and lite are considered to construct the annudl cusl Lu recover the initial investment over the life of the assets. Costs of grade crossings are similarly treated, with a fixed annual crossing maintenance cost considered with other fixed annual mainlenance costs for weed control, juint bar tightening, and so on. No signaling is assumed, so no signal cost or maintenance is included. Taxes are assumed to be a fixed percent of the investment in land, improvements, and track and tiec.

Since it is expected that relatively luw speeds will be used on the branch line, figures for grades and curves per mile will be higher Lhan fur main lines.

Table 11 also shows other user-supplied factors and their nominal values. The table also shows the source of the value of the estimate. The factors are derived from January $19 / 4$ prices or estimates based on prices prevailing at that time. 
Table 11

FACTORS USED IN COST MODEL FOR BRANCHLINE

\begin{tabular}{|c|c|c|c|}
\hline Factor & $\begin{array}{l}\text { Nominal } \\
\text { Value }\end{array}$ & Units & Remarks or Source \\
\hline Land, clearing, etc. & $\$ 90,000$ & $\$ / \mathrm{mi}$ & $\begin{array}{l}\text { Land at } \$ 10,000 / \text { acre; } 50 \\
\text { foot wide strip } \$ 30,000 \\
\text { for acquisition, clear- } \\
\text { ing, etc. }\end{array}$ \\
\hline Grade crossings & 889 & $\$ / \mathrm{mi}$ & $\begin{array}{l}0.889 \text { crossings/mi (Ref. } \\
22) ; @ \$ 1,000 / \text { crossing }\end{array}$ \\
\hline Grading + preparation & $\$ 100,000$ & $\$ / m i$ & SRI estimate \\
\hline Structures + culvert & $\$ 80,000$ & & $\begin{array}{l}50 \text { foot bridge, } 200 \text { foot } \\
\text { culverts/mi; cost from } \\
\text { Ref. } 21\end{array}$ \\
\hline Roadway less rail and ties & $\$ 69,800$ & $\$ / \mathrm{mi}$ & $\begin{array}{l}\$ 35 / \mathrm{ft} . \text { estimated from } \\
\text { Ref. } 20 \text { and } 21\end{array}$ \\
\hline Grade crossing maintenance & 268 & $\begin{array}{l}\$ / \mathrm{mi} / \\
\mathrm{yr}\end{array}$ & Unit cost from Ref. 21 \\
\hline Weed control, etc. & 500 & $\begin{array}{l}\$ / \mathrm{mi} / \\
\mathrm{yr}\end{array}$ & SRI estimate \\
\hline Taxes & $\$ 0.015$ & $\$ / y x$ & SRI estimate \\
\hline Tie replacement & $\$ 75,000$ & $\$ / \mathrm{mi}$ & Ref. 20 \\
\hline Tie life & 40 & $\$ / y r$ & Ref. 20 \\
\hline Rail replacement & $\$ 40,000$ & $\$ / \mathrm{mi}$ & Ref. 20 \\
\hline Rail life & 250 & yr & Ref. 20 \\
\hline Branch line speed & 10 & $\mathrm{mi} / \mathrm{hr}$ & SRI estimate \\
\hline Time for setout/pickup & 0.300 & $\mathrm{hr} / \mathrm{car}$ & SRI estimate \\
\hline Locomotive available & 7,889 & $\mathrm{hr} / \mathrm{yr}$ & $90 \%$ of total yr \\
\hline Locomotive cost & $\$ 250,000$ & \$/unit & Ref. 12 \\
\hline Locomotive life & 20 & yrs & SRI estimate \\
\hline Car time charge & 0.500 & $\begin{array}{l}\$ / \text { car- } \\
\mathrm{hr}\end{array}$ & Ref. 21 \\
\hline Car detention by customer & 72 & $\mathrm{hr} / \mathrm{car}$ & SRI estimate \\
\hline Car maintenance cost & 0.031 & $\begin{array}{l}\text { \$/car- } \\
\text { mi }\end{array}$ & $\begin{array}{l}\text { Estimates by SRI from } \\
\text { Ref. } 1.2\end{array}$ \\
\hline Crew cost & 28.040 & $\$ / \mathrm{hr}$ & $\begin{array}{l}\text { 3-man crew, wages, H\&W } \\
\text { benefits, payroll tax } \\
\text { from Ref. } 23\end{array}$ \\
\hline
\end{tabular}


Table 11 (continued)

FACTORS USED IN COST MODET, FOR BRANCHLINE

\begin{tabular}{|c|c|c|c|}
\hline Factor & $\begin{array}{l}\text { Nominal } \\
\text { Value }\end{array}$ & Units & Remarks or Source \\
\hline Dispatch cost & 1.150 & $\begin{array}{l}\text { \$/train- } \\
\mathrm{mi}\end{array}$ & Ref. 21 \\
\hline Fuel cost & 0.350 & $\$ / g a l$ & Ref. 23 \\
\hline Locomotive maintenance & 0.203 & $\begin{array}{l}\text { \$/gal } \\
\text { used }\end{array}$ & $\begin{array}{l}\text { Estimated from Ref. } \\
12\end{array}$ \\
\hline Descent outbound, Class C & 10 & $\mathrm{ft} / \mathrm{mi}$ & \\
\hline Elevation change outbound & 10 & $\mathrm{ft} / \mathrm{mi}$ & Approximation of \\
\hline $\begin{array}{l}\text { Descent inbound, Class C } \\
\text { Elevar1on change inbound }\end{array}$ & $\begin{array}{r}10 \\
-10\end{array}$ & $\begin{array}{l}\mathrm{ft} / \mathrm{mi} \\
\mathrm{ft} / \mathrm{mi}\end{array}$ & Wheeliiing Téluliual \\
\hline Curvature per mile & 20 & degrees & $\begin{array}{l}\text { Branch, Penn-Lentral } \\
\text { Railroad }\end{array}$ \\
\hline $\begin{array}{l}\text { Crew utilization } \\
\text { Loads outbound to total loads }\end{array}$ & $\begin{array}{l}0.875 \\
0.500\end{array}$ & $\begin{array}{l}\mathrm{hr} / \mathrm{hr} \\
\text { ratio }\end{array}$ & $\begin{array}{l}\text { SRI estimate } \\
\text { SRI estimate }\end{array}$ \\
\hline
\end{tabular}


Car and locomotive weights and loads were determined from ICC statistics for 1973. The interest rate approximates the discount rate after taxes for a profitable railroad.

Another feature of the model is the automatic selection of train frequency, based on a specified minimum number of cars per train and the annual tonnage to be carried. The train length-frequency combinations have been tested to determine a least-cost operation. The combinations are listed below.

\section{Trains/ \\ Year}

12

26

52

104

156

208

260

312

365
Min Cars/
Train

\section{2}

2

2

2

4

8

13

15

17
Annual

Cars

24

52

104

208

624

1,664

3,380

4,680

6,205

Results produced by the branch line model are shown by Figures 11 and 12. Figure 11 shows the long run average cost envelope for branch line operations and the annual train frequency as a function of annual net tons originated and terminated on the line, for an assumed 20 mile long line. Figure 12 shows the effect of changing the length of the line from 10 to 20 miles, as a function of annual tonnage.

\section{Switchyard Component of Railroad Cost}

The operations of a switchyard are much more complex than those of the main line train or the way train, involving such operations as inspecting cars, bleeding brakes, switching (which may involve several movements of the car or the switch engine), making up trains, lacing the air (connecting air hoses between cars), and brake checking. The complexity and diversity of operations limits the ability to produce a functional description that is useful for constructing a cost model of the yard. Because of this limitation, relationships between cost of operations, output, and size of the yard were derived from a survey of switchyards that was conducted in early 1976 by SRI. 


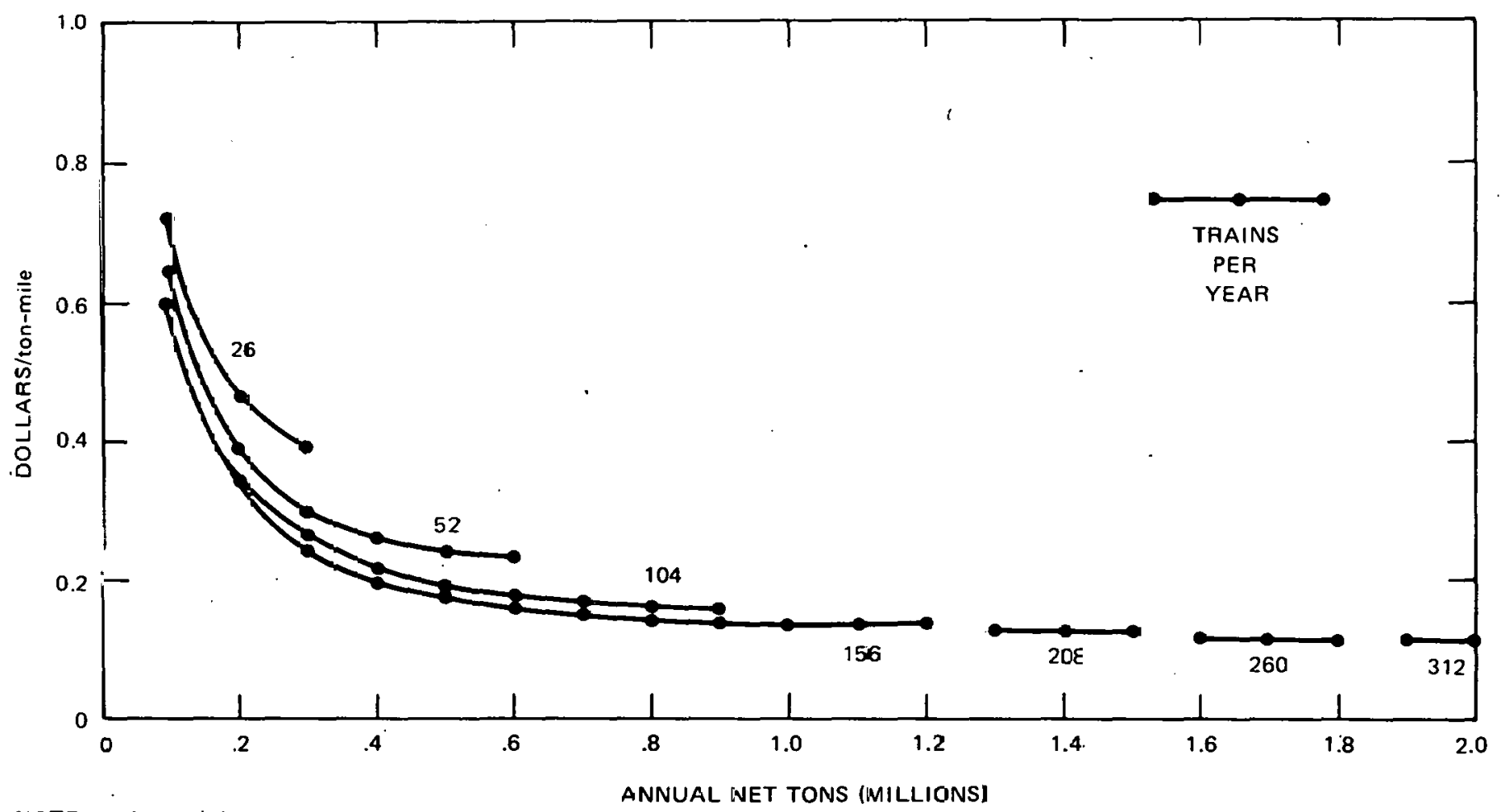

NO'E: $20 \mathrm{mi} \mathrm{e} / 10 \mathrm{mph}$ speed.

FIGURE I1 AVERIAGE COST OF WAY TRAIN OPERATIDN ON BRAPCH LINES 


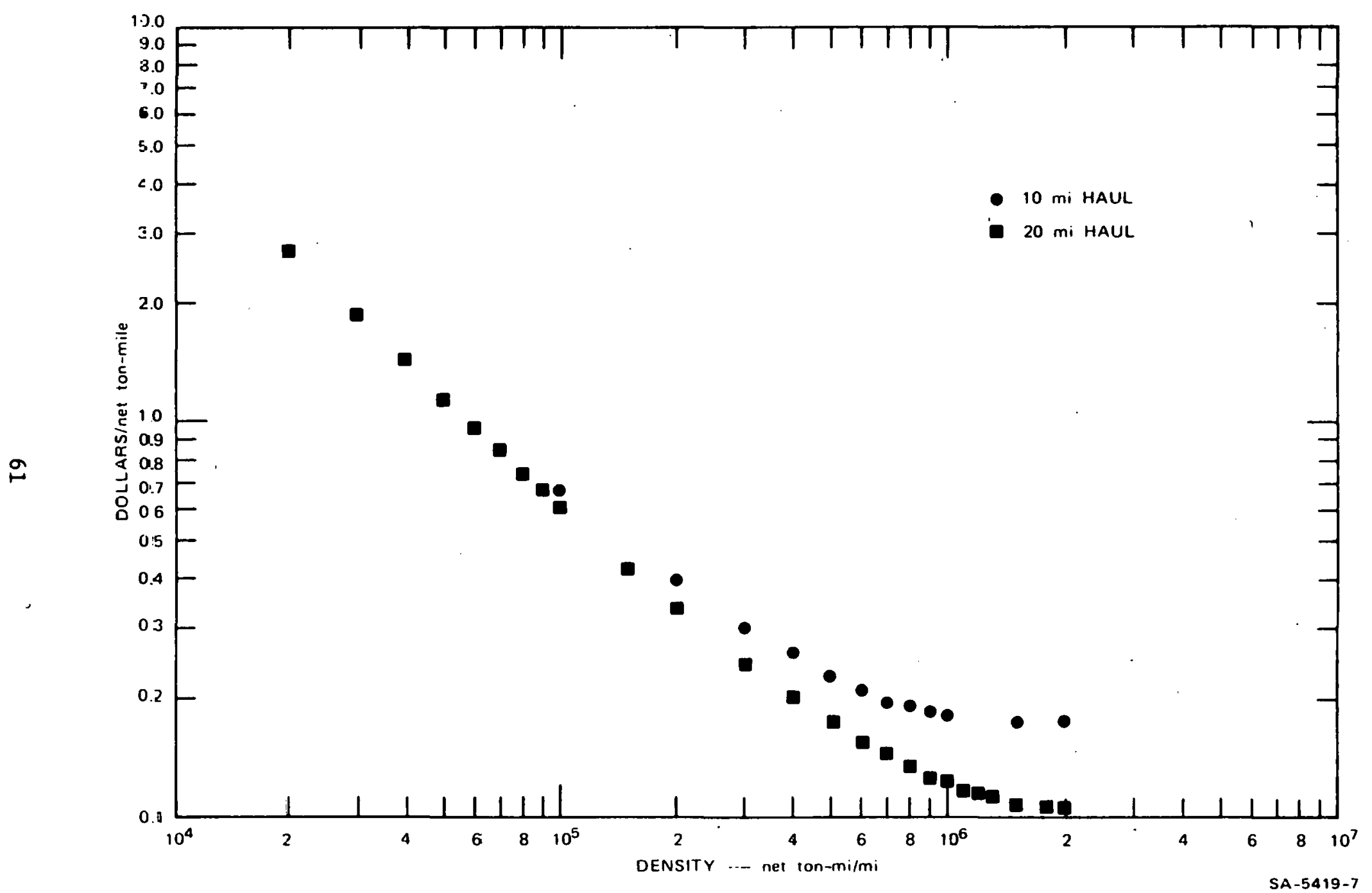

FIGURE 12 EFFECT OF LENGTH OF HAUL ON AVERAGE COST - BRANCH LINE 
The long-run cost of switchyard operations comprises three factors: nonmaintenance operating costs, maintenance operating costs, and capital charges. From the responses of 141 flatyards and 47 hump yards an SRI's questionnaire, the relationships between these costs on the one hand and yard output and capacity on the other were estimated and used to construct a computerized model of switchyard operations. The questionnaire data base was developed as a result of another project documented in Reference 10. The model was then used to derive long-run total and average costs. Descriptions of the cost components, the estimation of their relationship to yard capacity and output, the construction of the model, and some preliminary findings follow.

Non-maintenance operating costs refers only to maintenance of way and structures, which were separated from other operating costs because the questionnaire contained no data useful in estimating them. The measure of output on which non-maintenance operating costs were postulated to depend is the number of industrial and nonindustrial cars dispatched per day. The measure of yard size on which investment costs and economics of fixed-plant scale were postulated to depend is the total storage capacity (cars) of the yard.

In the sample of 141 flat yards and 47 hump yards from which this equation was estimated, data on storage capacity, Industrial cars dispatched, and nonindustrial cars dispatched were available explicitly. But the data on nonmaintenance operating costs were not and therefore had to be constructed from those components of nonmaintenance operating costs for which data were available. Total cost was postulated to have five components: the cost of supervisors, maintenance of equipment (MOE) employees, clerks, and switch engine activity, as well as a charge per car-hour of detention time. Since the data on cars dispatched were per day of operations, the cost of the components per day had to be calculated from the data available: the number of supervisors, MOE employees, clerks employed, and switch engine tricks per day. (Detention charges were simply the product of the number of cara dispatched per day, the average car detention time, and the charge per car.)

For supervisors, MOE employees, and clerks, the average annual salary (including overtime and benefits: $\$ 17,895, \$ 13,820$, and $\$ 13,620$ respectively) was divided by days worked per year $(210,230$, and 220 ) to get cost per day of operation $(\$ 85.22, \$ 60.09$, and $\$ 61.91)$. + The cost of a switch engine trick (includes depreclatiun and maintenance) was estimated at $\$ 482.32 .^{\ddagger}$ The sum of the cost per day of these

In this discussion, industrial cars are thost cars picked up or set out at eustomer siding by yard switch crewa. Noninductrial cars are those that are received from road trains, switched, and dispatched on outbound road trains.

† 1974 annual salaries for supervisors and MOE men; 1974 annual salary for clerks, estimated by SRI from questionnaire results (Ref. 23). $\$$

Estimated by SRI from discussions with officials of the Southern Pacific Railroad. 
five components thus yields a short-run operating cost per day

(excluding maintenance of way and structures, discussed below).

To determine the relationship between this cost (C), total storage capacity, and industrial and nonindustrial cars dispatched, a nonlinear functional form was estimated with the following results:

$$
C=1.9589 \mathrm{~K}+4.1522 \mathrm{Q}_{1}^{1.1692} \mathrm{~K}^{-.00082188}+504.29 \mathrm{Q}_{2} .34979 \mathrm{~K} \cdot 20681
$$

with $\mathrm{R}^{2}=.99$

where

$$
\begin{aligned}
& \mathrm{K}=\text { total storage capacity } \\
& \mathrm{Q}_{1}=\text { nonindustrial cars dispatched/day } \\
& \mathrm{Q}_{2}=\text { industrial cars dispatched/day }
\end{aligned}
$$

This form was chosen because each term corresponds to a different activity: the first, to the fixed component of operating costs, postulated to be proportional to the size of the yard (total storage capacity); the second, to the variable component of operating costs attributable to dispatching nonindustrial cars, with average and marginal costs postulated to vary with the level of activity and the size of the yard; and the third, to the variable component of operating costs attributable to dispatching industrial cars, with average and marginal costs varying analogously.

The following equation was used to calculate the cost of maintaining way and structures (Ref. 24, p. VII-10B).

$$
\text { MOC }=17750 .+.22045 Q Y R
$$

where $\mathrm{MOC}=$ cost per year

$$
\text { QYR = cars dispatched per year }
$$

Since switch engine depreciation is included in the cost per switch-engine-hour component of nonmaintenance operating costs, investment from which capital charges arise consists only of that in land and track. Because data on each yard's average and track mileage were not available from the questionnaire, another sample of ten yards was used to determine the relationship between land or track on the one hand and the storage capacity of the yard on the other.* Data on

\footnotetext{
*Data on the acreage and track mileage of ten yards with varying storage capacities (Ref. 25, p. 55).
} 
storage capacity were available from the questionnaire, so that the land and track necessary to support a yard of a given storage capacity could be extrapolated from that needed by the ten yards in the sample. The following equations were used:

$$
\begin{aligned}
& \mathrm{L}=0.014024 \mathrm{~K}^{1.1930} \mathrm{R}^{2}=0.50 \\
& \mathrm{~T}=0.032426 \mathrm{~K}^{0.91901} \mathrm{R}^{2}=0.61
\end{aligned}
$$

where $\mathrm{L}=$ land (acres)

$$
\begin{aligned}
& \mathrm{T}=\text { track (miles) } \\
& \mathrm{K}=\text { storage capacity (cars) }
\end{aligned}
$$

The investment cost of the land and track necessary to construr.t a yard with a given storage capacity is simply the product of the requirements from the equations above and the unit price of each component.

To estimate fuel used as a function of the output of the yard, the following relationship was estimated from the sample:

$$
\mathrm{SET}=7.6535+0.0075665 \mathrm{Q}_{1}+0.062982 \mathrm{Q}_{2} \mathrm{R}^{2}=0.48
$$

where SET = switch engine tricks

$$
\begin{aligned}
& Q_{1}=\text { nonindustrial cars dispatched/day } \\
& Q_{2}=\text { Industrial càrs dispatched/day }
\end{aligned}
$$

The model assumes each trick takes 8 hours. The gallons of fuel consumed per switch-engine-hour (an input variable) multiplied by cwitch-enginehours yields the fuel used to dispatrh a given number of cars.

The current version of the model has fourteen input variables with the following default values:

$\begin{array}{lr}\text { Minimum nonindustrial tons/per year (thousands) } & 1,000 \\ \text { Maximum nonindustrial tons/per year (thousands) } & 25,000 \\ \text { Incremental nonindustrial tons/per year } & 1,000 \\ \text { Interest rate } & 0.10\end{array}$

Days of operation/per year 365

Loaded nonindustrial cars/per total $\quad 0.550$

Tons/per nonindustrial cars $\quad 30$ 

Dollars/per acre
16,832
Dollars/per track-mile
396,000
Gallons/per switch-engine-hour
7.4
Average yard load factor
0.750
Number of parameter modification sets
0.1
Loaded industrial cars/per year
To be determined
Tons/per industrial car
30.0

The default values in the model are $\$ 16.832 /$ per acre and $\$ 396,000 /$ per track-mile (or $\$ 75 /$ per track-foot). Capital charges per year are then just this initial investment multiplied by the interest rate (Ref. 26, p. 3).

The annual capital charge is the product of investment and the interest rate because of the long life of the investments (infinite for land, 250 years for track). The formula is:

$$
C=I \frac{\cdot r(1+r)^{L}}{(1+r)^{L}-1}
$$

where $\quad \mathrm{C}=$ annual capital charge

$I=$ investment

$r=$ interest rate

$\mathrm{L}=$ life of investment

As $L$ approaches $\infty, C$ approaches $I \cdot \dot{r}$. For $L=250$, the difference between

$$
\frac{r(1+r)^{L}}{(1+r)^{L}-1}
$$
and $r$ is insignificant for the relevant ranges

of $r$.

The number of nonindustrial cars/per year is calculated from tons/ per year, tons/per loaded car, and loaded cars/per total cars. The sum of nonindustrial and industrial cars/per day (exogenous) is divided by the average yard load factor to calculate the maximum number of cars a yard will ever have to dispatch in a day. An equation relating this maximum number of cars to the total storage capacity needed to handle them was estimated from the sample with the following results: 


$$
\begin{aligned}
& \mathrm{K}=3207.5+1421.1 \mathrm{Q}_{\max } .17823 \\
& \text { where } \mathrm{K}^{\prime}=\text { storage capacity } \\
& \mathrm{Q}_{\max }=\text { maximum number of cars dispatched in a day. }
\end{aligned}
$$

Total and average operating costs, capital charges, and fuel usage are then calculated by the methods described above.

In the operation of the model, five long-run average cost curves were generated by postulating five levels of industrial cars/per year and letting nonindustrial tons/per year vary between 1 and 25 million for each level of industrial cars/per year (Figure 13). With no industrial cars in the syetcm, average cost per car is almost constant at slightly more than $\$ 20 /$ per car. The average costs of yards which dispatch some industrial cars exhibit more conventional behavior, starting at a high ranging from $\$ 49$ to $\$ 58 /$ per car and leveling off to between $\$ 23$ and $\$ 24 /$ per car.

\section{Company Costs}

Company costs are a group of costs more related to company operations and shipments than are the operation costs of the main line, the branchline, or the switchyard. Included in this group of costs are those of administration, traffic, loss and damage, and fixed-cost portions of supervision and equipment maintenance. An explicit model has not been prepared for these costs at this time, because it is not clear that these costs wi 1.1 be relcvant Lu decisions or alternatives to be analyzed later in the project. To gain an indication of the magnitude of these costs, Table 1.2 shows the expenditures for each of these items by Class I railroads in 1973 and 1974, and the total of these costs avcraged uver the ton-miles of freight produced in the lwo ycars.

\section{A Company-by-Company Approach to Railroad Costs}

Although the actions of railroad management are constrained by the existing facilitles, regulations and institutional factors that limit flexibility to change, and uncertainty about future traffic levels, ind1vidual. company managements can still make certain tradeoffs to make the best use of their assets, route structure, and traffic patterns. Thus, the analysis of a firm or the analysis nf a "typical." firm $1 \mathrm{~s}$ descriptive of the behaviur of costs of railroad operation as far as individual flrms are concerned. In this section, the costs of the aggregate firm will be analyzed; then the causes of variation from firm to firm will be examined. 


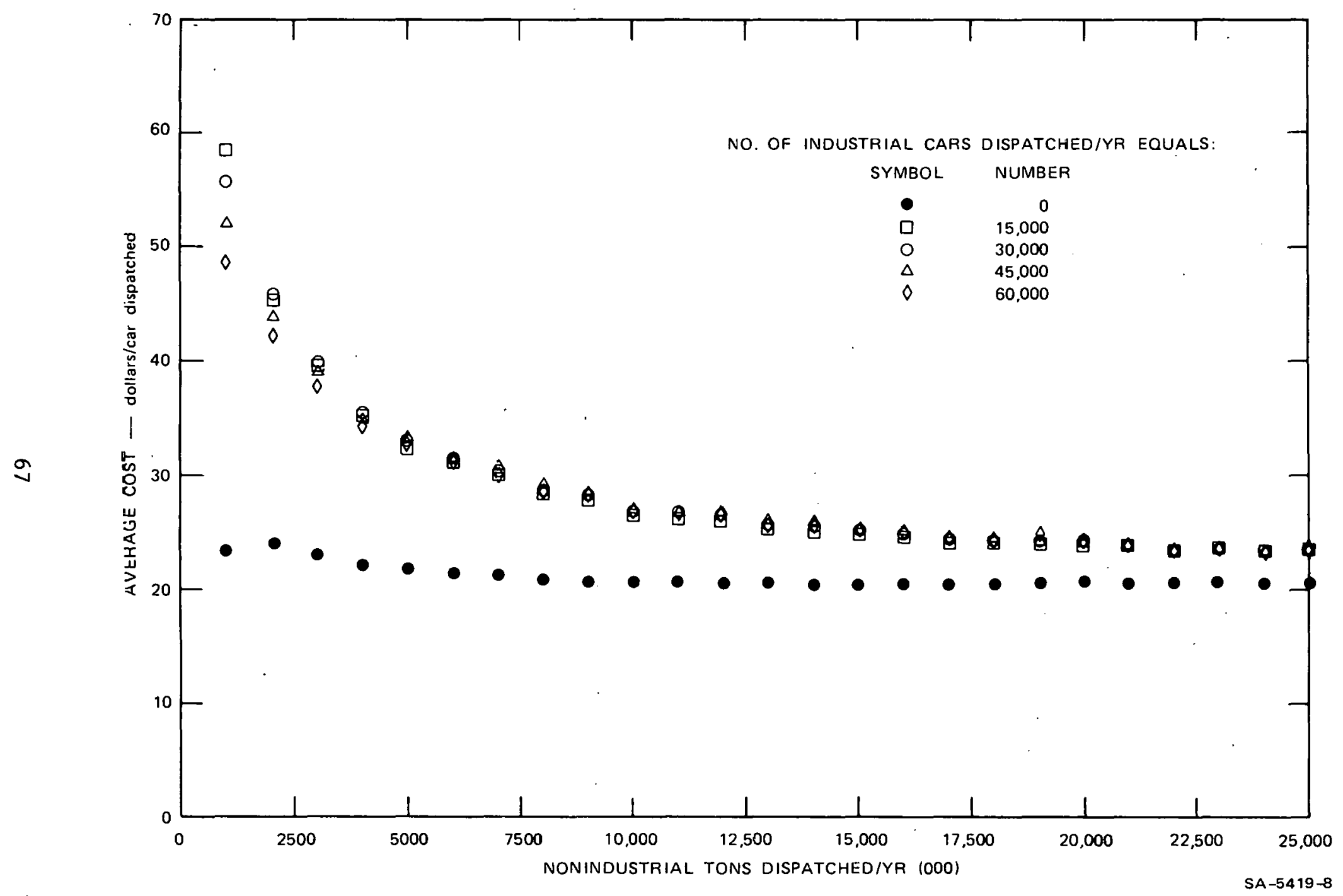

FIGURE 13 LONG-RUN AVERAGE COST OF SWITCHYARD OPERATIONS 
Table 12

SELECTED COST COMPONENTS FOR FREIGHT SHIPMENTS -

C.T.ASS T TITNEHAUIL RAILROADS

\begin{tabular}{|c|c|c|c|c|}
\hline \multirow[t]{2}{*}{ Expense Item } & \multicolumn{2}{|c|}{$\begin{array}{l}\text { Expenditures } \\
\text { (millions) }\end{array}$} & \multicolumn{2}{|c|}{$\begin{array}{l}\text { Average Expenditure } \\
\text { (c per ton-mile) }\end{array}$} \\
\hline & 1973 & 1974 & 1973 & 1974 \\
\hline General & $\$ 750$ & $\$ 807$ & $0.09 \mathrm{c}$ & $0.10 c$ \\
\hline Traffic & 301 & 315 & 0.04 & 0.04 \\
\hline $\begin{array}{l}\text { Freight loss and } \\
\text { damage }\end{array}$ & 227 & 302 & 0.03 & 0.04 \\
\hline \multicolumn{5}{|l|}{ Superintendence } \\
\hline $\begin{array}{l}\text { Maintenance of } \\
\text { way and structures }\end{array}$ & 188 & 207 & 0.02 & 0.02 \\
\hline $\begin{array}{l}\text { Maintenance of } \\
\text { equipment }\end{array}$ & 104 & 113 & 0.01 & 0.01 \\
\hline Transportation & 241 & 264 & 0.03 & 0.03 \\
\hline Totan. & 1,811 & $\$ 2,003$ & $0.21 c$ & $0.24 c$ \\
\hline
\end{tabular}

Note: Totals may not add because of rounding.

Source: Ref. 11, 12 . 


\section{A Long-Run Average Cost Model of a Railroad Company}

A literature review has yielded a long-run average cost model for describing the aggregate activities of railroads. This model, (Ref. 27) can be used to calculate the short-run total costs for various levels of output (that is, the variation in costs with output when investment in way and structures is assumed fixed) and the long-run costs.

The basic functional form of this model is derived from an econometric analysis of pooled time-series/cross-section data from 1969-1971. The short-run total cost relationship derived from this model takes the form

(1) $\mathrm{SRTC}=18.75 \mathrm{~T}+\left(1.330 \mathrm{Q}_{1}^{1.007}+3.074 \mathrm{Q}_{2}^{1.007}\right)^{1.252 \mathrm{~T}^{-.252}}$

where SRTC = short-run total costs (in thousands of dollars annually)

$$
\begin{aligned}
& \mathrm{T}=\text { track miles } \\
& \mathrm{Q}_{1}=\text { millions of gross ton-miles of freight output } \\
& \mathrm{Q}_{2}=\text { millions of gross ton-miles of passenger output }
\end{aligned}
$$

This can be used to derive the long-run total cost function by differentiating short-run total costs with respect to the fixed factor, $\mathrm{T}$, and solving for the optimum $\mathrm{T}$ and substituting it in the short-run total cost function. Using this technique, the long-run total costs (LRTC) can be calculated to be:

$$
\text { LRTC }=3.963 Q_{1}^{1.007}+9.161 Q_{2}^{1.007}
$$

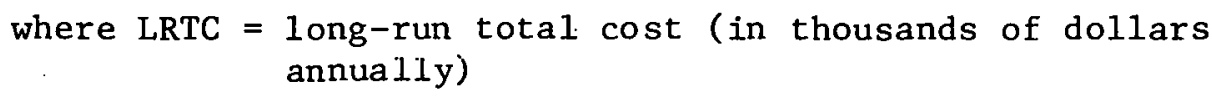

Note that the long=rul cust function implies that paccenger tonmiles $\left(Q_{2}\right)$ generate long-run costs per marginal ton-mile 2.3 times that generated by freight ton-miles. Note also that the coefficient of output is very close to one, implying that there are essentially constant returns-to-scale. This suggests that there is nothing inherently inferior to either a large- or small-scale firm in terms of being able to produce ton-miles efficiently once the business is attracted to the firm. The study was based on roads with 500 miles ${ }^{\circ}$ inure of track, oo that these results may not hold for smaller roads. Griliches (Ref. 28) 
suggests that roads of a smaller scale tend to have a larger fraction of fixed costs, generating some initial economies of increased scale, but these are not relevant at larger scale.

The analysis assumes that all track and the ruadbed beneath it are of the same quality, whether it is in a yard, little-used branch line, or on a high-density main line. While there are, in fact, tremendous differences in the quality of track, the replacement cost of track of various kinds is not so different as the condition of the track indicates. With this difference in mind, it is instructive to consider the optimum traffic per track-mile (density) for a railroad system from a cost standpoint. (The optimum level of output for a particular track endowment is defined technically as that for which short-run marginal costs equal long-run marginal costs.)

Assuming all traffic consists of freight tonnage, the optimum level of output can he shrown to be:

$$
Q^{*}=22.878 \mathrm{~T}^{0.992}
$$

where $Q^{*}$ is the optimum annual traffic in millions of tonmiles and $T$ is total track miles.

Th1s indicates that when used optimally, each mile of track would be passed over by an average of roughly 23 million tons annually for a small road and slightly less for a large road. This amounts to 10 to 12 freight trains per day, assuming an average of 80 cars per train. In general, most U.S. roads are operating at far less than their optimal level of output.

'l'he degree of underutilization of the current plant (or conversely, the degree of overbuilding present in the current railroad plant) is substantial. The Santa Fe, for example, should be carrying ruughly 440 billion gross-ton-uiles to achieve efficient utilization of its 20,000 miles uf Lrack. By contrast, its 1974 levcl of output was roughly 160 billion gross ton-miles (see Table 13).

The consequence of this underutilization (or overbuilding) is that the average costs of carriage exceed the minimum potential of the plant. Using equalion (2), the average cost per thousand ton-miles of moving 100 billion ton-miles should be rnighly $\$ 4.30$ (in 1971 dollars). By contrast, the industry average in 1972 was slightly under \$8 per thousand ton-miles.

Thua, the docline in the real average cost of rail carriage that has been observed over time is not the result of increasing return to scale (because the scale, or trackage, of the system has not changed significantly), but rather the efficiencies inherent in utilizing the 
Table 13

OPTIMAL TRACKAGE AND OUTPUT FOR SELECTED

CLASS I RAILROADS, 1974

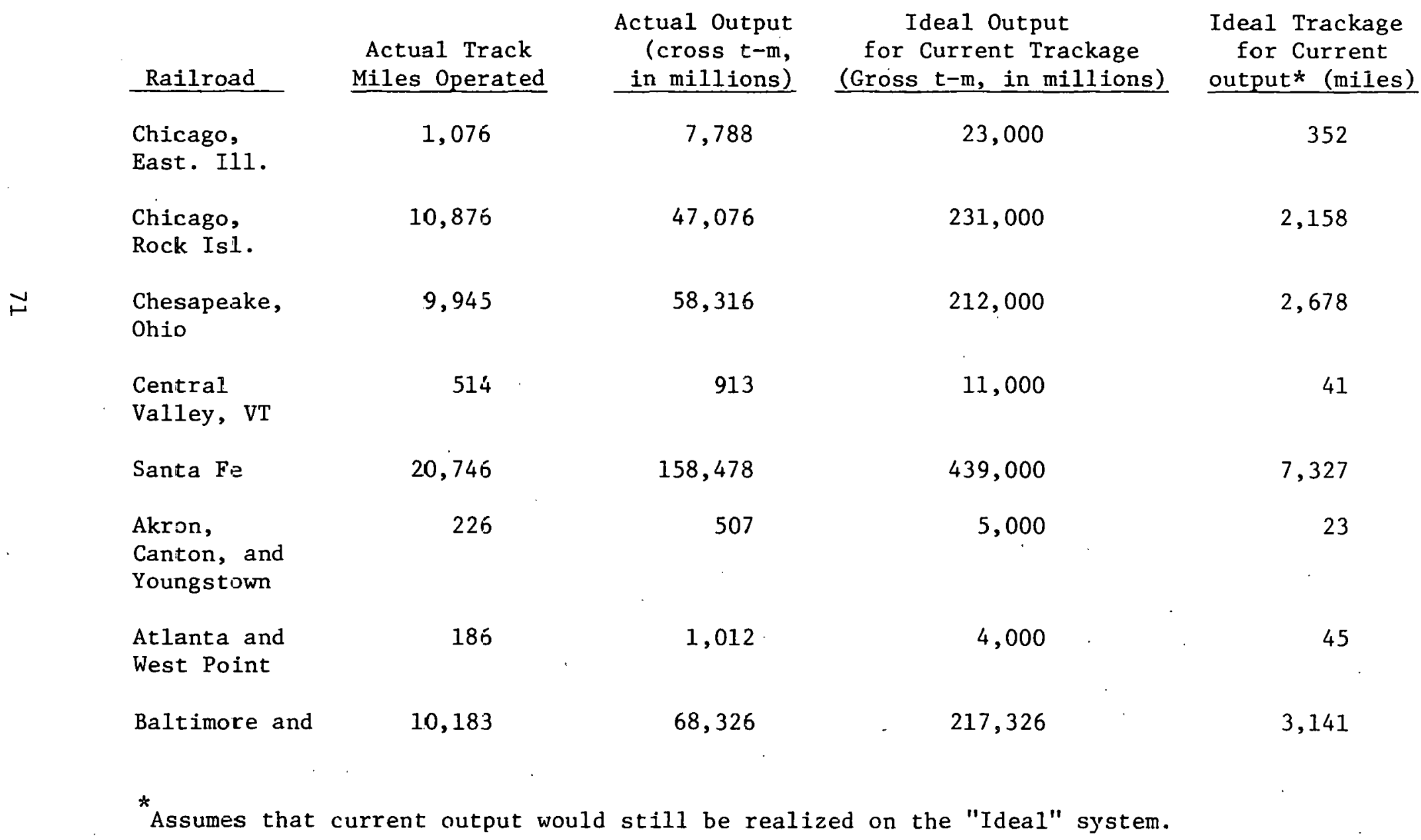


existing plant more efficiently. Since regulatory policy has limited roadway ábondonments, the railroads have substantia1 excess capacity; as traffic has grown over time, this capacity has been more densely utilized, and the amount that is "excess" has been reduced. Nonetheless, the losses that have occurred are substantial. If, for example, the 1972 level of traffic had been carried on a system of efficient scale (that is, at the long-run average cost), the savings would have amounted to about $\$ 3$ billion that year.

There is also the matter of technical efficiency--the ability of a railroad to operate its track endowment optimally. While most railroads have too great a capacity, the ability of a road to handle its given plant effectively varies considerably.

Figure 14 shows the relationship between short-run average costs and long-run average costs that have been calculated using formulae (1) and (2), assuming no passenger traffic.*

Assuming various fixed track endowments (200, 500, 100, 10,000 and $20,000)$, short-run average costs have been plotted. The long-run average cost envelope represents the unit cost of producing at various outputs when scale (trackage) is adjusted optimally.

Actual and predicted optimal unit costs are presented for a selected set of roads, illustrating both the excess capacity that exists (i.e., the roads are not operating near long-run average cost) and the technical inefficiency that may exist within the various roads (i.e., the divergence between predicted and actual unit costs). The fact that there is a divergence is not necessarily indicative of inefficiency on the part of the carrier. The simple cost relationships in equations (1) and (2) abstract from the diversity of rail operations. The special nature of some of their cervicco or opcrating characteristics may dictate costs higher or lower than the industry norm. However, large divergences probably portend basic problems in the area of operational er. lelency.

\section{Analyoic of Opcrating and System Differences}

l'he economic and energy consequences of public policy toward the railroads depends very much upon the type of services which the individual railroads are providing. The long-run average cost model that has been presented represents only the aggregate influence of simple

\footnotetext{
The amount of passenger gross-ton-miles carried by most roads is so small that this generalization is acceptable.
} 


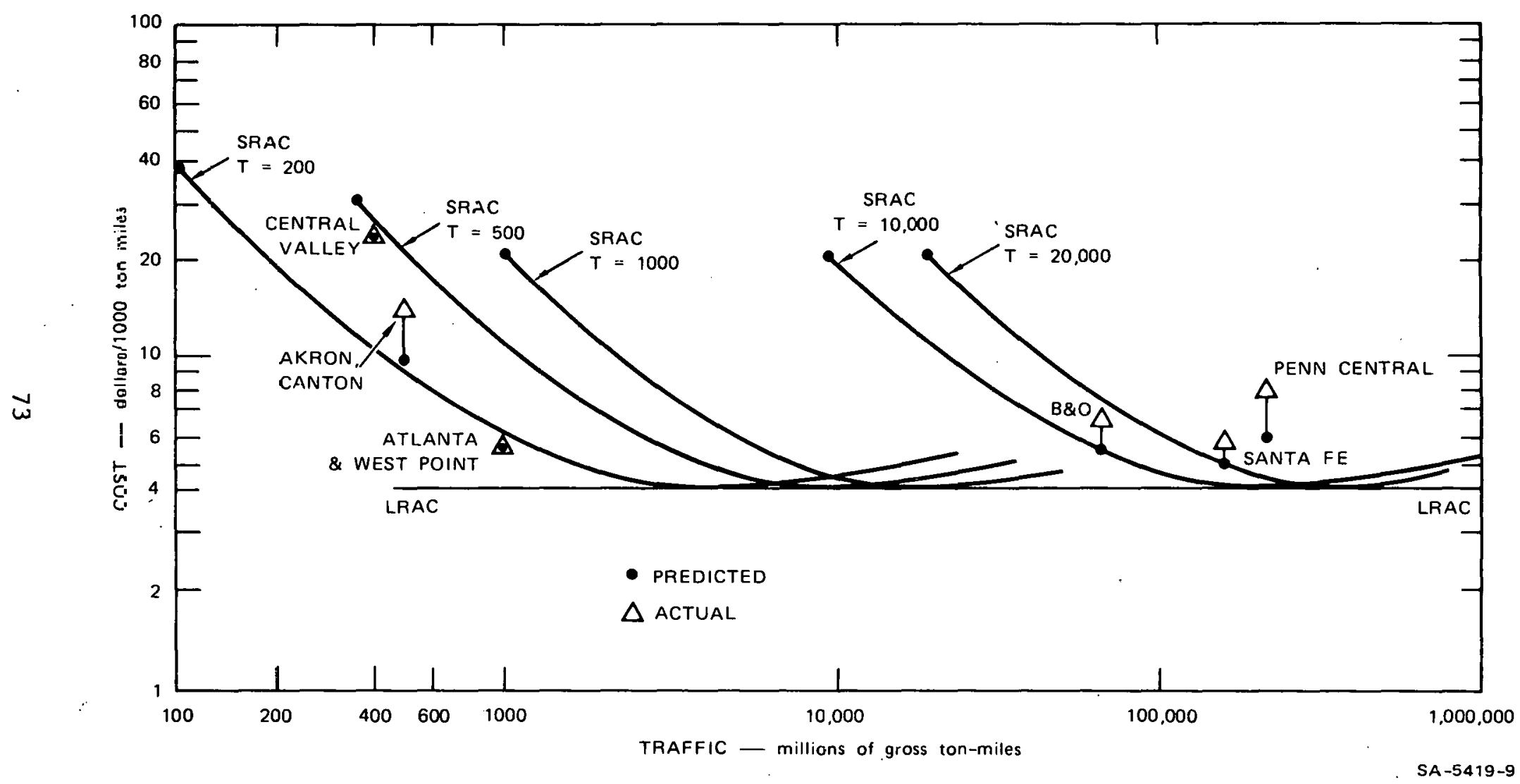

FIGURE 14 SHORT AND LONG RUN AVERAGE COSTS 
descriptors of railroad operations (output and scale) on the costs of operation. It does not relate the cost behavior of the railroad to a more detailed vector of operating characteristics.

To explore the detailed operating characteristics fully would require a complete simulation of the response of railroads to changes in operational characteristics as well as a simulation of changes in shipper responsiveness to new operational characteristics. As a cruder alternative, however, we have explored statistical methods of isolating the total effect of certain operational changes on the energy and cost experience of the railroads. Since these techniques permit use of aggregate data, they avoid somewhat the problem that disaggregation of data (allocations of cost to particular lines for example) may have been performed using arbitrary rules. On the other hand, because the data is aggregated, there are a limited number of hypotheses that can be explored with the available data.

\section{Statistical Cost Analysis}

The long-run average cost analysis indicates that U.S. railroad companies are not operating near long-run average costs because of chronic excess capacity, partly as a result of regulatory policy which limits abandonments. In addition, however, individual railroads do not all utilize the resources committed to the operation in identical ways. Because of different types of traffic and different types of operating conditions, individual railroads exhibit fairly wide-ranging unit cost and energy histories.

By exploring reásons for these deviacions, 1t is pussible to establish the importance of certain operational elements in the cost history of the individual carriers. This was accomplished by estimating the residual between the actual (1974) cost experience of a railroad and that forecast by the aggregate cost model. This residual was then correlated with the operational attributes that could be inferred from the aggregate (ICC report) data.

If an operational characteristic appeared to be important to explaining the observed "abnormality" in the cost experience of the carrier, it was included in a regression of the following form:

$$
\mathrm{R}=\mathrm{a}+\mathrm{bx}_{1}+\mathrm{cx}_{2}+\mathrm{dx}_{3}+\ldots
$$

where $\mathrm{R}$ is the percentage deviation from predicted total annual costs

$$
x_{1}, x_{2} \text {, etc., are operational characteristics. }
$$


Thus, the coefficients $b, c, d$, and so on can be interpreted as the percentage influence of the operational characteristic on the deviation of actual from predicted costs. The coefficient a is a constant term.

Table 14 illustrates the percentage contribution of some of the operational characteristics that were found to be correlated with the cost residual.

Table 14

EFFECT OF OPERATIONAL CHARACTERISTICS ON RAILROAD COSTS

Operational Characteristic

Train length

Yard and switching track/

Total trackage

Second main and passing track/

Total trackage

Empty car-miles/

Loaded car-miles
Percentage Effect on Costs

-0.00488 (statistically

not different from zero)

2.364

-0.0383 (statistically

not different from zero)

$-1.637$

The interpretation of the data in Table 14 is that, for example, having a high ratio of yard and switching track to total trackage tends to increase total costs above the predicted. A $1 \%$ increase in this ratio appeared to influence the deviation of costs by about $2.36 \%$. Note that neither train length nor the amount of extra "main" trackage appeared to influence costs significantly, but that it appeared to be cheaper to move empty cars than loaded cars. As the ratio of empty to loaded car-miles increases by $1 \%$, the ratio measuring deviation of actual costs from expected cusls decreased by about $1.64 \%$.

The fairly substantial influence of certain operational characteristics on railroad operating costs points out the potential usefulness of a cost model that has as its parameters as many of these characteristics as possible. Because of the limited amount of historical information available, however, the aggregate cost models which have been used in this research are confined to a limited set of descriptive variables. 
The relationship between operational characteristics and operating cost can be described more fully by working directly with their effect on the inputs to the railroad production process: labor and fuel.

Statistical Relationships between Operating Characteristics and Labor and Fuel Needs

The economic theory of railroad operations used by Keeler (Ref. 27) suggests that the demand relationships for labor and fuel are of the following mathematical form:

$$
E=a Q^{b} P^{c} T^{d}
$$

where $E$ is the demand for fuel per unit output

$Q$ is the level of output

$P$ is an index of relative prices $n f$ labor and fuel

$T$ is the total trackage of the railroad company

A similar relationship would exist for labor demand. The coefficients $b, c$, and $d$ may be interpreted as elasticities of demand for fuel.

The coefficients of these relationships can be estimated empirically from data in the ICC accounts. However, since $P$ is likely to be similar for all roads, it is not necessary to include it in the regression, and the level of demand for labor and fuel can be mcasured In dollar quantities rather than in simple units. Also, the coefficient " $a$ " is likely to be considerably different for railroads with different operational characteristics and might itself be a nonlinear function of these characreristics:

$$
a=e_{1}^{ \pm} x_{2}^{g} x_{3}^{h} \cdots
$$

Regressions of fuel and labor consumption of a $10 \mathrm{~g}-1$ inear form wers run on output, trackage, and various operational characteristics of the roads that were able to be proxied with measures contained in the ICC data. The results of these regressions are presented in Table 15.

These results illustrate the importance of considering the entire operation of the railroad when evaluating the effect of energy strategies rather than simply the dircrtly affuctud uupcces of Llie uperac1on. I'he observed relationships for the various operational characteristics are discussed below: 
Table 15

THE EFFECT OF OPERATIONAL CHARACTERISTICS ON

FUEL AND LABOR NEEDS OF CLASS I RAILROADS

PER FREIGHT TON-MILE

\begin{tabular}{|c|c|c|}
\hline $\begin{array}{c}\text { Operational } \\
\text { Characteristic }\end{array}$ & $\begin{array}{l}\text { E1asticity } \\
\text { of Fuel Use }\end{array}$ & $\begin{array}{l}\text { Elasticity } \\
\text { of Labor Use }\end{array}$ \\
\hline Gross ton miles & $\begin{array}{l}-0.0573 \text { (not statisti- } \\
\text { cally different from } \\
\text { zero) }\end{array}$ & -0.798 \\
\hline Track miles & $\begin{array}{l}0.118 \text { (not statisti- } \\
\text { cally different from } \\
\text { zero) }\end{array}$ & 0.810 \\
\hline $\begin{array}{l}\text { Average train } \\
\text { speed }\end{array}$ & -0.457 & -0.489 \\
\hline Load factor & -1.233 & -2.27 \\
\hline Train length & -0.570 & $\begin{array}{l}\quad 0.14 \text { (not } \\
\text { statistically different } \\
\text { from zero) }\end{array}$ \\
\hline $\begin{array}{l}\text { Ratio of yard and } \\
\text { switch track to } \\
\text { total }\end{array}$ & $\begin{array}{l}-0.135 \text { (not statis- } \\
\text { tically different } \\
\text { from zero) }\end{array}$ & 0.659 \\
\hline $\begin{array}{l}\text { Ratio of second } \\
\text { main and passing } \\
\text { track to total }\end{array}$ & $\begin{array}{l}0.112 \text { (not statis- } \\
\text { tically different } \\
\text { from zero) }\end{array}$ & $\begin{array}{l}\quad 0.12 \text { (not } \\
\text { statistically different } \\
\text { from zero) }\end{array}$ \\
\hline
\end{tabular}




\section{Gross-ton Miles}

Increasing gross ton-miles of a road appears to have no statistically significant effect on the fuel used per freight ton-mile. That is, there are no apparent energy advantages to having a railroad plant used more intensively on a simple gross ton-mile basis.

Increasing the gross ton-mile output would, however, offer potential savings in labor per freight ton-mile (the elasticity of labor use to gross ton-miles is -0.798 and significant). This suggests that much of the potential savings in cost from increasing the density of operations comes from more efficient use of labor. The coefficient suggests that (everything else held equal) increasing grnss ton-miles by $1 \%$ reduces labor use per freight ton-mile by $0.7 \%$.

\section{Track Miles}

Increasing the scale (track miles) of a railroad appears to offer no statistically significant energy savings per freight ton-mile. In fact the coefficient, while not statistically different from zero, is slightly positive, implying perhaps a slight energy disadvantage to large scale, everything else being equal.

Labor use per freight ton-mile, on the other hand, increases significantly with increases in scale, reflecting the labor intensity of excess trackage.

\section{Average Train Speed}

Increasing the average train speed (train-miles divided by train hours), reduces both the fuel and labor intensity of a freight ton-mile in a significant fashion. According to the estimated elasticities, a $1 \%$ increase in average train speed reduces fuel and labor use by 0.457 and 0.489 respectively. The result for fuel use is counter to the engineering result that higher speeds use more energy. This probably means that the trains roll more and idle less, but may also show that there are many other factors to consider in a complex system.

\section{Load Factor}

Increases in load factor have the expected very significant effect on fuel and labor intensity per freight ton-mile, reflecting the smaller amount of movement and handling that a ton-mile of freight requires and the reduction in the tare-to-net ratio. The coefficients are very large as anticipated, with a $1 \%$ increase in load factor offering a potential savings of $2.27 \%$ in the labor use per freight ton-mile. 


\section{Train Length}

Increases in train length have a beneficial effect on energy intensity, but the effect of train-length increases on labor utilization is not significant. In fact, the elasticity of labor use with respect to train length is positive (though not significantly so). This is a very likely result considering the additional labor effort that goes into handling and assembling a long train. The effects that these trains have on the capacity of yards, sidings, and other operational aspects may also "congest" other train operations, imposing new labor burdens elsewhere. This result also explains the net insignificance of train length with respect to total costs that was found in Table 14. While there are potential energy savings, these are offset by increased labor burdens at current prices.

\section{$\underline{\text { Ratio of Yard and Switch Track to Total Track }}$}

This measure is a very crude proxy for the amount of yard and switch activity that a road is involved in. While a more direct activity measure would be preferable, this one indicates that yard and switch activity are not, on balance, a major area of potential energy savings per freight ton-mile. In fact, while the coefficient is not significant, it is negative, implying that this activity may be energy saving because, perhaps, of more efficiently constituted trains or other factors. The labor component of this activity is significant, however, and the coefficient implies that a reduction of the yard and switch activity measure by $1 \%$ would reduce labor intensity per freight ton-mile by $0.659 \%$.

\section{Ratio of Second Main and Passing Track to Total Track}

The ratio of second main and passing track to total track is a very crude measure of the degree to which the railroad's system is configured in a fashion which permits two-way traffic and low-congestion train-passing otrategies. Tt also indicates that there are (or were) very high-density routes on the railroad. This element of train operations is not significantly related to either energy or labor use per freight ton-mile.

\section{Low-Density Lines}

The interest in relieving railroads of low-density lines as a cost saving hac led to a more dẹtailed investigation of low-density lines, using the firm approach. The analytical approach uses linedensity data to explore econometrically the relative influence of 
low-density operations on a railroad firm's total costs. While this approach was limited by quite severe data and analysis problems (described below), the tentative results were encouraging in that they suggested the magnitude of the problem for comparison with other analytical approaches.

The basic approach that was pursued by SRI in this area operated on the proposition that low-density railroad activities have an obvious, but two-way effect on total road costs:

- Low-density lines are not able to enjoy the economies of density inherent in railroad technology and are thus likely to impose substantially higher costs per unit output than a more densely utilized line.

- Low-density lines serve a valuable feeder function for the more densely utilized lines and are thus contributory to the dẹnsity of usage elsewhere on the system.

In order to formulate useful policy with regard to the abandonment issue, both of these effects must be quantified. In certain circumstances, it is possible that abandonment of low-density lines would create traffic losses for the remaining lines of such magnitude that average cost per ton-mile is not reduced, or is increased. While this may not be the most. likely consequence, it illustrates that there is some optimal abandonment strategy, when tariffs are regulated such that trackage should be abandoned until

$$
\partial \mathrm{C} / \partial \mathrm{L}=\partial \mathrm{R} / \partial \mathrm{L}
$$

that is, until the savings from abandoning another mile of low density track $(\partial \mathrm{C} / \partial \mathrm{L})$ are offset on the margin hy the losses in revenuc $(\partial \mathrm{R} / \partial \mathrm{L}) \mathrm{X}$. This is, of course, the optimizing view of the ratlroads and not necessarily of the rommunity as a wholc.

Tn order to explore this simple case, however, it is necessary to know the relationship between low-density trackage and traffic and high-density trackage and traffic and to relate these depentenries to cost and revenue generation.

In this context the railroad may be viewed as trying to manage jointly the production of two commodities, low-density service and high-density service. Assuming that both kinds of service can be provided in a Cobb-Douglass production manner, and further assuming that the railroad must serve all traffic presenting itself along the route at the regulated rates, the short-run total cost (SRTC) function can be sliown to be:

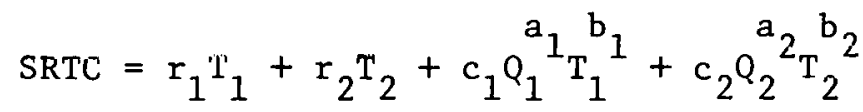


where $\mathrm{T}_{1}, \mathrm{~T}_{2}=$ single-track miles of track in low and high density service, respectively.

$$
\begin{aligned}
& \mathrm{r}_{1}, \mathrm{r}_{2}=\begin{array}{l}
\text { the fixed operating and capital costs per mile } \\
\text { of low- and high-density service respectively }
\end{array} \\
& \mathrm{Q}_{1}, \mathrm{Q}_{2}=\begin{array}{l}
\text { the output (in gross ton-miles) provided on low- } \\
\text { and high-density lines, respectively. }
\end{array} \\
& \mathrm{a}_{1}, \mathrm{a}_{2}, \mathrm{~b}_{1}, \mathrm{~b}_{2}=\text { parameters of the variable cost relationship }
\end{aligned}
$$

Ignoring the relationship between $Q_{1}$ and $Q_{2}$, this expression was econometrically parameterized using a sample of 23 firms for which line-density data was available from previous work in this study.* $\dagger$ A sample size this small makes the estimation method (Gauss-Newton nonlinear optimization) quite unstable and sensitive to the starting points for parameter values. The fewer the: observations, the more potential there is that the procedure will behave as if the equation system is underidentified, and it may yield quite disparate estimates of the parameters within the same standards of accuracy. $\neq$

Thus, the only regression that produced credible results was one that used Keeler's parameters. as starting values, but even this regression was unable to yield satisfactory estimates of the reliability of estimated parameters (Table 16).

The relative dimensions of $r_{1}$ and $r_{2}$ (and $c_{1}$ and $c_{2}$ ) indicates that a large proportion of the costs of operating branch lines are "fixed"

\footnotetext{
${ }^{*} Q_{1}$ and $Q_{2}$ are related because some of the low-density traffic becomes part of the movements on the high density portion of the system. Statistically speaking, this implies a linear correlation between two of the variables in SRTC. The effect of such correlation is to bias the estimates of the parameters, an effect that was observed in the regressions of the data on SRTC.

$+$

The trackage was classified as high-density if the annual ton-miles per mile was equal to or greater than 20 million. All other activity and track was allocated to the "low-density" category.

The procedure operates to find the vector of parameters which minimizes the sum of squared residuals between the observed and estimated values of SRTC.
} 
Table 16

PARAMETERS OF THE ESTIMATED SHORT-RUN TOTAT, COST RELATIONSHIP

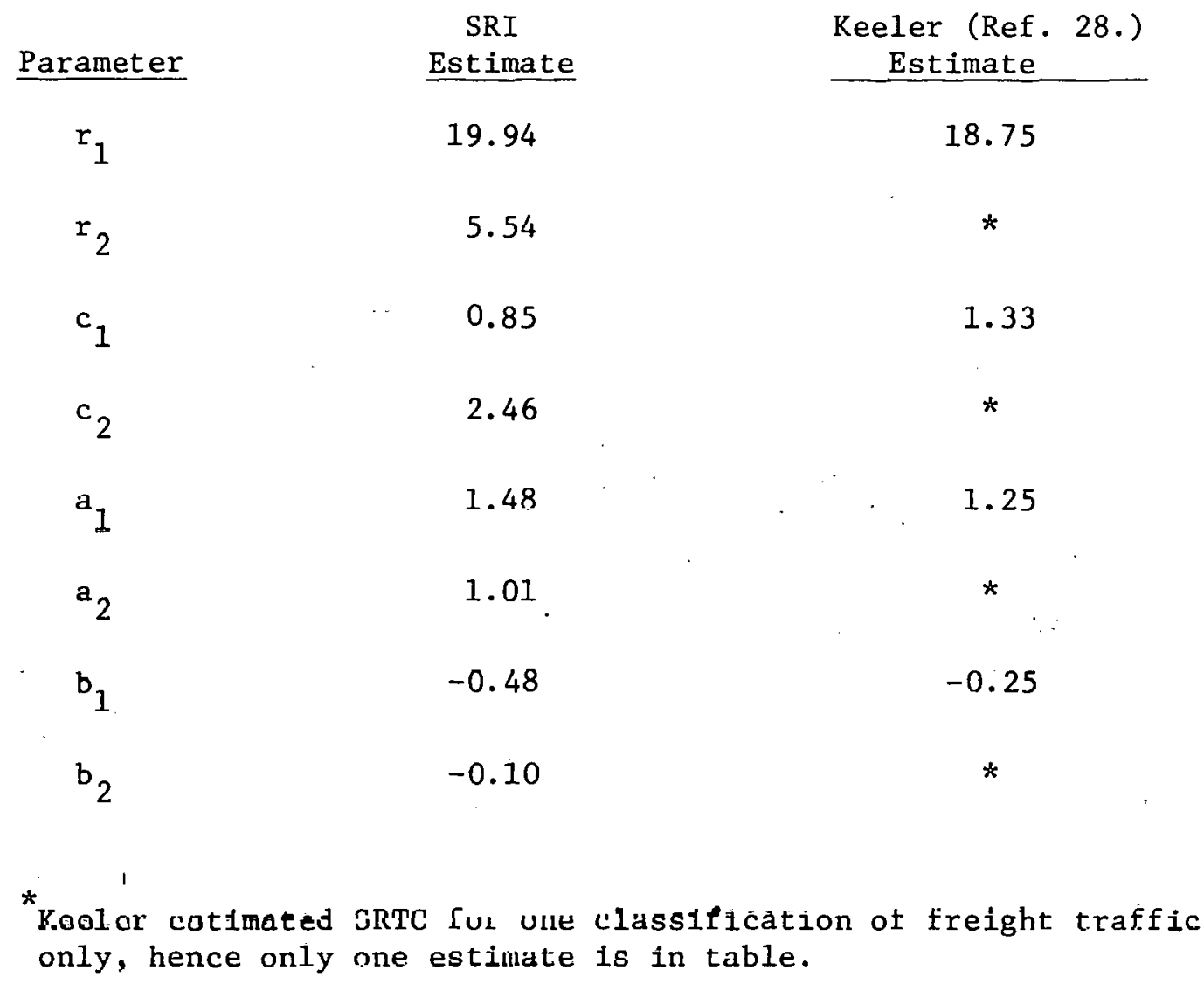

or Invariant with traffic. While we cannot rule out spurious econometric results at this point, it may be that more of the total costs of operating a mile of high-density line are variable with traffic than is possible with isolated, irregularly served low density lines.

The effect of this possibility is reflected in Table 17, which calculates the cost per track mile for each type of scrvice and the cost per ton-mile for each type of service. As expected, the cost per trackmile for densely used trarkage is much highcr than the less intensely utilized track, but because it is sprear nut over morc output, cost per gross ton-mile is lower. Table 1.7 also displays the morginal cost of output for each type of service and the "marginal benefit of abandonment." It should be noted that this latter measure is simply the short-run effect on cost of operating a plant with one less mile of 
Table 17

IMPLIED EFFECTS OF LOW-DENSITY TRACKAGE

\begin{tabular}{|c|c|c|c|c|c|c|c|}
\hline \multirow{2}{*}{$\begin{array}{c}\text { Density } \\
\text { of Service: } \\
\end{array}$} & \multicolumn{2}{|c|}{$\begin{array}{l}\text { Average Cost } \\
\text { per Track-Mi } \\
\left(\$ \times 10^{3}\right)\end{array}$} & \multicolumn{2}{|c|}{$\begin{array}{c}\text { Marginal Cost } \\
\text { per GTM } \\
\left(\$ \times 10^{-2}\right) \\
\end{array}$} & \multicolumn{2}{|c|}{$\begin{array}{c}\text { Average Cost } \\
\text { per GTM } \\
\left(\$ \times 10^{-2}\right) \\
\end{array}$} & \multirow{2}{*}{$\begin{array}{l}\text { Marginal Benefit } \\
\text { of Abandonment } \\
\left(\$ \times 10^{3}\right) \\
\frac{\text { Low }}{}\end{array}$} \\
\hline & High & Low & High & Low & High & Low & \\
\hline Road & & & & & & & \\
\hline Santa Fe & $\$ 41.7$ & $\$ 24.8$ & $\$ 1.51$ & $\$ 1.01$ & $\$ 1.72$ & $\$ 7.61$ & $\$ 17.59$ \\
\hline $\begin{array}{l}\text { Erie-LacKa } \\
\text { Wanna }\end{array}$ & 54.9 & 25.2 & 1.28 & 2.27 & 1.40 & 7.35 & 17.40 \\
\hline $\begin{array}{l}\text { Penn } \\
\text { Centra1 }\end{array}$ & 41.0 & 23.2 & 0.98 & 1.94 & 1.12 & 9.39 & 18.39 \\
\hline $\begin{array}{l}\text { Western } \\
\text { Pacific }\end{array}$ & 47.3 & 22.7 & 1.41 & 1.85 & 1.58 & 10.15 & 18.59 \\
\hline
\end{tabular}

low-density track and specifically does not account for other effects such as salvage value or the effect of the abandonment on traffic elsewhere in the system.

These estimates should all be regarded as illustrative of a possible method of evaluating low-density line abandonment rather than definitive results because of numerous problems which were encountered in the estimation process:

- The small-sample problem alluded to previously created convergence problems for the algorithm used to solve the estimation problem.

- If high-density ton-mileage does, in fact, generate highdensity line ton-mileage, $Q_{1}$ and $Q_{2}$ are correlated, leading to bias in the estimates of ${ }^{1}$ the parameters. The extent or existence of this bias can only be tested using more sophisticated models than the data would permit.

- The crude classification system ("high" versus "low" density) poses potential problems in estimation, which have not been addressed.

- The models' parameters could not be tested for significance because of convergence problems with the estimation procedure. 
THIS PAGE

\section{WAS INTENTIONALLY LEFT BLANK}




\section{RAILROAD ENERGY CONSUMPTION}

Types and Amounts of Energy Consumed

According to reports filed with the ICC for the year 1973, railroad locomotives consumed 4,144,212,598 gallons of diesel fuel, 434,920,463 $\mathrm{kWh}$ of electricity, 1,202 tons of coal. An additional 3,346,104 gallons of diesel fuel and $794,915,990 \mathrm{kWh}$ of electricity were used to power rail motorcars (Ref. 12). The distribution of these fuels consumed among freight, passenger, work trains and yard switching service is shown by the Table 18 . While these are reported as consumption, the totals are derived from purchases, estimates of inventory, and the use of estimating factors to determine the allocation of fuel to the various services. For example, yard switching fuel is estimated to be 7.5 gallons per switch engine hour as a result of a survey conducted for the ICC. This revises the previous estimate of 10.4 gallons per switch engine hour used in earlier reports. Passenger and work train allocations are derived from gross ton-mile figures in the services. Prior to the fuel shortages that occurred in 1973 and 1974 , fueling practices tended to result in significant amounts of spillage, and there may also have been some pilferage and loss due to rather lax controls on the stocks. Since the price of railroad fuel at that time was about 10 cents per gallon, the cost of more stringent controls was not justified. Thus, the allocated fuel consumption data does not take into account the difference between purchases and the amounts that were actually added to fuel tanks. Records of consumption of individual units are also rarely kept, since recording the unit numbers and amounts would be a clerical job at a location where there is not likely to be an employee of that craft available.

The railroads also used petroleum-based lubricants for locomotives; gasoline for highway vehicles and on- and off-track maintenance equipment; propane, fuel oil, natural gas, and coal for space heating and process heat; and electrical energy for lighting and air conditioning. Table 19 shows estimated consumption of these energy sources, extrapolated to 1973 consumption from 1971 reports (Ref. 30).

The equivalent heat content of the fuel $(137,300 \mathrm{Btu} / \mathrm{gal})$ and electricity $(11,278 \mathrm{Btu} / \mathrm{kWh})^{\star}$ used for traction results in an energy consumption of 575 trillion Btu for traction, compared with only about 20 trillion for gasoline-powered vehicles and lubricants and another 27 trillion for heating. Thus, traction is by far the largest consumer of energy in the freight railroad.

${ }^{*}$ Btu central station input to $\mathrm{kWh}$ at customer meter. 
Table 18

REPORTED FLEL CONSUNPTION BY CLASS I IINEHAUL RAILROADS, 1973

\begin{tabular}{|c|c|c|c|c|c|c|}
\hline & \multirow[t]{2}{*}{ Service } & Used in D-esel & Lccomotives & $\begin{array}{l}\text { Used in Other } \\
\text { Locomotives (steam, } \\
\text { turb ine, e=c.) }\end{array}$ & \multicolumn{2}{|c|}{ Used in Rail Motorcars } \\
\hline & & $\begin{array}{l}\text { Diesel Fuel } \\
\quad \text { (gal) }\end{array}$ & $\begin{array}{l}\text { Electricity } \\
(k W \ldots) \\
\end{array}$ & (tons) coal & $\begin{array}{l}\text { Diesel Fuel } \\
\text { (gals) } \\
\end{array}$ & $\begin{array}{l}\text { Electricity } \\
(\mathrm{kWh})\end{array}$ \\
\hline & Freight & $3,664,731,863$ & $321,545,113$ & & & \\
\hline & Passengər & $78,516,594$ & $109,702,726$ & 1.154 & $3,346,104$ & $777,915,703$ \\
\hline a & Yard switcining & $385,055,164$ & $3,464,112$ & & & $17,00 \mathrm{~J}, 287$ \\
\hline & Work train & $15,908,97 T$ & $20 \cdot 3,512$ & 48 & -- & -- \\
\hline & Tota1:3 & $4,14 c, 212,598$ & $434,920,463$ & 1,202 & $3,346,104$ & $794,915,990$ \\
\hline
\end{tabular}

Source: Ref. 12. 
Table 19

MISCELLANEOUS FUELS, ENERGY AND PETROLEUM

PRODUCTS USED BY RAILROADS, 1973

Item

Estimated Consumption

Equivalent Energy

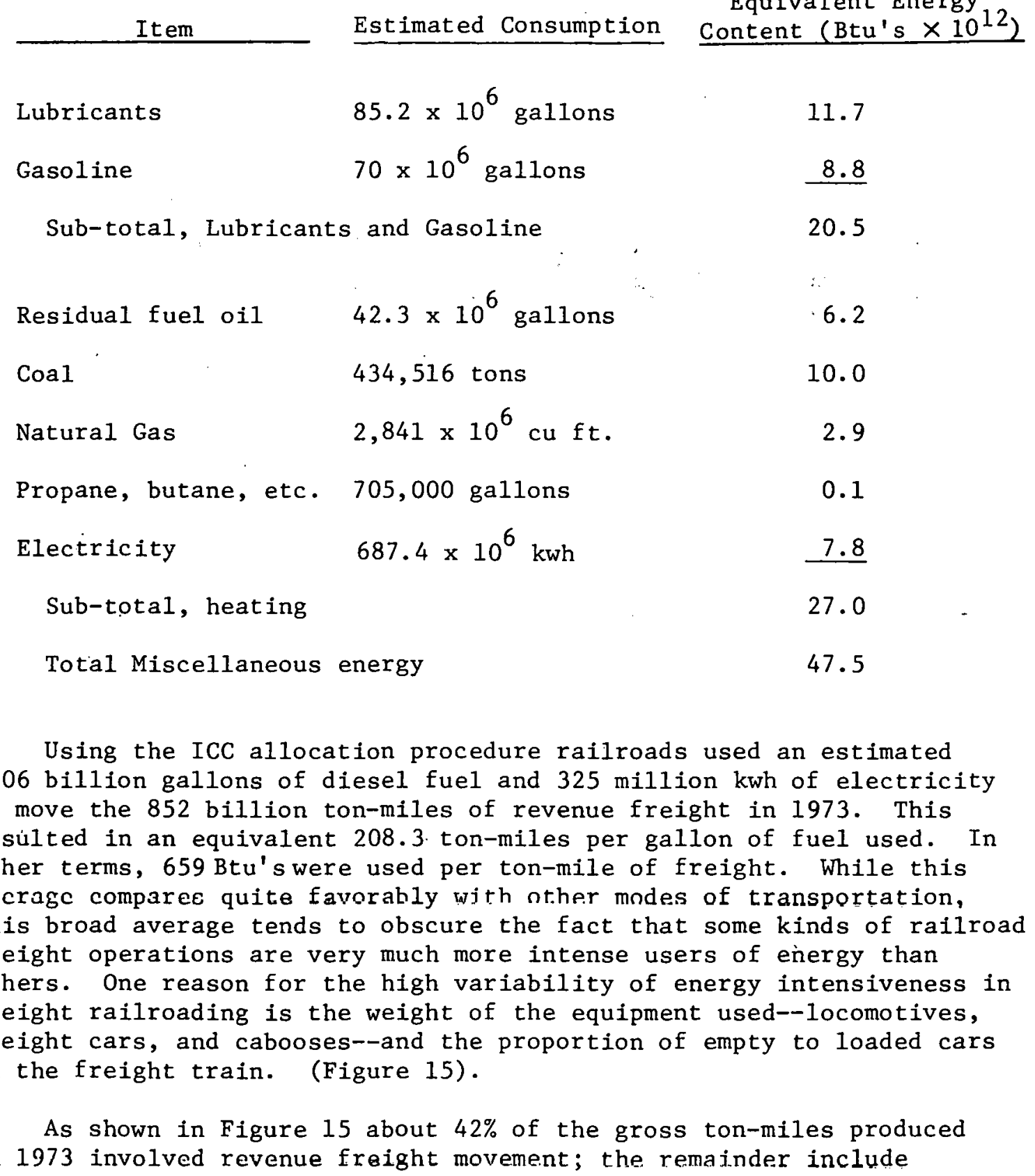




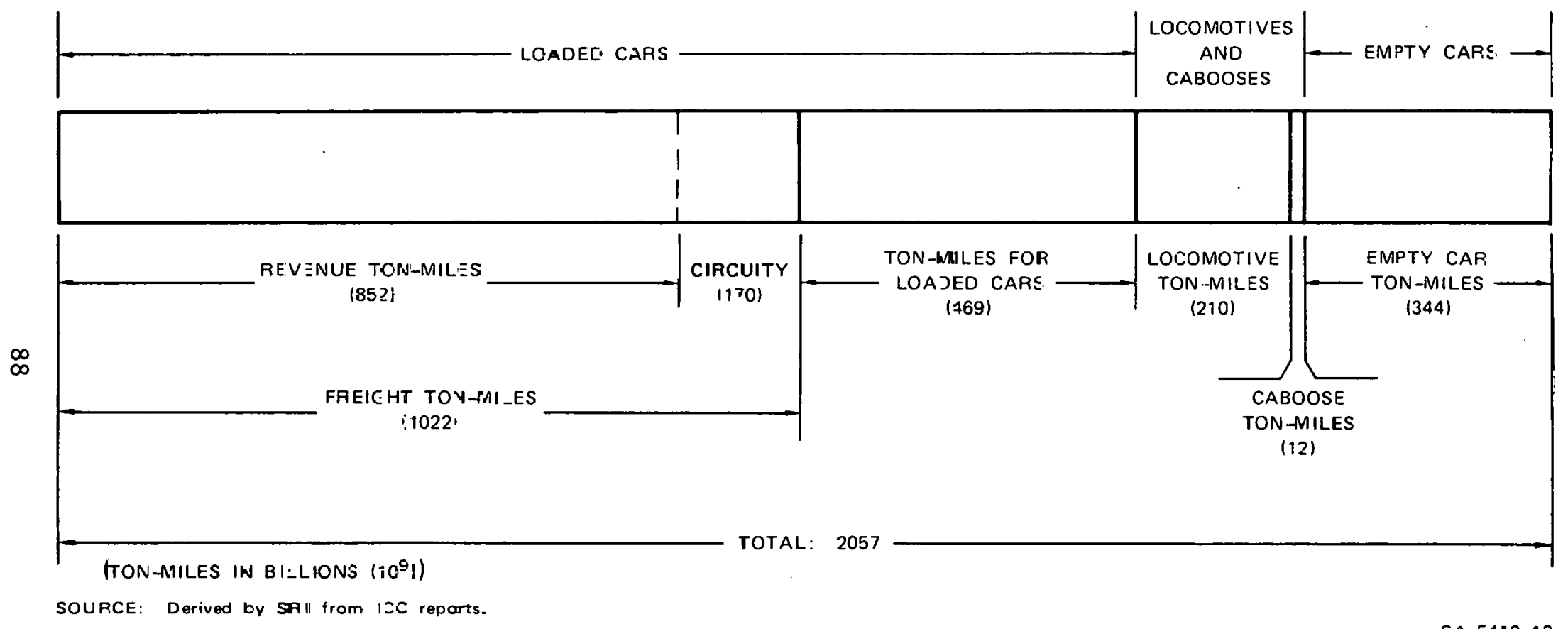

IFIGUPE 15 DISTRIBUTION OF RAILROAD TON-MILES: 1973 FREIGHT SERVICE 
circuity of haul* and haul of empty and loaded freight cars, locomotives, and cabooses.

Since energy consumption is related to the ton-miles of work performed, the figure approximates the distribution of energy used in road haul operations. The proportion of energy used to move railroad equipment (loaded and empty freight cars, locomotives, and cabooses) is about half of the total.

To show further how different freight operations consume vastly differing amounts of fuel, the energy consumption of freight trains was analyzed, and fuel computations accompany the cost computations described in Section IV. The development of the fuel estimating procedure is described in Appendix B. In genera1, the method estimates the work done to overcome resistance of the train, then computes the fuel necessary to produce this amount of work through the locomotive.

Train resistance has components from movement over level, tangent track, and from increased resistance because of curvature in the track, grades, and decelerations. Resistance while moving over level track results from small deflections of the track structure under the wheels, from joints, from the action of wheel flanges rubbing against the gage side of the rails, and from air resistance. Grades require additional work to raise the train, but this work is recovered by trains traveling in the opposite direction, unless braking is required to keep the train speed within acceptable limits. Thus, braking energy is computed as the energy consumed in the braking process, in addition to the work required to lift directionally unbalanced freight flows along the line. Curvature of the track adds to the pressure of the flanges against the gage side of the rail, thus increasing friction and resistance.

Finally, stopping or slowing the train dissipates energy that must be replaced with work done by the locomotive.

Using the methods developed in Appendix B, aggregate energy consumption has been analyzed, as shown by Tables 20 and 21 .

To help understand where this energy might be allocated, consider the values tabulated in Table 21 .

\footnotetext{
${ }^{*}$ Circuity--difference in distance between the most direct route and the route by which the car is actually directed to move. A car is often shipped farther because the company can collect greater. rovenue by keeping it on its own property,
} 
Table 20

ESTIMATION OF FUEL ALLOCATION FOR ALL U.S. FREIGHT

RAILROAD OPERATIONS, 1973

\begin{tabular}{|c|c|c|}
\hline Item & Amount & Source \\
\hline $\begin{array}{l}\text { Reported nationwide fuel consumption } \\
\text { (road units) }\end{array}$ & $3,665 \times 10^{6} \mathrm{gal}$ & Ref. 12 \\
\hline $\begin{array}{l}\text { Equivalent fuel for electrical power } \\
\text { used for traction }\end{array}$ & $27.4 \times 10^{6} \cdot \mathrm{gal}$ & * \\
\hline $\begin{array}{l}\text { Estimated spillage unaccounted for } \\
\text { Total fuel consumed }\end{array}$ & $\begin{array}{r}367 \times 10^{6} \mathrm{gal} \\
3,325 \times 10^{6} \mathrm{gal}\end{array}$ & SRI estimate \\
\hline $\begin{array}{l}\text { Allucallun of ruel } \\
\text { Idle time, } 148.8 \times 10^{6} \mathrm{hr} \\
\text { fuel } 5 \text { gal } / \mathrm{hr}\end{array}$ & $744 \times 10^{6}$ gal & + \\
\hline $\begin{array}{l}\text { Traction work, } 2,057 \times 10^{9} \\
\text { ton-mi o } 6 \mathrm{lb} / \text { ton resistance }\end{array}$ & $\begin{array}{l}32.5 \times 10^{12} \\
\text { f.t-tons }\end{array}$ & Ref. 12 \\
\hline $\begin{array}{l}\text { Traction fuel e } 0.06 \mathrm{gal} / 1000 \\
\text { ft-tons }\end{array}$ & $1,949 \times 10^{6} \mathrm{ga} 1$ & \\
\hline $\begin{array}{l}\text { Allocated to grade, curve, accelera- } \\
\text { tion, and higher specific fuel } \\
\text { congumption }\end{array}$ & $632 \times 10^{6} \mathrm{gal}$ & \\
\hline $\begin{array}{l}* 321,5 \times 10^{6} \mathrm{kWh} \text { of electrical encrgy } \\
\text { services. This was converted to gal } \\
\text { Btu of central station input per kWh } \\
\text { value of } 137,300 \text { Btu per gallon. Th } \\
\text { per kWh converts the electrical ener }\end{array}$ & $\begin{array}{l}\text { s used fur tracll } \\
\text { s of fuel at the } \\
\text { the driver, and } \\
\text { esulting factor } \\
\text { consumed to } 27.4\end{array}$ & $\begin{array}{l}n \text { in road } \\
\text { ate of } 11,700 \\
\text { fuel heating } \\
0.085 \text { gallons } \\
10^{6} \text { gallons. }\end{array}$ \\
\hline $\begin{array}{l}\text { Idling time assumed at twice the } \\
\text { motives. Number of locomotives per } \\
\text { ICC stat1stics of locomotive unit-mi } \\
\text { train-hours in freight service of } 2.5 \\
\text { time of } 148.8 \times 10^{6} \text { hours. }\end{array}$ & $\begin{array}{l}\text { ting time esti } \\
\text { and was computed } \\
\text {, non resulted }\end{array}$ & $\begin{array}{l}\text { for } 10 c 0- \\
2.9 \text { from } \\
\text { Reported } \\
\text { an idling }\end{array}$ \\
\hline
\end{tabular}


Table 21

SENSITIVITY OF FUEL CONSUMED TO INCREMENTÁL VALUES OF CURVATURE, ACCELERATION, AND GRADE FOR U.S. FREIGHT RAILROADS IN 1973

\begin{tabular}{|c|c|c|}
\hline Train Resistance Source & Increment & Fuel Consumed per Increment \\
\hline Curvature & $10 \% \mathrm{mi}$ & $49 \times 10^{6} \mathrm{gal}$ \\
\hline Acceleration & $\begin{array}{l}\text { One acceleration } \\
\text { to } 30 \mathrm{mph} / 100 \\
\text { tra1n-mi }\end{array}$ & $37 \times 10^{6} \mathrm{ga} 1$ \\
\hline Grade over $0.3 \% / \mathrm{mI}$ & $0.01 \% / \mathrm{mi}$ & $65 \times 10^{6} \mathrm{gal}$ \\
\hline $\begin{array}{l}\text { Increased specific } \\
\text { fuel consumption }\end{array}$ & $\begin{array}{l}0.005 \text { gallons } / 1000 \\
\mathrm{ft} \text {-tons }\end{array}$ & $163 \times 10^{6} \mathrm{ga} 1$ \\
\hline $\begin{array}{l}\text { Increase in train } \\
\text { speed }\end{array}$ & $4 \mathrm{mph}$ & $271 \times 10^{6} \mathrm{gal}$ \\
\hline
\end{tabular}

The total of all these values would account for approximately the amount of fuel shown at the bottom of Table 20. In the table, values for curvature and acceleration are considered to be smaller than those actually encountered. The variation of specific fuel consumption and resistance of the train are about $10 \%$ of the nominal values. On the other hand, an average $0.01 \% /$ grade mi (over $0.3 \%$ ) might be considered high as a nationwide average. The table illustrates the sensitivity of fuel consumption to various factors. The fuel consumption appears to be especially sensitive to assumptions about train speed.

\section{Energy Computations in the Models}

The models that describe the cost behavior of railroad switchyards, local delivery, and linehaul operations also include computations of fuel required for each operation. These computations are, in the case of the mainline and branch line models, subroutines in the computer programs which calculate the fuel requirements based upon the fuel estimating model described in Appendix $B$. In the case of the switchyard model the fuel is calculated as a function of switch engine hours. 
Fuel Used in Mainline Operations

The mainline component of the model has been run several times to determine the sensitivities of fuel consumption to various input parameters. The fuel model appears to be most sensitive to changes in speed. While this result is somewhat expected it will be seen in the summary of branch line model results that the main line model is more sensitive to speed changes because more time is spent with the trains running at the speed, and no time is spent idling or switching cars. Fuel consumption versus speed is shown by Figure 16. The figure shows that the slower the average train speed the less fuel per net ton-mile used. These results hold only for the road haul portion of our abstracted segment of the railroad company.

Another interesting result of the ear1y runs of the model 18 shown in Figure 17. This figure depicts the sensitivities of the fuel consumption to ratio of empty to loaded cals. As expected, the fewer the number of empty cars hauled the better the fuel consumption. The same figure also shows the cost per net ton-mile for different load ratios.

\section{Fuel Used in Branch Line Operations}

Several early runs of the branch line component of the model have yielded some interesting results. The model shows that much of the time on a trip along the line is spent switching cars into and out of customer sidings. The locomotive is operating at idle power during most of this time, so a large part of the fuel used is in this idle mode. On the other hand, the fuel per net ton-mile of frcight service does decline with train length, indisating, as expected, that the larger the number of cars in the train, the smaller the proportion of the tocal load represented by the locomotive and the caboose. Because the cars in the train must wait while the switching is being done, the capital cost of the cars pushes frequencies up and train lengths down in order to achieve minimum costs. The energy consideratinns, howover, tend to favor longer trains in this part of the operation. Figure 18 illustrates the cost and energy variations in this kind of service for several annual tonnages and lengths of haul. The figure shows a significant reduction in fuel per ton-mile for the longer haul, indicating that there is a large component of the fuel consumption that is not increasing with distance. It also shows the cost minimum fur 100,000 tons per year at a train length or about six loaded cars per train. (The model also includes the same number of empties in the crain.) 

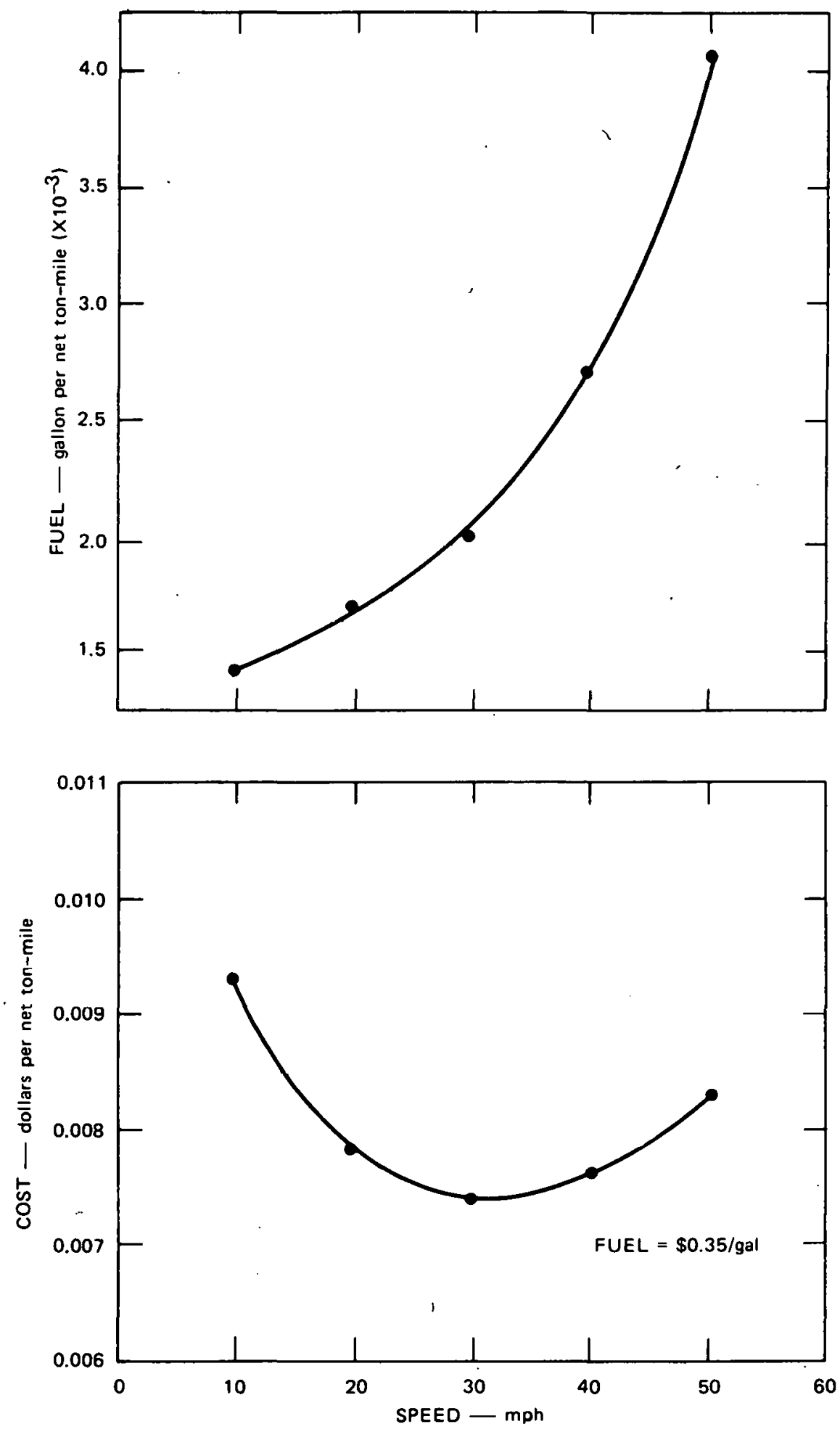

NOTE: All curves for $20 \times 10^{6}$ net annual tons 500-mile line.

SA-5419-17R

FIGURE 16 MAINLINE COMPONENT FUEL AND AVERAGE COST VERSUS SPEED 

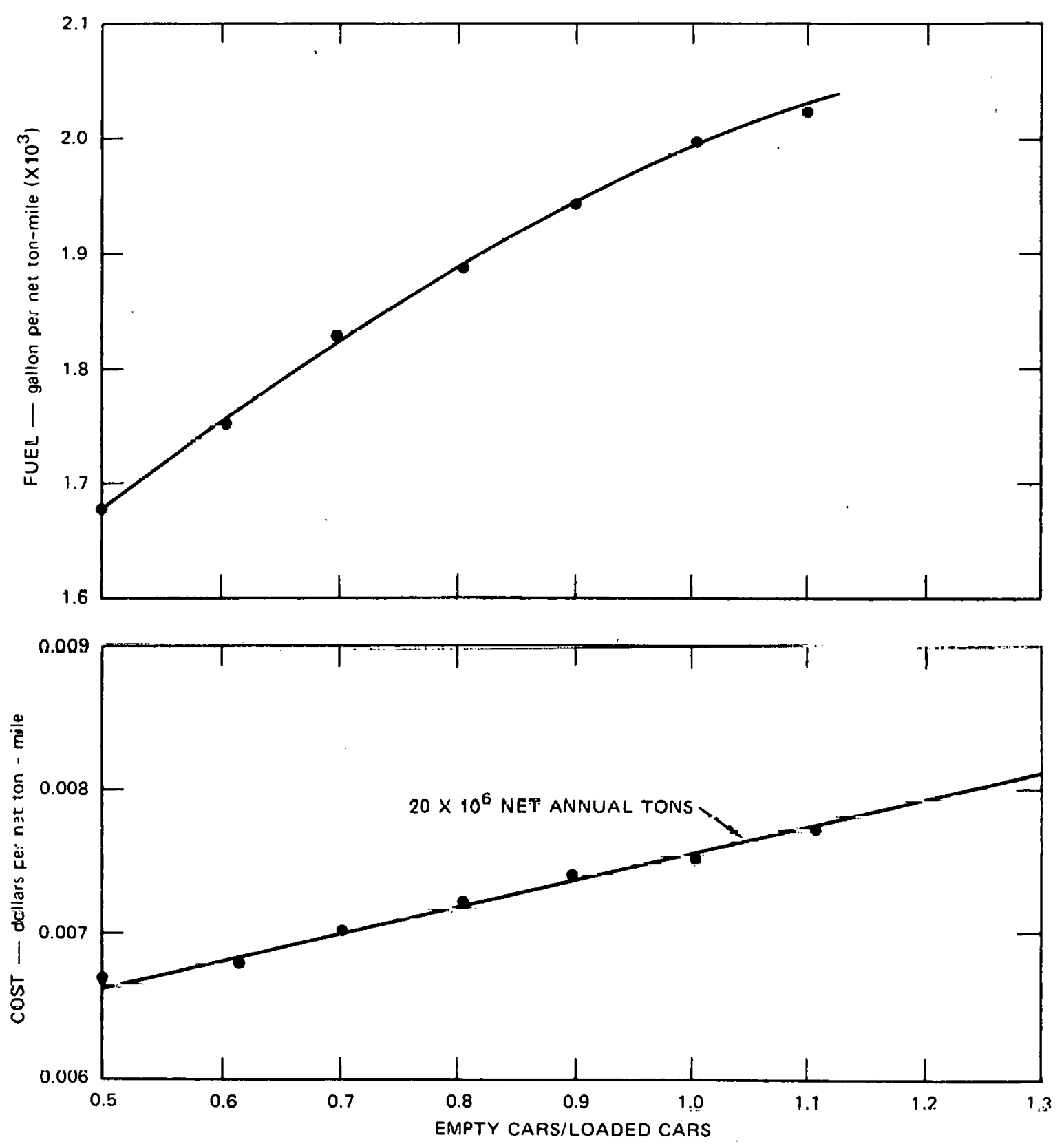

NOTE: Figures drawn for $30 \mathrm{mph} 500-\mathrm{mile}$ line:

SA-5419-18R

FIGURE 17 MAINLINE COMPONENT FUEL AND AVERAGE COST VERSUS EMPTY TO LOADED CARS RATIO 


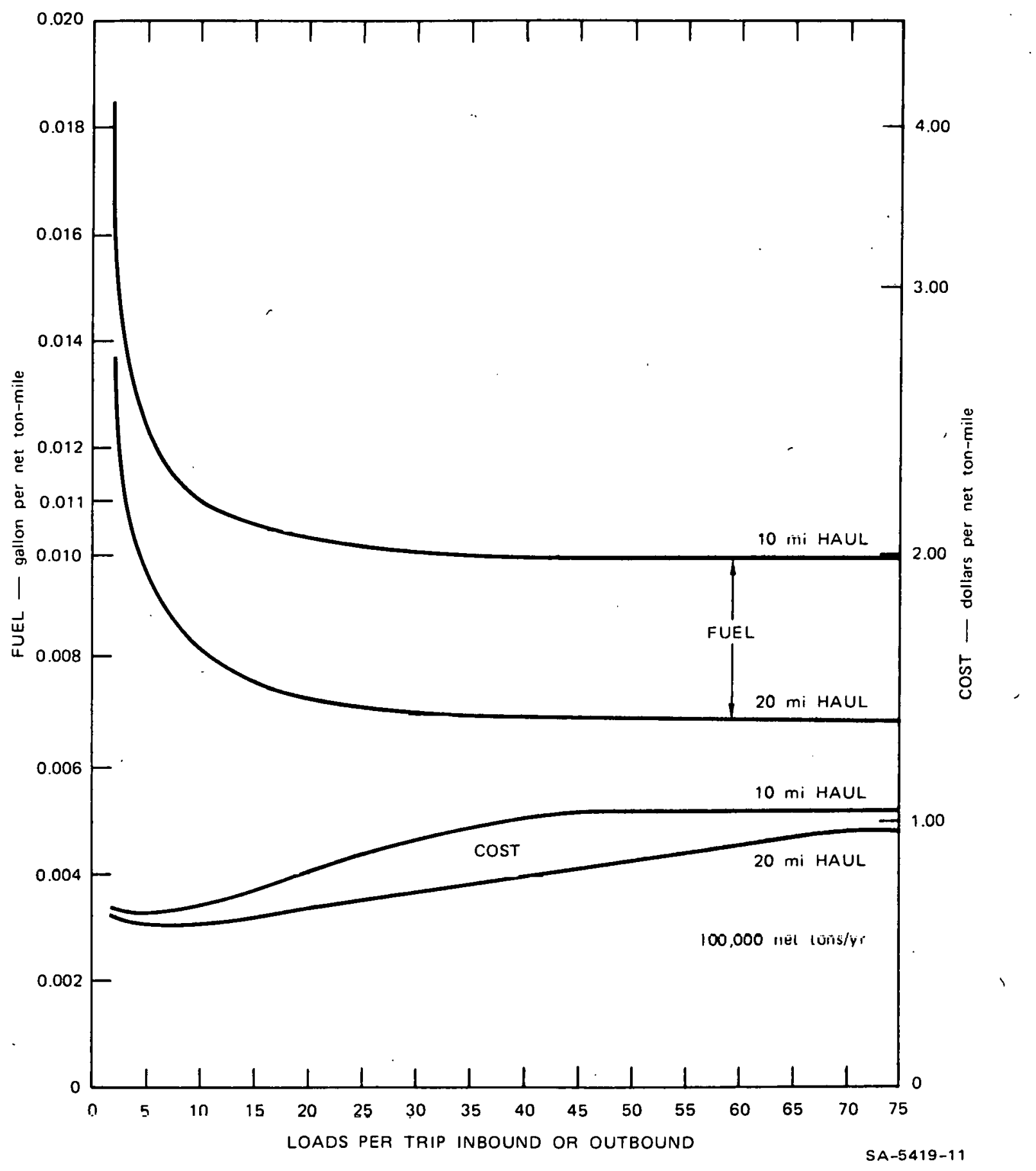

FIGURE 18 WAY SWITCHING TRAIN VARIATION OF AVERAGE COST AND FUEL CONSUMPTION WITH TRAIN LENGTH 
With this short train, the fuel per ton-mile is significantly higher than that required for longer trains.

A sensitivity analysis to determine the effect of an increase in fuel price was conducted. Increasing the fuel price by a factor of about three did not change the length of train for minimum cost because of the large component of fuel burned during the switching time of each car. Increase in the average cost per ton-mile was about $1 \%$ for this operation.

\section{Switchyard Fuel Consumption}

The model for switchyards determines the fuel requircd for the switchyard by determining the number of switch engine-hours per car dispatched and using a factor of 7.4 gallons per engine-hour as the estinated fuel consumption. The complexity of yard operations did not allow any more refined analysis than this.

\section{Investment of Energy in Railroad Facilities}

In addition to fuel used in propelling locomotives, a significant amount of energy is contained in the manufacture of the equipment and in construction facilities. Methods have been developed to relate energy consumption of industries to thcir production levels in dollars, using techniques similar to the input-output analysis of the economy.

The syetem energy totals are impurtanc only in that they Indicate the amount of energy that might be salvaged from the system and that they give an indication of what would be required to replace the system. Unll energy content shows the impact of changing the size of the system or replacing units. The system total of abnut $10 \times 10^{15}$ is about 20 times the annual energy consumption for traction.

The table uses two different methods of energy accounting, energy content of physical units, and energy content per dollar. Physical unit values were obtained from Reference 12, and Btu per dollar values were obtained from Reference 31. Energy content per unit of output was estimated in Reference 32. 
Táble 22

ENERGY CONTENT OF VARIOUS RAILROAD COMPONENTS

\begin{tabular}{|c|c|c|c|c|}
\hline Item & Unit Value & Unit Energy & System Energy Content unit & Total \\
\hline Track & $\begin{array}{l}200 \text { tons } / \\
\text { track-mi }\end{array}$ & $\begin{array}{l}52.7 \times 10^{6} \mathrm{Btu} / \\
\text { ton }\end{array}$ & $10.54 \times 10^{9} \mathrm{Btu} / \mathrm{mi}$ & $3,463 \times 10^{12}$ Btu \\
\hline $\begin{array}{l}\text { Grading and } \\
\text { Roadjed }\end{array}$ & $\$ 200,0 J 0 / \mathrm{mi}$ & $\begin{array}{r}100,000 \mathrm{Btu} / \\
\$ 1.635\end{array}$ & $12.23 \times 10^{9} \mathrm{Btu} / \mathrm{mi}$ & $2,446 \times 10^{12} \mathrm{Btu}$ \\
\hline Locomotives & $\$ 360,010 /$ e.ach & $\begin{array}{l}54,421 \mathrm{Btu} / \\
\$ 1.229\end{array}$ & $15.94 \times 10^{9} \mathrm{Btu} /$ unit & $443 \times 10^{12} \mathrm{Btu}$ \\
\hline Freight cars & 26 tons/each 1 & $\begin{array}{l}52.7 \times 10^{6} \mathrm{Btu} / \\
\text { ton }\end{array}$ & i. $37 \times 10^{9} \mathrm{Btu} / \mathrm{car}$ & $2,361 \times 10^{12}$ \\
\hline
\end{tabular}




\section{THIS PAGE}

WAS INTENTIONALLY

LEFT BLANK 
Appendix A

CORRIDOR NETWORK DESCRIPTION 


\section{THIS PAGE}

WAS INTENTIONALLY

\section{LEFT BLANK}




\author{
Appendix A \\ CORRIDOR NETWORK DESCRIPTION
}

\title{
I. Introduction
}

This section contains a description of the physical characteristics of the portion of the national railroad network which has been included in our data base. It also contains a record of the criteria for selection of the various elements of the network. The main line description can serve as the input data base for the economic and energy models of main line operation.

\section{Basic Elements of Input}

\section{Physical Characteristics}

The process of describing the corridor portion of the U.S. railroad network involves establishment of criteria for selection of corridors and connecting track, selection of railroad companies using the corridors, and (for computer processing) the selection of nodes, (locations) along each corridor.

The first step in the process was the definition of city pairs that represented major centers of traffic origin and destination. As described previously, the pattern of railroad operations consists primarily of a collector network, industrial switchyards, a connective network, major classification yards, and major trunklines. Figure A-1 shows a sketch of the major trunklines in the country. Data for the northeast were obtained from USRA's Preliminary System Plan (Ref. 33). Data for western states is from an exhibit supporting a study of railroad competition in western states that was related to the merger application of the Union Pacific and the Rock Island. Data for the southeastern and Mississippi River areas were obtained from the Department of 'Iransportation Zone Maps (Ref. 16). The figure shows trunk track in the corridor description as solid lines and connector track as dashed lines.

The city pairs listed in Table A-1 are shown in Figure A-1. 


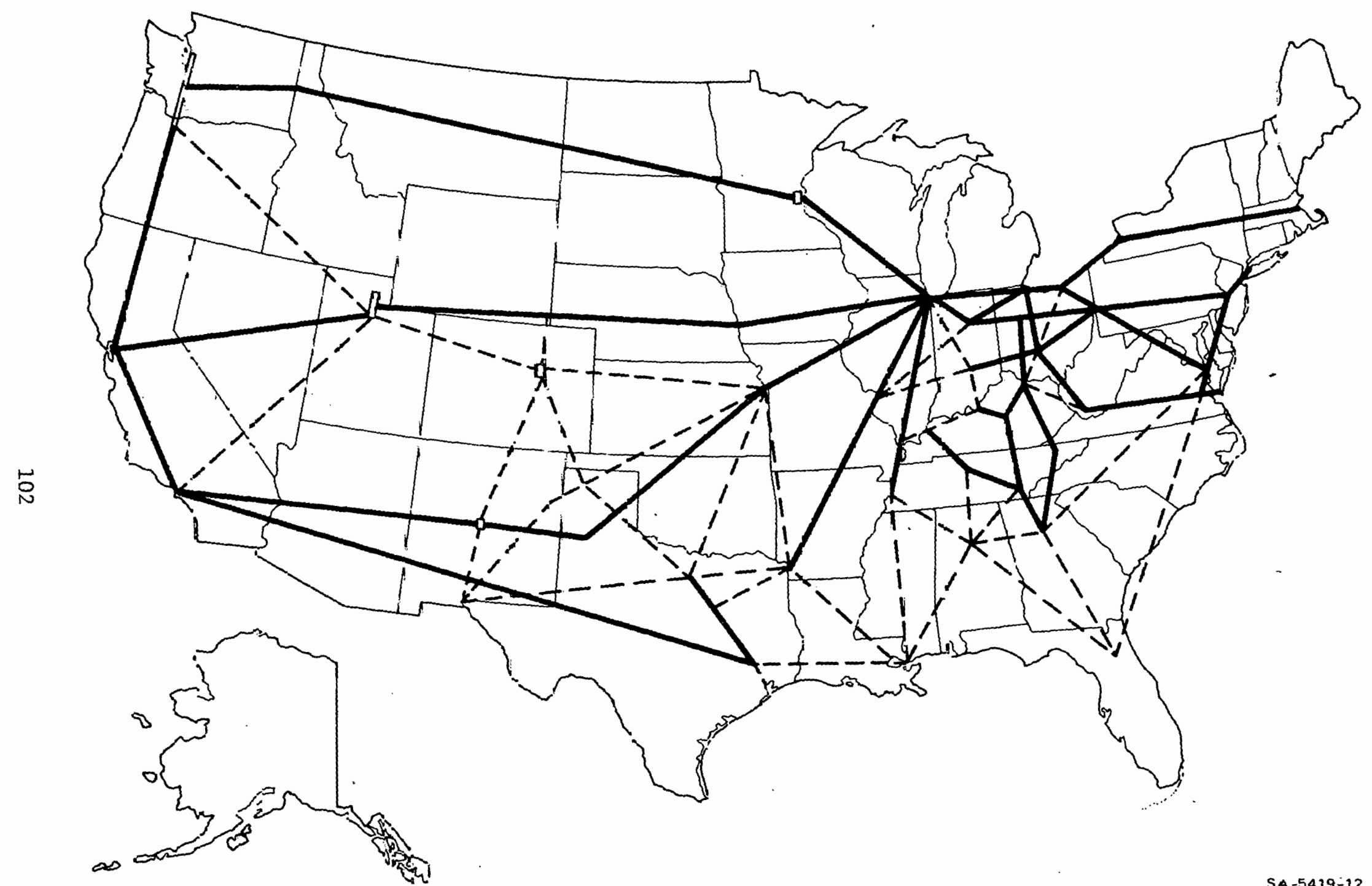

FIGURE A-1 NATIDNWIDE TRUNK AND CONNECTING RGILROAD LINES 
Table A-1

LIST OF CITY PAIRS CONSTITUTING MAJOR TRUNK AND CONNECTING LINES IN THE UNITED STATES

Between

Los Angeles
San Francisco
Los Angeles
Los Angeles
Los Angeles
San Francisco
Portland/Seattle/Tacoma
Portland/Seattle/Tacoma
Salt Lake/Ogden
Denver/Cheyenne
E1 Paso
Amarillo
Denver/Cheyenne
El Paso
Ft. Worth
El Paso
Houston
Dallas/Ft. Worth
Denver
Omaha
Kansas City
Kansas City
Minneapolis
St. Louis
St. Louis
Chicago
Chicago
Ft. Wayne
Toledo
Indlanapolis
Toledo
Toledo

Cleveland

Cleveland

Pittsburgh

Parkersburg, W. Va.

Pittsburgh

Washington

Philadelphia

Schenectady

Sclientiect ady

Washington

At lanta

New Orleans

New Orleans

Memphis

Cincinnati

Cincinnati

Louisville

At lanta

Knoxville

$\Lambda$ tanta

At lanta

At lant a

Birmingh am

Dilüingliam and

San Francisco

Port land/Seatt le/Tacoma

E1 Paso

Ogden/Salt Lake

Amarillo via Santa Fe

Ogden/Salt Lake

Ogden/Salt Lake

Minneapolis via Spokane

Omaha, via Denver/Cheyenne

E1 Paso via Santa Fe

Kansas City via Tucumcari

Kansas City via Lubbock

Ft. Worth via Lubbock

Ft. Worth via Lubbock

Houston

Houst on

Dallas/Ft. Worth

St. Louls

Kansas City

Chicago

Chicago

St. Louis

Chicago

Ft. Wayne

Indianapolis

Toledo

Pittsburgh via Ft. Wayne

Cleveland

Cleveland

Columbus

Cincinnat 1

Parkersburg W. Va, via

Columbus

Pittsburgh

Schenectady via Buffalo

Ph1ladelphia

Richmond via Roanoke

Washington, D.C.

Philadelphia

Jersey City

New York

Boston

Jacksonville

Jacksonville

Houston

Memphis

Chicago

Chat tanooga

Louisville

Indianapolis

Knoxville

Cincinnatti

Washington

Jacksonville

Birmingham

Nashville

Momphis
Function

Trunk

Trunk

Trunk

Connector

Trunk

Trunk

Connector

Trunk

Trunk

Connector

Connect or

Trunk

Connector

Connector

Connector

Trunk.

Trunk

Trunk

Trunk

Trunk (many carriers)

Trunk (many carriers)

Trunk (many carriers)

Trunk

Connector

Connector

Trunk

Trunk

Trunk

Trunk

Trunk

Connector

Trunk

Trunk

Trunk

Trunk

Trunk

Trunk

Trunk

Trunk

Trunk

Trunk

Trunk

Connector

Trunk

Trunk

Trunk

Trunk

Connector

Trunk

Trunk

Connector

Connector

Connector

Connector

Connector 
In general, the designation of connecting lines versus major trunklines was based on whether or nnt the rata showed that the line carried more than 20 million gross tons per mile (designated a trunkline) or between 10 and 20 million gross tons per mile per year (designated a connector).

Each of the corridors identified in the figure has one or more railroads carrying the traffic. By inspection of transportation zone maps and based upon previous experience, we identified 22 Class I rail railroads as responsible for the majority of the services provided. The carriers included in the main line network are listed in Table $\mathrm{A}-2$.

\section{Table A-2}

CARRIERS WITH ROUTES INCLUDED IN CORRIDOR DESCRIPTION

\begin{tabular}{|c|c|c|}
\hline ATSF & & Atchison, Topcka and Santa Fe \\
\hline $\mathrm{B} \& 0$ & & Baltimore and Ohio \\
\hline $\mathrm{BN}$ & & Rurlington Northern \\
\hline $\mathrm{C} \& 0$ & & Chesapeake and Ohio \\
\hline CMSP & & Chicago, Milwaukee, St. Paul and Pacific \\
\hline CRIP & & Chicago, Rock Island and Pacific \\
\hline DRG & & Denver and Rio Grande Western \\
\hline EL & & Érie Lackawanna (Now ConRail) \\
\hline ICG & & Illinois Central onlf \\
\hline LN & & Louisville and Nashvill,e \\
\hline $\mathrm{LV}$ & & Lehigh Valley (Now ConRail) \\
\hline MP & & Missouri Faclfle (1ncluding l'cxas Pacific) \\
\hline NW & & Norfolk and Western \\
\hline PC & & Penn Central (Now ConRail) \\
\hline RDG & $\dot{\gamma}$ & Reading (Now ConRail) \\
\hline SCL & & Seaboard Cnast Line \\
\hline $\operatorname{SLSF}$ & & St. Louis-San Francisco \\
\hline SSW & & St. Inuis-Southwestern. \\
\hline SOU & & Southern \\
\hline SP & & Southern Pacific \\
\hline UP & & Union Pacific \\
\hline WP & & Western Pacific \\
\hline
\end{tabular}


After we determined that a route should be included, we coded incatinns along the routes (node identifiers). The criteria for node selection were as follows:

- Junctions or end points for routes within a company

- Points where dramatic changes in altitude occur

Altitude of each node was obtained primarily from Reference 34. The altitudes of intermediate locations in some cases was estimated from contour maps if the slope-showed dramatic change and no other altitude data were available. Lastly, each section of track between nodes (1inks). was described in terms of distance and density class. Distance information was obtained from "Handy Railroad Atlas of the United States" Rand McNally, 1973 (Ref. 35). The density classes were coded using "United States Transportation Zone Maps," United States Department of Transportation, February 4, 1974.

The corridor description provides a network of about 600 nodes and approximately 1,200 links. The resulting network is shown in Figure 5 in Section III of this report.

Routes within the corridor for each company were chosen to show the flow of traffic in the most realistic way. This definition of routes leads to a total of approximately 110 bidirectional routes in the network.

The nodes, links, and route descriptions have been coded for computer processing. Summary statistics for both the physical and operational elements of the network are described later. The next section contains a description of the operationally related inputs to the models.

\section{Operational Characteristics}

Given a description of the physical network to be modeled, the nperations of the particular company over that route must be estimated. This includes estimates of train schedules, train size, numbers of empty and loaded cars, size of the load, and number of locomotives required. The remainder of this section gives details of the inputs chosen for use in the economic and fuel models.

The model, as presently used, is simplified by the concept of an average train. Schedules and resulting velocity information for a single average train for each direction on a route have been estimated frnm Reference 36. For some companies, this information was supplemented by operating schedules and track speed limit information. The number of these average trains (in one year) is calculated using the statistics on average train length reported to the Interstate Commerce Commission. The number of trains is calculated as the number required to move the annual traffic at a set number of cars per average train. 
Annual traffic is calculated from gross ton-mile density class information found in the Zone Maps (Ref. 16). This source provides seven ranges of gross ton-miles of traffic per mile of track for the entire United States. The ranges, in millions of gross ton-miles per mile, are as follows:

$$
\begin{gathered}
0-0.9 \\
1-4.9 \\
5-9.9 \\
10-19.9 \\
20-29.9 \\
30-39.9 \\
40-\text { greater }
\end{gathered}
$$

All density class information is for two-way traffic. The net tons (cotal annual load) is calculated as the percentage of the midpoint of the density range on the link in the direction of travel. For example, suppose the estimated rate of net to gross tons for the road is $40 \%$. Also assume the traffic is found to be balanced at $40 \%$ heared east and $60 \%$ headed west. Finally, assume the density range on a particular link is 10 to 19.9 million two-way gross-tons annually. Then the net ton in west direction is calculated to be

$$
0.4 \times 0.6 \times 15 \times 10^{6}=3.6 \times 10^{6}=3.6 \times 10^{6} \text { net-tons }
$$

The number of loaded cars is estlmated from the average net tons per carload available in Moody's (Ref. 37). Empty cars are calculated to balance the loaded car flows. For example, if 200 cars per year move east, then 200 empties are assumed to travel in the westerly direction on the link.

Locomotive requirements are calculated based upon the trailing gross-tons on the heaviest link on the route. Required inputs are horsepower per locomotive and horsepower per trailing gross tons for the company. In most cases these figures range from 2,500 to $3,1.00 \mathrm{hp}$ per locomotive and $1.5 \mathrm{hp}$ per trailing gross ton.

These inputs have been coded and a computer program has been written which performs the calculation of overall operating characteristics as output. The summary outputs, as well as output from the fuel model, are lescribed in the next section.

\section{Summary Statistics}

Certain overall statistics by company and for the entire main line network are available. These summaries are useful for verification and 
as a check when the network is used as a data base for the fuel and cost models. The overall statistics by company and in total are shown in Table IV-3, which appears at the end of Appendix A. The remainder of this appendix contains an explanation of the meaning of the items in the table.

Routes in the printout shown are pairs of one-directional routes. Routes 1 and 2 for example, are a pair moving in opposite directions. "Route miles" is the distance along the route while "train-miles" is the number of miles times the number of average trains to use the route. The "net-ton-miles" is the total tons of load moved by the average train times the miles the load was moved along the route. "Gross-ton-miles" is the same figure for the total tonnage of load and equipment. Fuel is the amount of fuel estimated for the route by the energy model (see Appendix B). The last three figures, as the table indicates, are in millions.

Average train statistics are summarized next. "Power" is the number of locomotives for the heaviest portion of the route. This number of locomotives is assumed to be required over the whole to move the train over that heaviest link. "Empties" and "loads" are the number of cars in'the average train. The "net-tons" figure is the average load over the route. This figure, when multiplied by train miles for the train, will not generally match the net-ton miles for the route. "Net tons" is the actual sum of tons carried times miles carried, while the train load (net tons) is the average load over all links on the route. "Number" is the number of this type of average train.

"Company totals" in the table provide the same information described above for routes as well as road-miles (total miles of track) and car and locomotive unit-miles for the company. The last page shows the totals for the 22 companies. 
Table A-3

SUMMARY OF CORRIDOR NETWORK DESCRIPTION
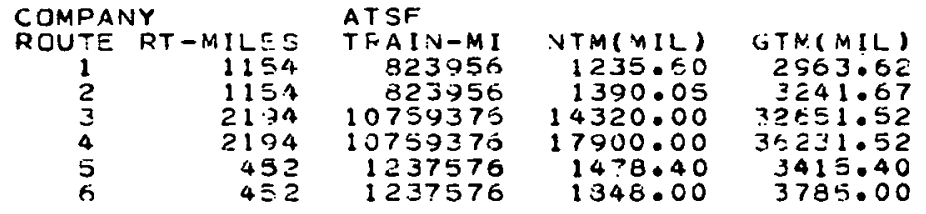
FUEL (MIL)
(MIL)
2.63
4.69 45.43 57.06
3.83
$5 \cdot 53$

AVERAGE TRAINS
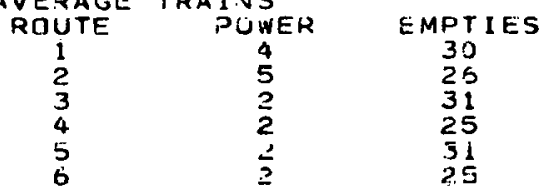
LUADS

ADS
28
30
25
31
25
31

N.ET TONS

1404

1620

1350

1674

1350

NUMGER

714

714
4904

4904

4904

2730

COMPANY TUTALS

RT - MILES
7500
ROAD-MI
TFAIN-MI NTM(MIL) 25641815 32172.05 CAR-MI (MIL) LOC-MI GIN(NIL) FLEL(MIL)
B2288.72

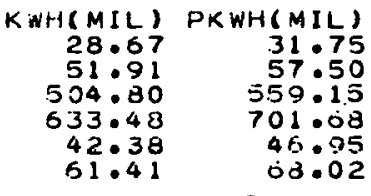

PERCENT TRAFFIC

1.00

1.00

1.00

1.00

1.00

KWH(MIL) PKWH(MIL) $1322.55 \quad 1465.05$

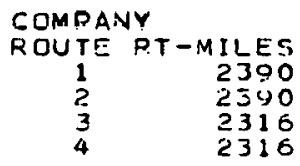

HN
THAIN-MI
6651370
6651370
4539360
4539360

NTM(MIL)
13204.95
10904.05
8967.10
7290.70

GTN(NIL) FUFL (MIL)

20243.59

25844.98

21122.00

61.06

5.3 .49
20.41

KWH (MIL) HKWH(MIL) 680.68 753.9? $598.46 \quad 662.90$ $\begin{array}{ll}588.46 & 362.90 \\ 286.79 & 317.67\end{array}$ $18254.70 \quad 2.3 .49$

257.99

285.75
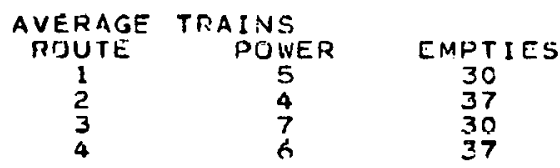

LUADS
37
30
37
30

NET TONS
2035
1650
2035
1650

NUMEER 2783 1960

PERCENT TRAFFIC 1.00

1.00

1.00

COMPANY TOTALS

P.T-MILES

Y4I2 TRAIN-MI NTM(MIL) RIAT-MI

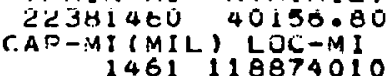

GTM(NIL) FUEL (MIL)
95005.27

KWH(MIL) PKWH(MIL) IU2J.92 2020.30 1461118874010 
Table A-3 (Continued)
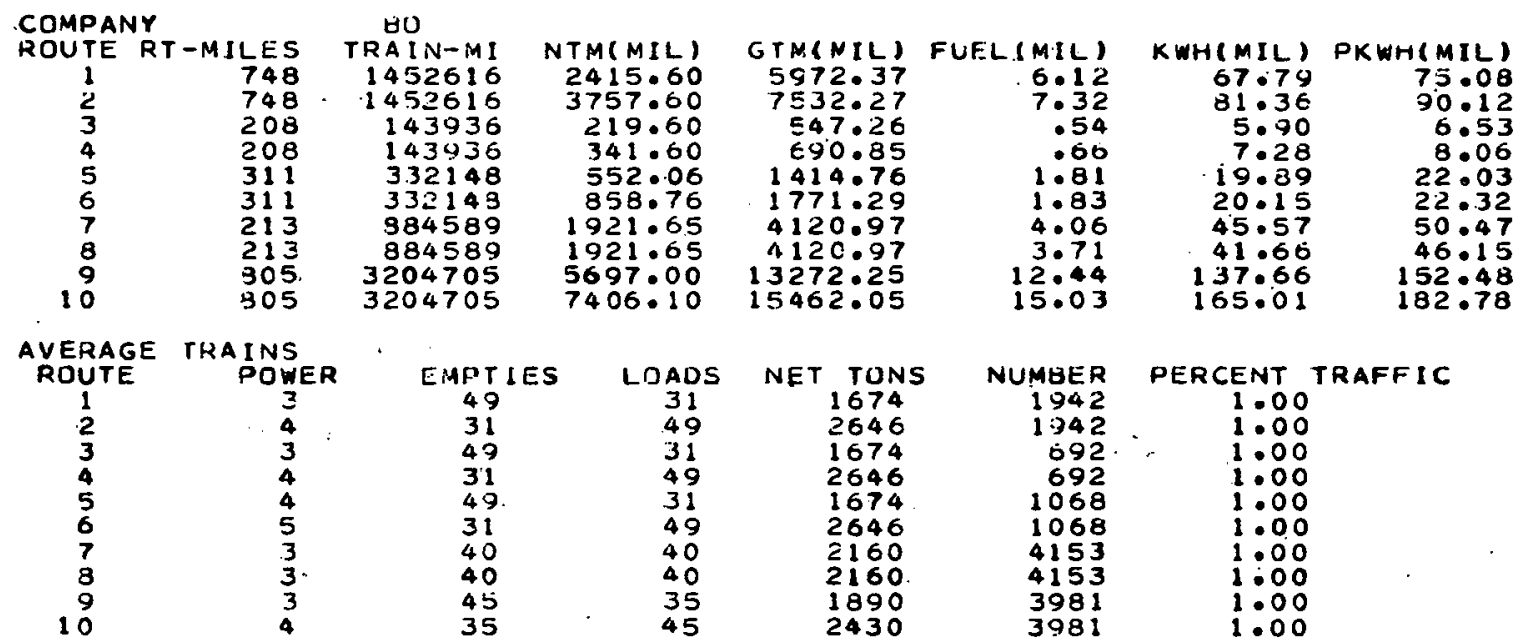

LDADS
31
49
31
49
31
49
40
40
35
45

NET TONS

NUMBER PERCENT TRAFFIC 1674
2646
1674
2646
1674
2646
2160
2160
1890
2430 $M G R$
1942
1942
692
692
1068
1068
4153
4153
3981
3981

COMPANY TOTALS

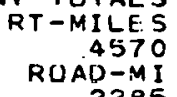

TRAIN-MI NTM(MIL) 1203598825091.62 2285

$$
929^{41905665}
$$

GTMIMIL) FUEL (MIL) S月905.05 53.50

KWH(MIL) PKWH(MIL)

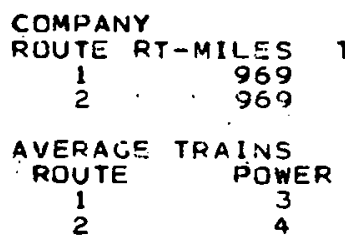

$$
C 0
$$

TRAIN-MI NT.M(MIL) 4658952 .

7146.70 GTM(MIL)

FUEL (MIL)

7146.70
$10720.05 \cdot 17550.04$
22222.23

15.86
19.39

KWH(MIL) PKWH\&MIL) $176.43 \quad 195.42$ $21.7 .21 \quad 240.59$

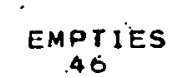
LOADS $A D S$
31
46

NET TONS

NUMBER
4808
4808 31

TRAIN-MI NTMIMIL

$9317904,17866.75$

GTM(MIL) FUEL(MIL) 40172.26

35.25 68732612664
PERCENT TRAFFIC 1.00 1.00

KWH(MIL) PKWH(MIL) 


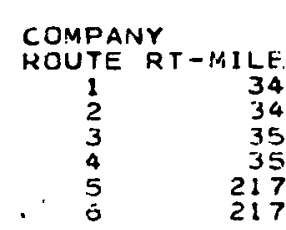

AVFRAGE TRAINS

ROUTE POWER

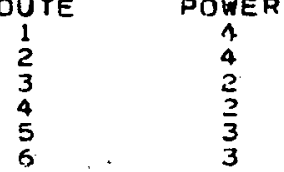

$C M P$

TFAIN-MI NTM(MIL)

621762

जट1762

743631

743631

3569175

$1006 \cdot 25$

1006.25

933.97

111.87

5085.00

4271.40

3569175

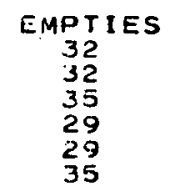

GTM(MIL) FUEL (MIL) 2495.51 2287.35 2465.25 $1,808.31$ $1: 084.71$

COMPANY TOTALS

$$
\text { RT M ILES }
$$$$
\text { ROAD-MI }
$$$$
2876
$$

TRAIN-MI NTM(MIL) $9369136 \quad 13414.75$ CAR-MI (HIL) LOC-MI
LOADS

32
32
29
35
35
29

\section{NET TONS}$$
1472
$$$$
1472
$$

1334

1610

1610

1334 $\begin{array}{rr}\text { GTN(MIL) } & \text { FUEL(MIL) } \\ 32726.65 & 33.08\end{array}$ $586 \quad 29363670$

NUMBER

1797 1797 2083 2083 1641

1641

$$
\begin{array}{r}
2.61 \\
1.62 \\
2.91 \\
3.67 \\
10.83 \\
11.44
\end{array}
$$

$\begin{array}{rr}\text { KWH(MIL) PKWH(MIL) } \\ 369.31 & 409.07\end{array}$

KWH(MIL) NKWH(MIL)

$\begin{array}{rr}29.29 & 32.45 \\ 18.22 & 20.13 \\ 32.69 & 36.21 \\ 41.19 & 45.63 \\ 120.74 & 133.74 \\ 127.17 & 140.85\end{array}$

PERCENT TRAFFIC 1.00 1.00 1.00 1.00 1.00 1.00
COMPANY

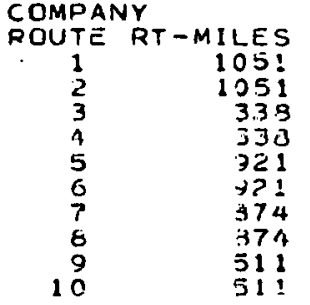

CRIP

TRA IN-MI 928033 928033 50024 50024 837189 e371:39 137364 337364 106283 100288
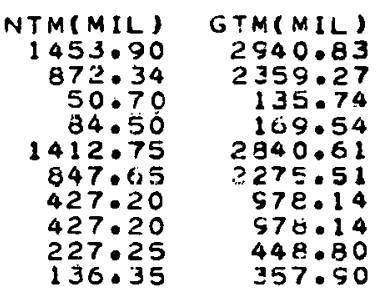

(MIL) 3.06 .13 .17 1.68 3.08 .70

1.20

.33

AVERAGE TRAINS

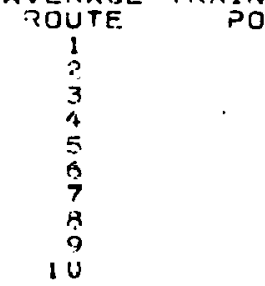

ONER

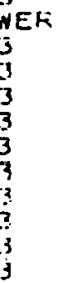

EMPTIES

LCADS

NET TONS

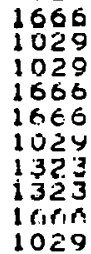

NUMBER

8.93
14

1413

909

909

386

386

204

21

COMPANY TUTALS

$$
\begin{array}{r}
\text { RT - I I L :S } \\
7390 \\
\text { ROA- in } \\
35 \div 5
\end{array}
$$

THAI:N-MI NTM(MIL) 4517790 , S939.94 CAF-MI $(M[1), L J C-M 1$
GT MI IIL) FUEL (MIL) 13494.46 I3.15
KWH(MIL) PKWH(MIL)

$\begin{array}{rr}25.95 & 28.75 \\ 33.99 & 37.65 \\ 1.45 & 1.61 \\ 1.89 & 2.09 \\ 18.89 & 20.93 \\ 34.82 & 39.35 \\ 7.83 & 8.67 \\ 13.51 & 14.96 \\ 3.73 & 4.14 \\ 4.86 & 5.39\end{array}$

PERCENT TRAFFIC

$$
1.00
$$

1.00

1.00

1.00

1.00

1.00

1.00

1.00

KWH(MIL) PKWH(MIL)

$140.73 \quad 16 ? .53$ 
Table A-3 (Continued)

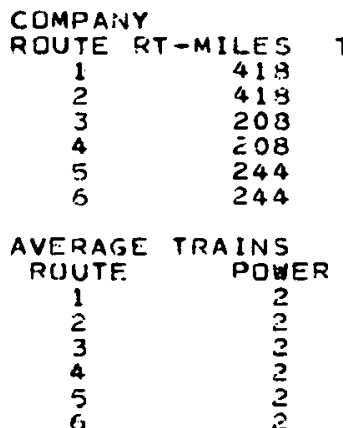

COMPANY TOTALS

$$
\begin{array}{rcc}
\text { RT-MILES } & \text { TRAIN-MI } & \text { NTM(MIL) } \\
1740 & 4971200 & 9360.50 \\
\text { RUAD-MI } & \text { CAR-MIIMIL) } & \text { LOC-MI } \\
870 & 299 & 9942400
\end{array}
$$

OHG

RAI N-MI NTM(MIL)

$483064 \quad 2329.90$

$433064 \quad 3241.60$

$461344 \quad 993.40$

$\begin{array}{ll}541192 & 841.80 \\ 541192 & 1171.20\end{array}$

EIAPTIES

35
25
35
25
35
35

LUADS

25
35
25
35
25
35

$$
\begin{aligned}
& \text { STN(MIL) } \\
& 5042.52 \\
& 5954.22 \\
& 1559.55 \\
& 1840.35 \\
& 1829.49 \\
& 2150.88
\end{aligned}
$$

FUELL

(MIL)

9.1 32

2.52

3.11

3.11

3.073

NET TONS

1550
2170

1550

1250

1550

2170

NUMBER
3548

3548

3548

2218

2218

2218

GTN(MIL) FUEL(MIL)

18365.00 अ 31.72 .
COMPANY

ROUTE RT-MILES

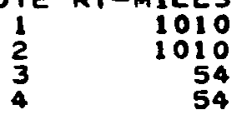

AVERAGE TRAINS

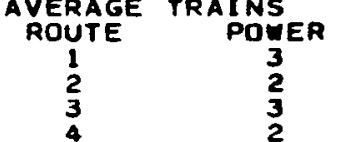

3
3
2
3
2

COMPANY TOTALS

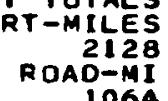

TRAIN-MI NTM(MIL)

$68 B 4472 \quad 9819.00$ CAR-MI (MIL) LOC-MI
GTM(MIL) FUEL (MIL)
12534.93 IT.35

$0428 \cdot 14$
267.58

$267 \cdot 58$

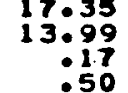

NET TONS

$$
\begin{array}{r}
\text { TON } \\
1620 \\
1125 \\
1620
\end{array}
$$$$
1125
$$

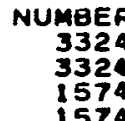

3324

3328

1574 GTM(MIL) FUEL (MIL)
23452.17 43517211180

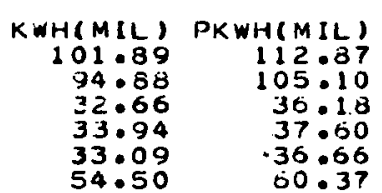

PERCENT TRAFFIC

1.00

1.00

1.00

1.00

1.00

KWHIMIL) PKWH(MIL) $350.97 \quad 388.76$

KWH(MIL) PKWH(MIL) 194.17 215.07 $156.80 \quad 173.68$ 1.78 5.78 $1 \cdot 97$
6.21

PERCENT TRAFFIC 1.00 1.00 1.00

KWH(MIL) PKWHCM:L $358.35 \quad 396.93$
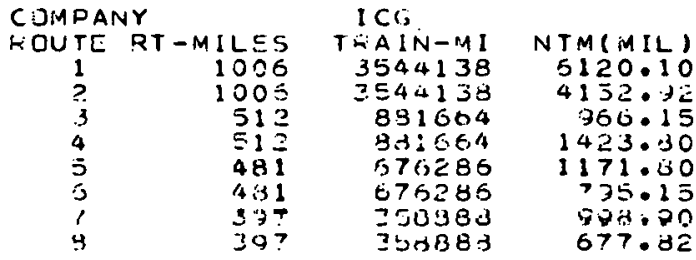

AVEUAFE TRAI:NS
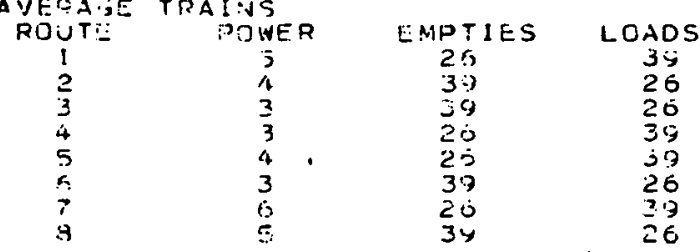

CUMWAINY TOTALS

$$
\begin{aligned}
& \text { FT - NIL } 479 \\
& \text { न () AD-N }
\end{aligned}
$$

(STM(MIL) FURL (MIL)

$14549.41 \quad 11.47$

$12 \mathrm{C} 50.61$

2705.54

3163.15

2690.14

2212.05

วิ่ 1.47

: 936.56

11.19

2.74

2.13

2.09

1.099

NET TUNS

$10 N 5$
1755
1170
$117 C$
1755
1755
1170
1755
1170

NUMBER

$35 ? 3$

3523

1722

$172 \frac{1}{1405}$

1405

1406

904

GTNINIL) FUSL (MIL)

35.82

(
KNH(MIL) PKWH(MIL) 400.0

443.12

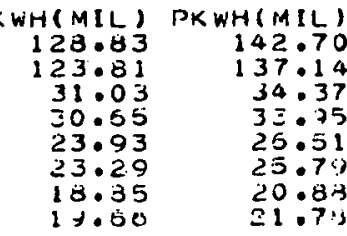

NERCENT THAFFIC $1.0 \mathrm{C}$ 1.00 1.00 1.00 1.00 1.00 1.00 
Table A-3 (Continued)
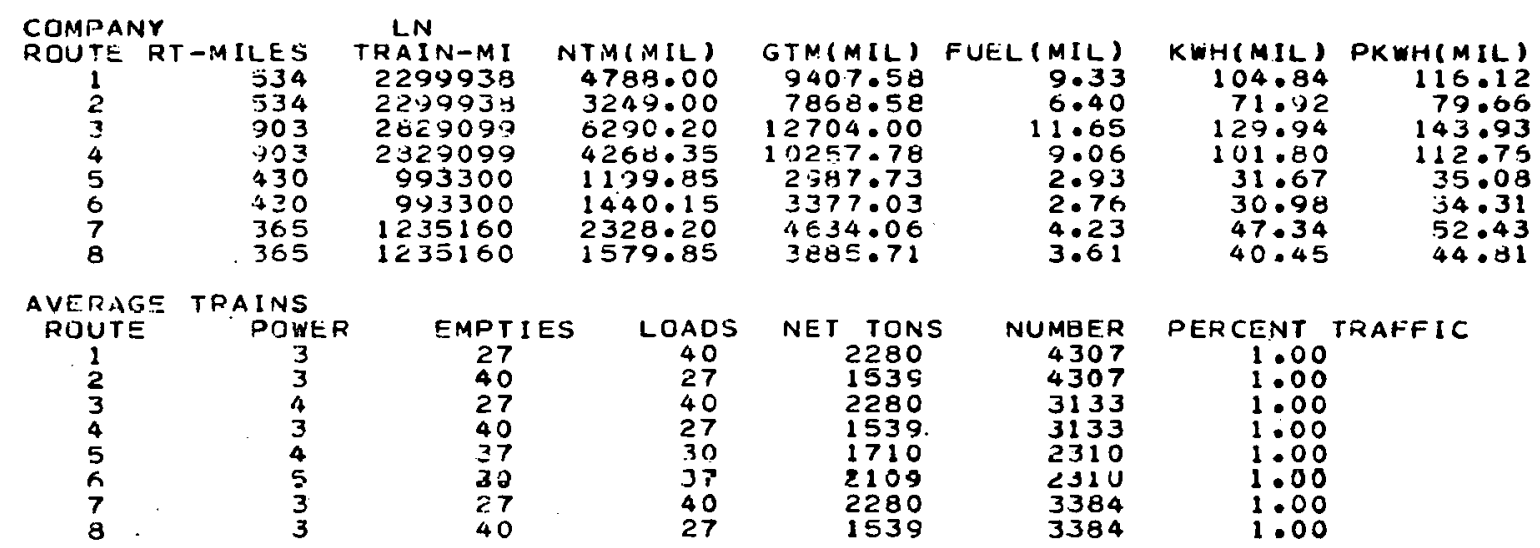

NET TONS

$$
\begin{aligned}
& 2280 \\
& 1539 \\
& 2280 \\
& 1539 \\
& 1710 \\
& 2109 \\
& 2280 \\
& 1539
\end{aligned}
$$

NUMBER

4307
4307

3133

3133

2310

2310

3384

PERCENT TRAFFIC

1.00

1.00

1.00

$1: 00$

1.00

1.00

3384
Comphar rotales

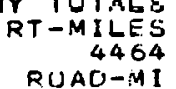
TRAIN-MI NTM(MIL)
I47I4994, 25143.60
CAR-MI MIL N LOC-MI
BBS

GTM(MIL) FUEL (MIL)
55122.47

KWH(MIL) PKWH(MIL) 2232

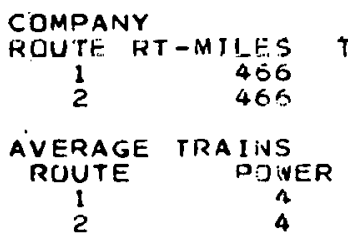

LV
TEAIN-MI

1099760 NTM(MIL)

$\begin{array}{ll}1099760 & 1453.72 \\ 1099760 & 2145.97\end{array}$

$\begin{array}{rr}\text { GTM(MIL) FUEL(NIL) } \\ 3968.19 \\ 1660.44 & 4.21 \\ 4.70\end{array}$

KWH(MIL) PKWH(MIL)
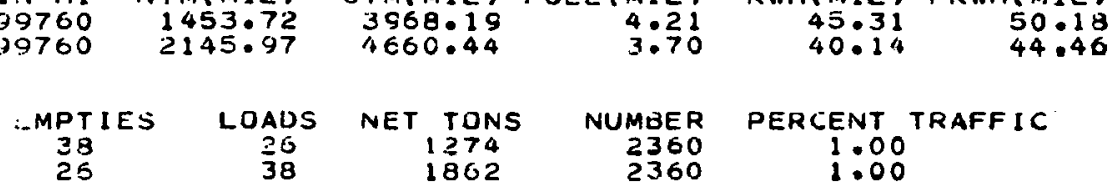

LOAUS

NET TONS

NUMBER 2360

PERCENT TRAFF IC 1.00

COMPANY TOTALS

GUAID-MI

TRAIN-MI NTMIMILI

PIQ95PR $350 \% .70$

CAR-MI (MIL) LOC-MI

GTM(MIL) FUEL (MIL)

8620.62

$T \cdot 91$

KWH(MIL) PKWH(NIL)

85.45. $\$ 4.64$


Table A-3 (Continued)
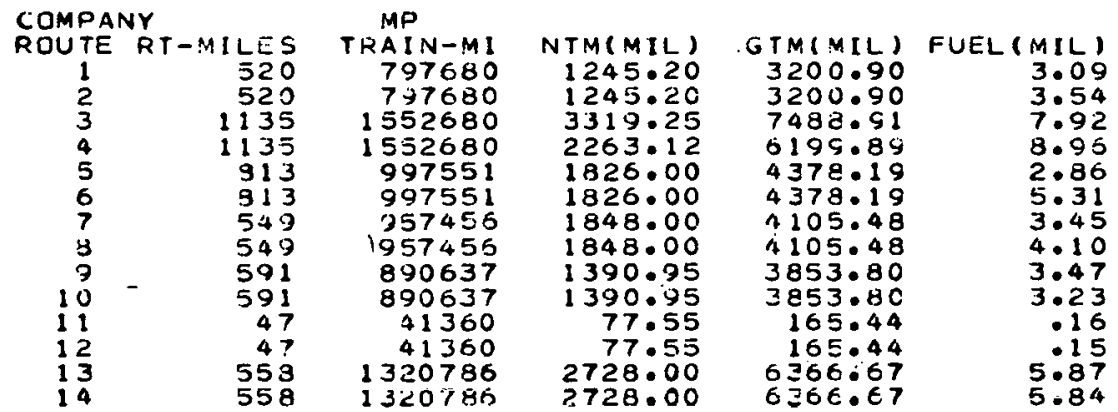

AVERAGE TRAINS
ROUTE POHER

1320786

2728.00

$6 \equiv 6 \epsilon \cdot \epsilon 7$

$5 \cdot 84$
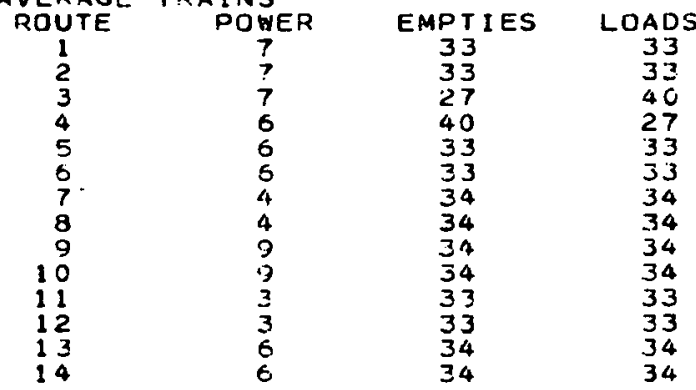

NET TONS

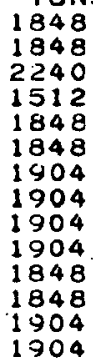

NUMBER

1534

1534

1368

1368

1227

1227

1744

1744
1744

1744
1507

1507

880

880

$2=67$

2367

COMPANY TOTALS

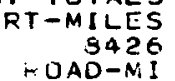

TRAIN-NI NTM(MIL)
131 NG300 23813.77 13115300
$C A R \rightarrow M I(M I L)$ 4213 84983111678

STN(MIL) FUEL (MIL) $57829.76 \quad 57.96$

COMPANY

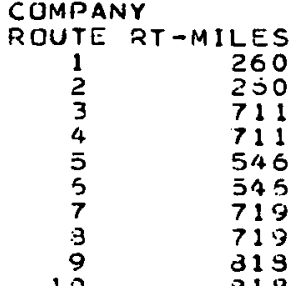

$N W$

TEA IN-MI 700780 740780 2543958 2543958 2356072 2836672 3320970 3320970

6991445

0701446

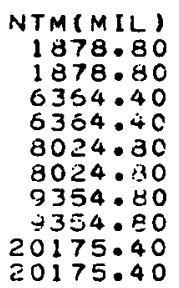

$$
\begin{array}{r}
\text { JTN(NIL) } \\
4014.53 \\
1 C 19.53 \\
13944.48 \\
13944.48 \\
13228.77 \\
1628.77 \\
18596.66 \\
19596.60 \\
38889.48 \\
313839.48
\end{array}
$$

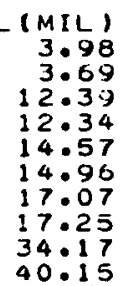

(MIL)
3.98
3.69
12.39
12.34
14.57
14.96
17.07
17.25
34.17
40.15

NUMEER

3003

3003

3578

3578

5232

5232

4630

4030

4030

8547
8547 KWH(MIL) PKWH(MIL)
645.1 I

714.57

KWHIMIL) PKWHIMIL)

$\begin{array}{rr}34.77 & 38.52 \\ 39.50 & 43.75 \\ 85.87 & 95.12 \\ 00.07 & 110.84 \\ 30.77 & 34.08 \\ 59.71 & 00.14 \\ 38.74 & 42.91 \\ 46.07 & 51.03 \\ 38.95 & 43.14 \\ 36.28 & 40.19 \\ 1.81 & 2.00 \\ 1.66 & 1.84 \\ 65.24 & 72.26 \\ 65.67 & 72.74\end{array}$

PERCENT TRAFFIC 1.00 1.00 1.00

1.00

1.00

1.00

1.00

1.00

1.00

1.00

1.00

645.11
KWHIMIL) PKWHIMIL)

$\begin{array}{rr}49.68 & 49.49 \\ 41.41 & 45.87 \\ 1.39 .23 & 154.22 \\ 138.09 & 153.62 \\ 163.70 & 231.33 \\ 158.05 & 135.15 \\ 171.82 & 212.47 \\ 193.84 & 2.4 .71 \\ 381.91 & 423.03 \\ 447.06 & 495.19\end{array}$

PERCENT TRAFF IC

1.00

1.00

1.00

1.00

1.00

1.00

1.00

1.00

COMPANY TUTALS

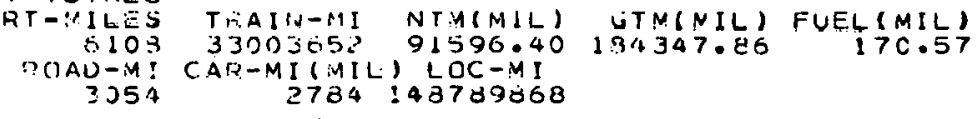

UTN(NIL) FUEL (MIL) 134347.86 3254 $2784: 48789068$

KWH(MIL) PKWH(MLL) 1910.39 रा16.0\% 
Table A-3 (Continued)

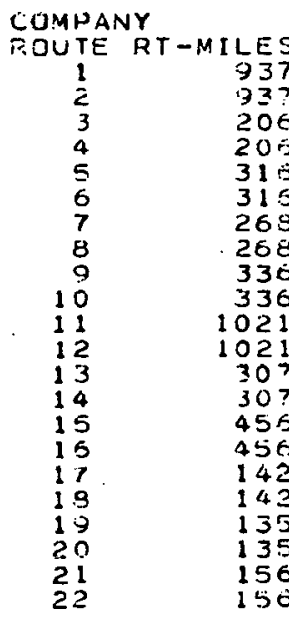

$\operatorname{HC}$
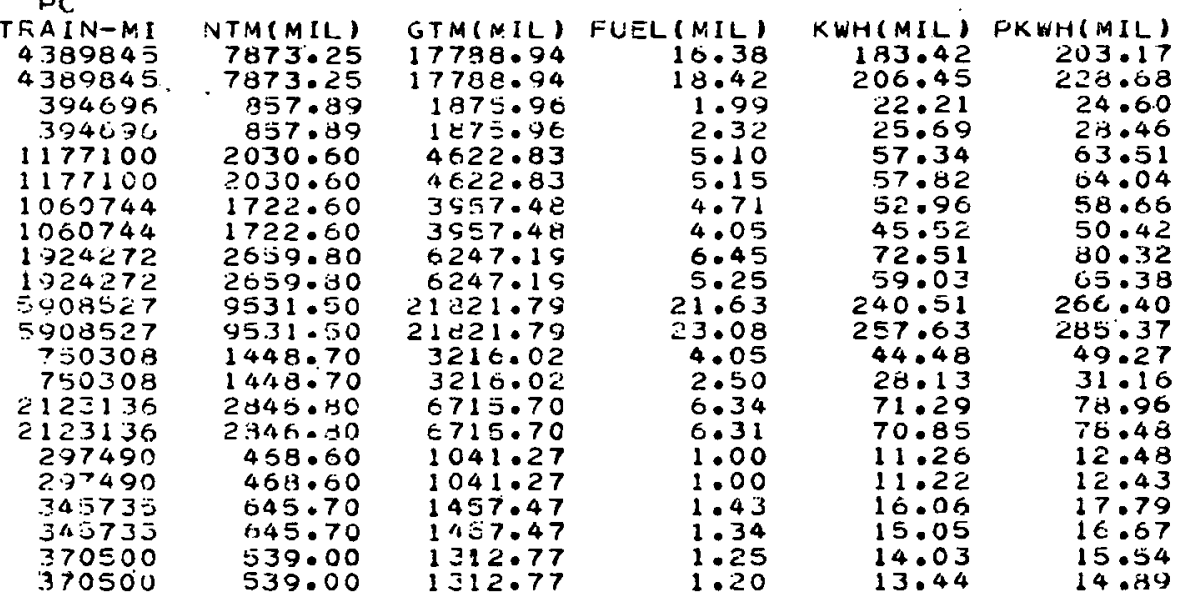

AVERAGE TRAIN:T

$\begin{array}{ccc}\text { ROUTE } & \text { POWER } & \text { EMPTIES } \\ 1 & 3 & 321 \\ 2 & 3 & 32 \\ 3 & 2 & 31 \\ 4 & 7 & 31 \\ 5 & 3 & 31 \\ 6 & 3 & 31 \\ 6 & 3 & 31 \\ 7 & 3 & 31 \\ 8 & 3 & 31 \\ 9 & 3 & 31 \\ 10 & 3 & 31 \\ 11 & 31 & 31 \\ 12 & 4 & 32 \\ 13 & 4 & 32 \\ 14 & 3 & 32 \\ 15 & 3 & 32 \\ 15 & 32 \\ 17 & 2 & 32 \\ 13 & 2 & 31 \\ 13 & 3 & 31 \\ 20 & 3 & 31 \\ 21 & 4 & 31\end{array}$

LOAOS

NET TONS

NUMBER 4685 4685
4685 4685
1916 1916 3725 3725 3958 3958 5727 5727 5787 5787 578 2444 4056 4655 2035 2095 2561 2501 2501

PEP.CENT TRAFFIC 1.00 1.00 1.00

1.00

1.00

1.00

1.00

1.00

1.00

1.00

1.00

1.00

1.00

1550

1600

1600

1550

1530

2375

CUMHANY TUTALS

$$
\text { RT - MIL }
$$

TRAIN-MI NTMIMIL

GTN(MIL) FUEL (MIL) LAF-MI (MIL) LUC-MI

140.95

KWH(MIL) PKWH(MIL) 1576.9

1746.10

\footnotetext{
$2445 \div 14890146$
} 
Table A-3 (Continued)
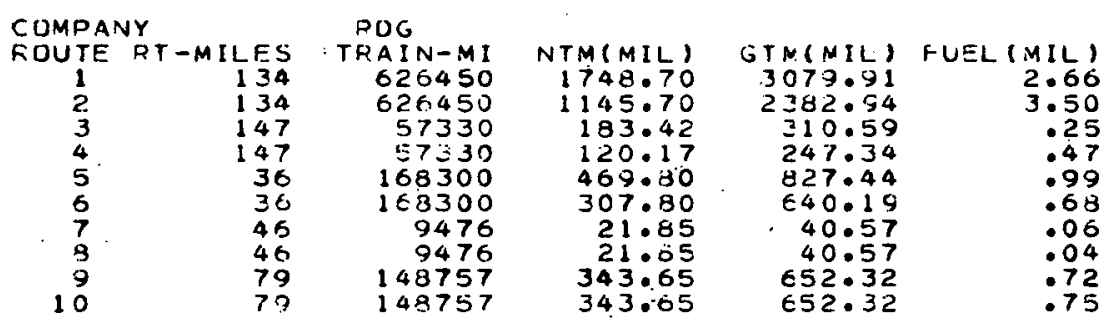

KWHIMIL) PKWH(MIL)

$\begin{array}{rr}(M I L) & \text { PKWH(MIL) } \\ 29.51 & 32.63 \\ 39.30 & 43.53 \\ 2.64 & 2.93 \\ 5.21 & 5.77 \\ 11.10 & 12.30 \\ 7.64 .68 & 3.46 \\ .68 & .75 \\ .50 & .56 \\ 8.13 & 9.00 \\ 8.42 & 9.33\end{array}$

\section{AVERAGE TRAINS}

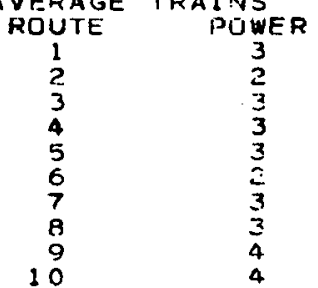

EMPTIES

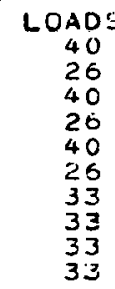

NET TONS

26
40
20
40
26
40
33
33
33
33

$A 0 S$
40
26
40
20
40
26
33
33
33
33

COMPANY TOTALS

$$
\begin{array}{r}
\text { RT - MILES } \\
884 \\
\text { ROAD-MI } \\
442
\end{array}
$$

TRAIN-MI NTM(MIL) $2020626 \quad 4706.60$ $\begin{array}{ll}C A R-M I(M I L) & L Q C-M I \\ 134 & 5564642\end{array}$

GTM(NIL') FUEL(MIL)
E874.19

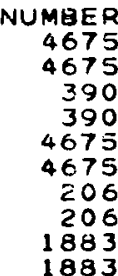

PERCENT TRAFFIC 1.00 2800

2800

1820

2800

1820

2310

2310

2310

2310

1883

1.00

1.00

1.00

1.00

1.00

1.00

1.00

1.00

KWH(MIL) PKWH(MIL)
113.12 125.30
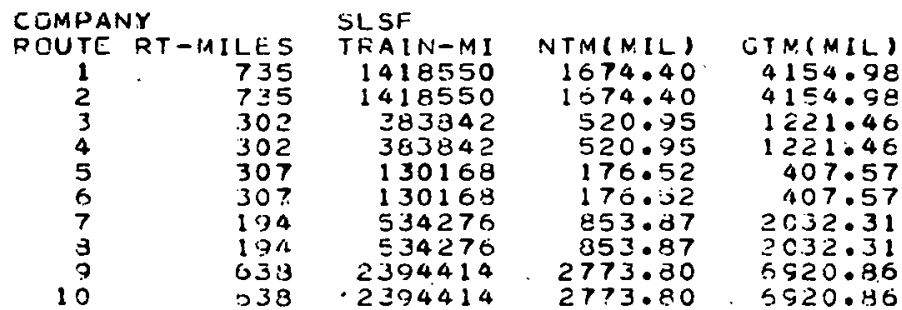

FUFL(MIL)

(MIL) 4.62 $1 \cdot 15$

1. 11

. 37

.42

1.75

1.75
2.14

$2 \cdot 14$

5920.46

6.56

AVERAGE TFAINS
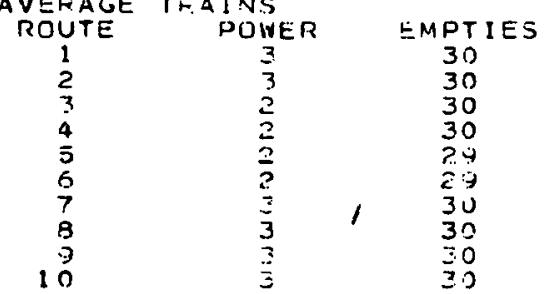

LOADS
30
30
30
30
29
29
30
30
30
30

NET TONS

1330
1380
-1380
1380
1334
1334
1380
1330
1380
1380

NUMBER 1930

1930

1271

1271

424

424

2754

2754

3753

KWH(MIL) NKWH(MIL)

$\begin{array}{rr}38.59 & 42.74 \\ 51.86 & 57.44 \\ 12.90 & 14.29 \\ 12.42 & 13.76 \\ 4.17 & 4.62 \\ 4.67 & 5.18 \\ 19.09 & 21.01 \\ 24.02 & 28.61 \\ 73.79 & 81.73 \\ 73.05 & 81.53\end{array}$

COMPANY TUTALS

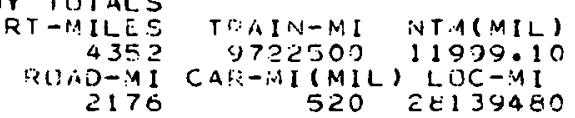

GTN (N.IL)

23474.38 FUEL (MIL)
$2 B .11$

KWH(MIL) OKWH(
315.70

PERCENT TRAFFIC

1.00

1.00

1.00

1.00

1.00

1.00

1.00

1.00 
Table A-3 (Continued)
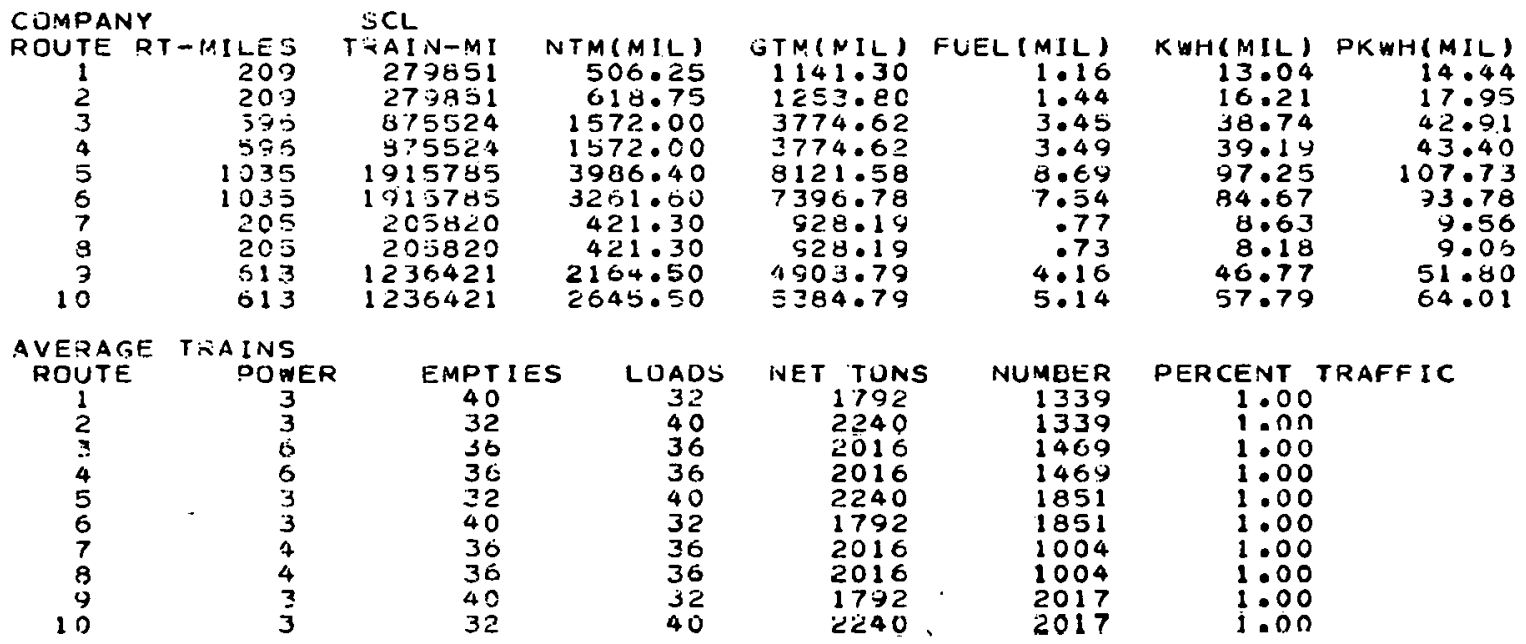

INET TUNS 1792

2240

2016

2016

1792

2016

2016

2016

1792
2240

NUMBER

1339

1339

1469

1469

1851

1004

1004

1004

2017

COMPANY TOTALS

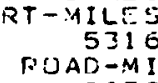

TFAIN-MI NTM(MIL) 902600217169.60

CAR-MI(MIL) LUC-MI
012
32745190

GTM(MIL) FUEL (MIL)
ZTEOT.67

PERCENT TRAFFIC

1.00

$1.0 n$

1.00
1.00

1.00

1.00

1.00

1.00

2659

KWH(MIL) PKWH(MIL)

410.45

454.64

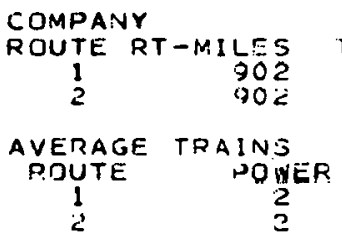

$$
\begin{aligned}
& \text { TS N } \\
& \text { TF:A IN-MI }
\end{aligned}
$$

NTM(MIL)

8088.00
8088.00

$\begin{array}{rr}\text { GTMIMIL) } & \text { FUEL (MIL) } \\ 1 \text { ISI7.65 } & 20.41 \\ \text { IES17.65 } & 21.51\end{array}$

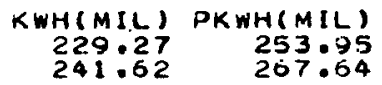

401570.4 253.95

pencent tratric 1.00

COMPANY TOTAL

$$
\begin{aligned}
& \text { hI-MILES } \\
& \begin{array}{r}
\text { PUA })-M \\
40 ?
\end{array}
\end{aligned}
$$
EMPTIES

$$
33
$$

38 5052
20502

NUMHEA

4452

1.00

$$
\begin{gathered}
\text { TPAINAMI NTM(MIL) } \\
\text { ANIIAOA ISIT6.OOO } \\
\text { CAF-MI(MIL) LOC-MI }
\end{gathered}
$$

GTM(MIL) FIJFL (MIL)

$3,3835.30$

42.91

K.HH(MIL) PKWHCMIL) B42 16062816 

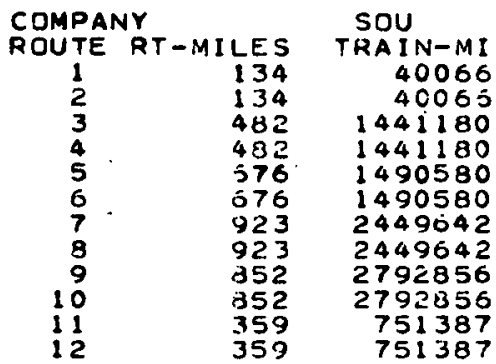
90.45

3042.90

2028.60

2412.45

2412.45
3618.67

3335.40

5003.10

4231.80

6347.70

1160.10

1740.15

\begin{abstract}
AVERAGE TRAINS
\end{abstract}

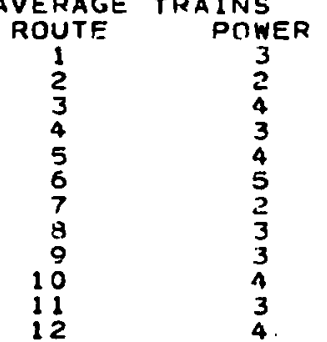

EMPT IES

LOADS
40
26
40
26
26
40
26
40
26
40
26
40

26
40
26
40
40
26
40
26
40
26
40
26

COMPANY TUTALS

RT - MILES

RUAD-MI

3426

116260761721
NTM(MIL)
GTM(MIL) FUEL(MIL)

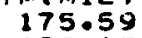

139.43

$61 \in 9.99$

4939.51

7412.10

9848.38

10188.09

12722.92

2739.13

3431.89

NET TONS

2280
1482
2280
1482
1482
2280
1482
2280
1482
2280
1482
2280

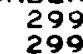

299
2990

2990

2205

2205

2654

2654

3278

3278

2093

2280

GTM(MIL) FUEL(MIL)

I7931422 33071.62
5982.29
SP

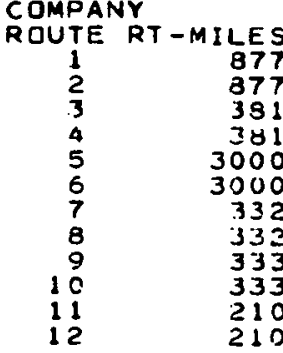

TRAIN-MI

3139660

557892

12252000

12252000

615196

615196

1134531

1134531

363720

NTM(MIL)

5270.85
8061.30

$8061 \cdot 30$

1485.90

20429.55

23844.65

846.50

1444.20

1779.05

535.50

319.00

GTM(MIL) FUEL (MIL)

13324.60

16115.05

2390.32

46047.05

51279.95

2169.27

$276 \in .87$

2957.61

3743.61

$1 \geq 17.50$

$1 \in 01.00$

19.09
17.78

2.96

2.63

54.02

58.77

2.79

2.69

3.78

3.51

1.61

AVERAGE TFAINS
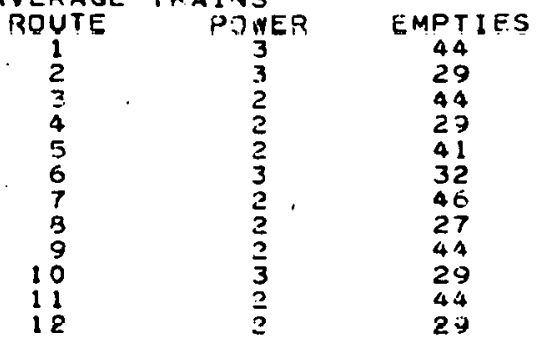

LAD
29
44
29
44
32
42
27
46
29
44
29
44
NUMGER

3580

3580

1732

4084

4094

1853

1353

3407

3407
3139660

$\begin{array}{lll}2479 & 1732 & 1.00 \\ 2244 & 1732 & 1.00\end{array}$

$\begin{array}{lll}1479 & 1732 & 1.00 \\ 2244 & 1732 & 1.00\end{array}$

KWHIMIL) PKWH(MIL)

$\begin{array}{rr}1.43 & 1.58 \\ 1.52 & 1.69 \\ 51.17 & 56.68 \\ 62.86 & 69.63 \\ 64.28 & 71.20 \\ 55.56 & 61.54 \\ 131.85 & 146.04 \\ 148.94 & 164.97 \\ 116.81 & 129.38 \\ 130.63 & 144.70 \\ 27.14 & 30.06 \\ 29.86 & 33.08\end{array}$

PERCENT TRAFFIC

1.00

1.00

1.00

1.00

1.00

1.00

1.00

1.00

1.00

1.00

1.00

KWH(MIL) PKUH(MIL) $822.05 \quad 910.55$

KWH(MIL) PKWHCMIL)

192.30

32.73

29.27

604.37

$604 \cdot 3$

$658 \cdot 47$
$31 \cdot 32$

30.21

$42 \cdot 43$

39.44

18.10

18.51

$$
\begin{array}{r}
233.05 \\
213.01 \\
35.25 \\
32.42 \\
669.38 \\
729.36 \\
34.69 \\
33.47 \\
47.00 \\
43.68 \\
20.05
\end{array}
$$

PERCENT TRAFFIC

1.00

1.00

1.00

1.00

1.00

1.00

1.00

1.00

1.00

1.00

$\begin{array}{lll}2479 & 1732 & 1.00 \\ 2244 & 1732 & 1.00\end{array}$

COMPANY TUTALS

$$
\begin{array}{r}
\text { F.T MAD MILET } \\
10256
\end{array}
$$

5133

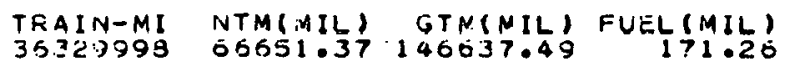
CAR-MI (MIL) LOC MI
KWH(MIL) PKWH(MIL) $1907.50 \quad 2112.8$ ? 


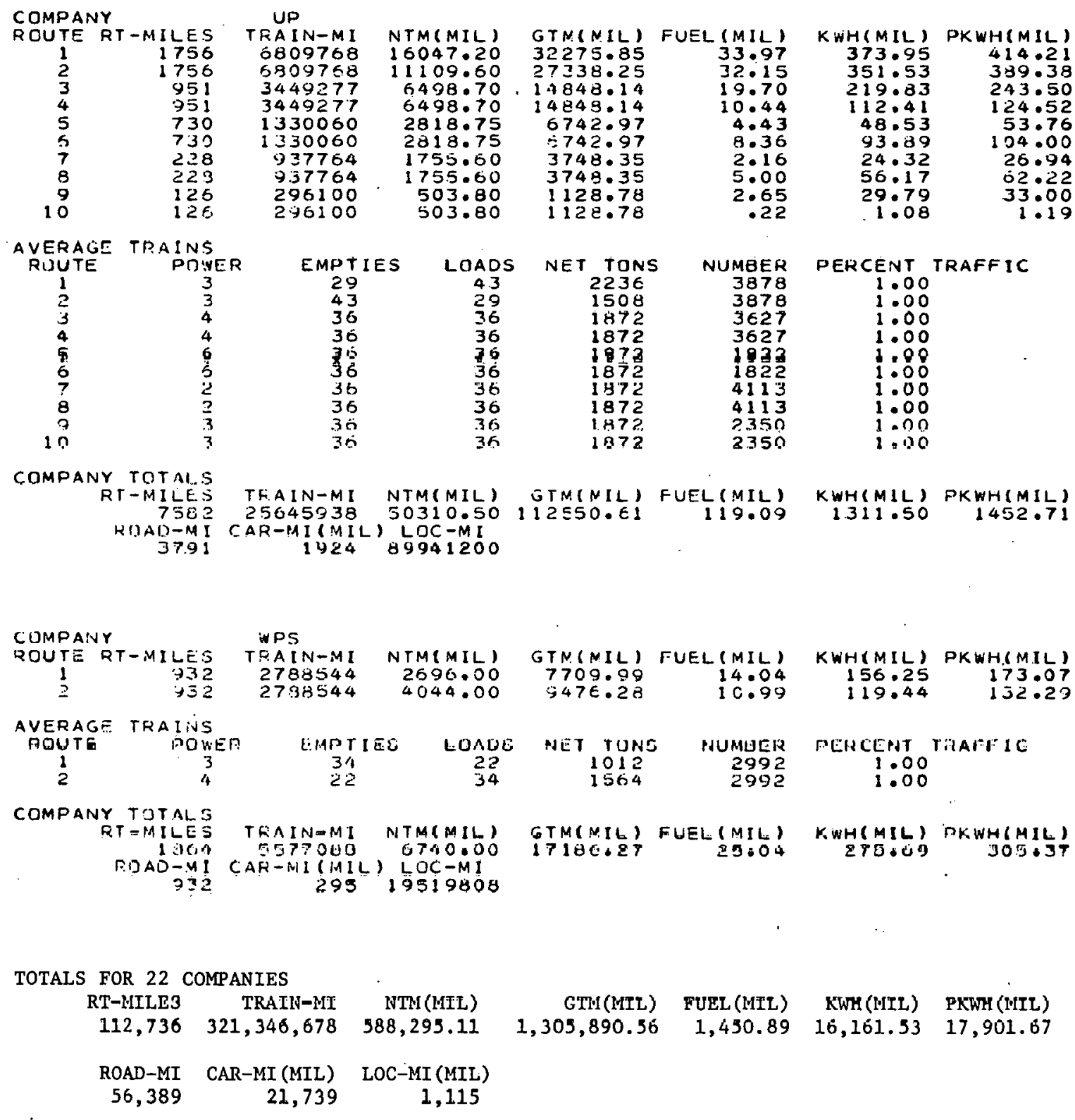


Appendix B

RAILROAD ENERGY USE AND FUEL CONVERSION 
THIS PAGE

WAS INTENTIONALLY

LEFT BLANK 
Appendix B

RAILROAD ENERGY USE' AND FUEL CONVERSION

Railroad vehicles consume energy moving over level ground, up grades, around curves, and in acceleration. The work done to move the train produces burning fuel in a locomotive prime mover or in a central station generating plant, where it is converted to electricity, and the electrical used energy to produce the work. The discussion will consider the resistance of the train to being moved, the conversion of that resistance into units of work, and the conversion of fuel into the work needed to move the train.

\section{Train Resistance}

The resistance of a train in motion consists of components related to movement on straight and level track, resistance due to grade, resistance due to curvature, and resistance to acceleration. Additional resistance due to static friction components is present in a standing train, but the energy requirement to overcome this static friction is small because of the short distances traveled before the static friction components disappear.

\section{Resistance on Straight and Level Rail at Constant Speed}

The resistance of the train on straight (tangent) and level rail arises from deflection of the track structure, wheels and rails; bearing friction in the car; sliding friction between the wheel flanges and rails; raising the car because of irregularities at joints in the rail; and aerodynamic resistance from motion of the train through the air. The equation for train resistance on straight and level rail can be expressed in the form:

$$
R_{1}=A_{i}+B_{i} W_{i}+C_{i} W_{i} S+D_{i} s+E_{i} s^{2}
$$

where $R_{1}$ is the resistance of the train on level track, in pounds; $A_{i}, B_{i}, C_{i}, D_{i}$, and $E_{i}$ are constants relating to the ith unit (1ocomotive, car, or caboose) in the train;

$W_{i}$ is the weight in tons of the ith unit in the train;

$S$ is the speed of the train in miles per hour.

Values for the constants are summarized in Ref. 38 as shown in Table B-1. 
Table B-1

CONSTANTS FOR VARIOUS TYPES OF TRAIN UNITS

Unit

\begin{tabular}{|c|c|c|c|c|c|}
\hline & $\mathrm{A}$ & $\mathrm{B}$ & $\mathrm{C}$ & $\mathrm{D}$ & E \\
\hline $\begin{array}{l}\text { Freight car, } \\
\text { caboose } \\
\text { (low speed) }\end{array}$ & 116 & 1.30 & 0.045 & 0 & 0.015 \\
\hline $\begin{array}{l}\text { Freight car, } \\
\text { caboose } \\
\text { (high speed) }\end{array}$ & 195 & 3.48 & 0.000 & -14.9 & 0.362 \\
\hline Passenger car & 139 & 1.56 & 0.023 & 0 & 0.056 \\
\hline Tirst lucumulive & 116 & 1.30 & 0.030 & 0 & .. 0.264 \\
\hline $\begin{array}{l}\text { Additional } \\
\text { locomotives }\end{array}$ & 116 & 1.30 & 0.030 & 0 & 0.045 \\
\hline
\end{tabular}

Sourco: Ref. 38:

Resistance values in pounds per ton of car wcight, plotted for single cars of typical weights in the middle of a train, are shown by Figure $B-1$.

The formulation is an extension of one originally proposed by W. J. Davis, Jr., and is based on measurements taken in 1910 by Professor Edward C. Schmidt of the University of Illinois and in 1937 by Professul J. K. Tuihl11. Fassenger train resistance was estimate. by A. 1. Tutten (Ref. 39). Later measurements, reported in Ref. 40, indicate values of resistance that are consistently 1 to 2 pounds per ton less than those that would be derived from the Schmidt-Tuthill. formulation. The formulation, shown by Table $B-1$, is widely used in the industry even though the lower values have been observed. Wide variarion in rolling resistance of cars in switchyards has been observed (Ref. 41), because of variation of lubricant viscosity with temperature and mechanical condition of cars. Empty cars frequently have higher resistance per ton than loaded cars. 


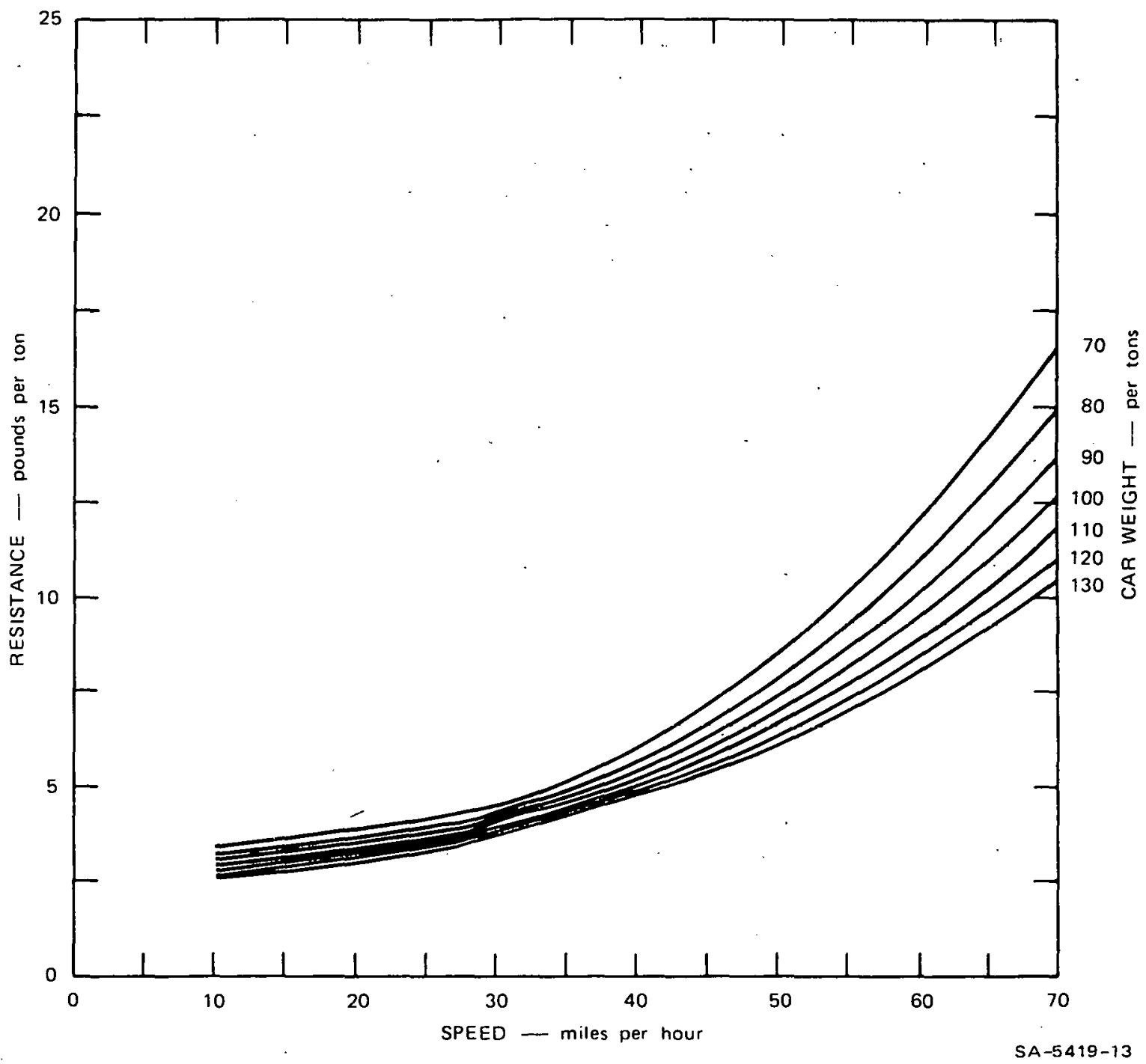

FIGURE B-1 FREIGHT CAR RESISTANCE

\section{Grade Resistance}

When the weight of the train must be lifted in elevation, a resistance component is introduced, because the slope of the track introduces a component of gravitational force in the longitudinal direction of the train. On an ascending grade the resistance is

$$
R_{g}=2,000 \mathrm{Wg}
$$


Where $R_{g}$ is the train resistance in pounds, $W$ is the train weight in tons, and $g$ is the tangent of the grade.

When descending, the resistance from the grade is negative. The limits of the negative value are explained by this discussion of classes of grades. Grades are classified by Hay (Ref. 39) according to the effect on train operation. A Class A grade will usually not require changes in throttle position or application of brakes to maintain train speed within limits. A grade with less than 30 feet of "rise and fall" ( 30 feet of ascent plus 30 feet of descent) with the slope less than $0.06 \%$ is considered Class A. A Class B grade is one that will require a slight throttle adjustment when going over the crest, but which will not require braking on descent. Thus, a descending Class $B$ grade will subtract the $f u l l$ amount of the gradeinduced forces from the total train resistance. When the grade resistance component on a descending grade is greater than the other resistlve forces, the train will tend to speed up unless brakes are applied. Grades on which these conditions occur are r.lassified as $\mathrm{C}$ grades. Thus, the brake application effectively limits the negative amount of the grade resistance. Class $C$ grades are those that exceed approximately $0.3 \%$ (Ref. 21).

\section{Curve Resistance}

Additional resistance is encountered as the train negotiates curves because of the forces of the wheel flanges on the rails (Ref. 40). The resistance approximates $0.8 \mathrm{lbs}$. per ton per degree of curvature (Ref. 40). $\Lambda$ railroad curve is measured in degrees of central angle subtended by a chord of 100 feet (Ref. 21).

\section{Acceleration Resistance}

Accelerating the train mass requires a force that is seen as a resistance of the train. The expression for the force of acceleration is a familiar one from physics, modified for the units common in railroad andysis:

$$
\mathrm{R}_{\mathrm{a}}=\frac{2000 \mathrm{~W}}{32.2} \mathrm{a}(1.467), \mathrm{nr} 91.1 \mathrm{aW}
$$

where $R_{0}$ is the reoiotance duc to neceleration, in puudb, a ls the acceleration in miles per hour per second, and $W$ is the train weight in tons.

* Railroad grades are measured in percent, equal to 100 times the tangent of the angle of the slope. 
Work Required to Overcome Train Resistance-

The work done to move the train is the product of the resistive force of the train and the distance over which the force acts, or, in general,

$$
\text { Work }=\frac{1}{2000} \int_{i}^{j} R_{t} d x
$$

where work is expressed in foot-tons, $R_{t}$ is the train resistance in pounds, and $x$ is the distance over which the instantaneous train resistance acts, in feet. The beginning and ends of the road segment being analyzed are $i$ and $j$.

In this preliminary formulation, it appears that a formulation that accounts for the work to overcome train resistance on level track, corrected for grade, acceleration, and curvature components is the most convenient for use. The formulation may be modified for the purpose for which it is used.

\section{Work to Overcome Resistance on Level Tangent Track}

The work component to move the train from one location to another over level ground is the distance of the segment times the train resistance at the average speed over the segment. The formula for the work is

$$
\text { work on level, tangent track } \begin{aligned}
& \frac{5280}{2000} \times \text { Distance } \times R_{1} \\
& =2.64 \times \text { Distance } \times R_{1}
\end{aligned}
$$

where the work is in foot-tons, the Distance is in miles, and $R_{1}$ is the resistance of the train in pounds.

\section{Work Done to Overcome Grades}

The treatment of grades will depend upon the level of detailed information available about the railroad being analyzed. If track charts are available, each segment with a different grade may be analyzed for movement in both directions. Under these circumstances, the additional work done to ascend grades is

$$
\text { Work on ascending grades }=W_{t} \times \text { Total ascents }
$$


where the work is in foot-tons, $W_{t}$ is the train weight in tons, and the total ascents are the feet of rise measured on all ascending grades in the segment under consideration. Descents on Class A grades will be ignored, while the descent energy for Class B grades is

Work Credit on Class $B$ grades $=-$ total descent $\mathrm{x} W_{t}$

where the work is in foot tons and the descent is measured in feet on Class B grades. In other words, descents on Class B grades contribute work toward movement of the resistance of the train. On the other hand, only a part of the work produced by descent on Class C grades is recoverable, the remainder being dissipated in braking. On Class $C$ grades, the work credit to the descent is

$$
\text { Work credit on Class } \mathrm{C} \text { grades }=-\mathrm{R}_{1} \mathrm{x} \text { distance over. }
$$

which Class $C$ grade prevails X 2.64

where the work is in foot-tons, $R_{1}$ is the train resistance on level, tangent track, in pounds, and the distance is in miles.

Under circumstances where large areas are hetng analyzed and it is not possible to use the detail of track charts, or they are not available, the work to raise the train weight over the total change of elevation of a line is computed,

$$
\text { Work on grade }=\text { increase in elevation } \mathrm{x} \mathrm{W}_{\mathrm{t}} \text {. }
$$

For the descending grade, it is assumed that the majortty of the descent is at the ruling grade, which can usually be found. Then,

$$
\text { Work credit on downgrade }=-\frac{\text { clevation change } \times R_{1}}{\text { rul1ng grate }}
$$

where the ruling grade is expressed as a decimal fraction, and $R_{1}$ is the train resistance on level tangent track.

On line segments having the same tonnage in both directions, it may be assumed that the work done to overcome the grade in the ascending direction is regained in the descending direction if braking is not required. Thus, only the work which cannot be recovered because of brake requirements need be considered as an addition to the work requirement attributed to the grade. Figure B-2 illustratcs a grade with such balanced traffic, with the vertical scale exaggerated. The assumed limit for a Class $C$ grade is $0.3 \%$. a grade on whirh a train with a resistance of 6 pounds per ton would maintain its speed. If the actual grade were greater, for example, $0.5 \%$, braking would 


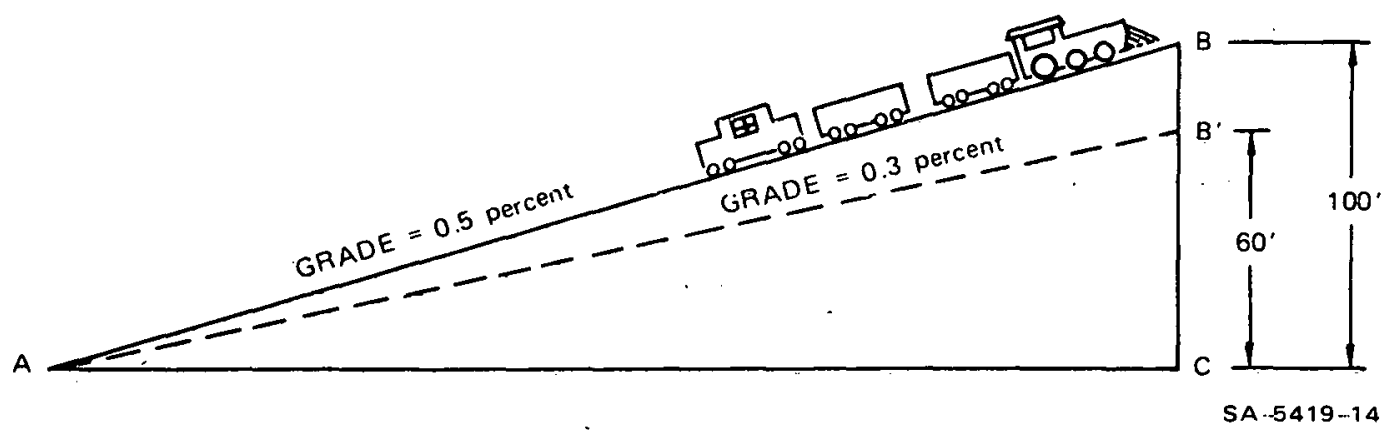

FIGURE B-2 ILLUSTRATION OF CLASS C GRADE ENERGY REQUIREMENT

be required to maintain speed. In the illustration, the grade has a total ascent, $B C$, of 100 feet, and the slope of the grade is 0.005 . The rise of a grade of 0.003 over the same distance would be the distance $B C$, an ascent of 60 feet in the assumed example. Work supplied to raise a train from $A$ to $B$ less the work recovered in lowering it from $B$ to $A$, is the increment of work lost. Thus, the work addition because of the grade in this balanced case is the train weight times the height $B B$, or 40 feet times the train welght in tons.

The general expression for this wark increment on Class $\mathrm{C}$ grades with balanced traffic is

Work required for equal movement in two directions $=$

$$
\frac{g-g_{C}}{g} \times \text { total altitude change of the grade } x w_{t} \text {. }
$$

where $g$ is the grade of the hill, $g_{C}$ is the grade equivalent to maintenance of constant train speed, and $W_{t}$ is the train weight in tons. The grade $g_{C}$ is numerically equal to $1 / 2000 t h$ of the train resistance per ton.

\section{Work to Overcome Curvature}

The curvature resistance is converted into energy by converting our assumed resistance of 0.8 pound per ton per degree of curvature to its equivalent grade of 0.0004 per degree of curvature and assuming that the length of the grade is the 100 foot chord that subtends the measurement degree. Thus,

$$
\begin{array}{r}
\text { work due to curvature }=0.0004 \times 100 \times \text { degree of } \\
\text { curvature } \times W_{t} .
\end{array}
$$


This is equivalent to an ascent of 0.04 feet per degree of curve.

\section{Work to Accelerate the Train}

The integral of the expression for the resistance due to acceleration is

$$
\text { Work to accelerate the train }=0.0334\left(\mathrm{~s}_{1}{ }^{2}-\mathrm{s}_{2}{ }^{2}\right) \text {. }
$$

where the work is in foot-tons, the speeds are in miles per hour. The expression is only for increasing speed, since decreasing speed is accomplished by braking in most cases.

\section{Conversion of Fuel to Work}

The work to move the train must he provided by a locomotive that utilizes a diesel-fueled prime mover and a transmission system, or which collects electrical energy from wayside farilities and produces the work with electric motors on the locomotive.

\section{Diese1-Electric Locomot1ve Power}

The tuel consumption of a diesel-electric locomotive may be estimated from the total time of operation of the locomotive, the work done to move the train, and the fuel consumption rates for the locomotive.

\section{Idle Fuel Consumption}

In this formulation, the idip fuel consumption io aooumed to prevai.1 nver the time that the locomotive is pulllug a train, in addition to the fuel consumed in overcoming the train resistance. The idle fuel consumption is a significant portion of the total fuel consumption not on $1 \mathrm{y}$ because of compression work and friction losses in the engine, but also because of auxiliary power draw from the engine to operate air compressors for brake control and for cooling fans and electrical power requirements for the locomotive. According to Hopkins (Ref. 38), idle fuel consumption in pounds per hour may be estimated from the equation:

$$
f_{i}=0.0150 \times \text { rated horsepower. }
$$

At 7.3 pounds per gallon density, this becomes about 0.0021 gallons per rated horsepower per hour. A $3000 \mathrm{hp}$ locomotive will consume about 6 gallons per hour at idle, an 1,800 hp unit about 4 (Ref. 42). 
A diesel locomotive is most susceptible to damage when it is being started, as temperatures equalize, and coolant and lubricant flows must be carefully monitored. In addition, the coolant is subject to freezing in cold weather. For these reasons, locomotives are frequently idled continuously unless they are in the shops for service. Estimates of idle time are $43 \%$ for road engines and $77 \%$ for switch engines (Ref. 38).

\section{Work Output from the Engine and Transmission}

The diesel engine drives a generator which, in turn, drives electrical motors on the trucks to produce the tractive effort of the locomotive. It is assumed that the drive train, including the generator, conversion equipment, and motors, is about $80 \%$ efficient.

The locomotive is controlled by a throttle unit that usually has nine positions, or notches, which provide for increasing power output from 0 (idle) through 8 (maximum). The rotational speed of the engine increases as the throttle is advanced, with controls on fuel, supercharger (if equipped), and the generator to maintain voltage, current, and engine revolutions in limits. Because of the variable speed and other characteristics of the engine, the efficiency of the engine increases as increasing loads are placed on it. Figure B-3 shows data derived from Reference 42, on specific fuel consumption for a 3,000-hp locomotive engine. In the analysis, the idle fuel consumption was deducted before the fuel consumption was computed. Irregularities in the curve at higher notches appear to be caused by increased action of the supercharger.

The fuel consumption component to produce work to move the train may be estimated from the expression:

$$
f_{w}=\operatorname{sfc} \times \frac{1}{e} \times \frac{\text { train work required }}{990}
$$

where $f_{w}$ is the component of fuel consumption needed to produce the traction work for the train, in pounds or gallons; sfc is the specific fuel consumption of the engine in pounds or gallone per hpmr; $e$ is the drive train efficiency, assumed to be .8; and the train work required is in foot-tons.

The variability of the specific fuel consumption is accounted for in a duty cycle that will produce an effective average of the fuel consumption in each throttle notch, weighted by the time that that power setting is used. Table B-2, sluws the duty cycle for a 3,000-hp locomotive. The adjusted (exclusive of idle) fuel consumption corrected for duty cycle is $0.053 \mathrm{gal} / \mathrm{hp} \mathrm{hr}$, while the unadjusted weighted average is $0.059 \mathrm{gal} / \mathrm{hp}-\mathrm{hr}$. 


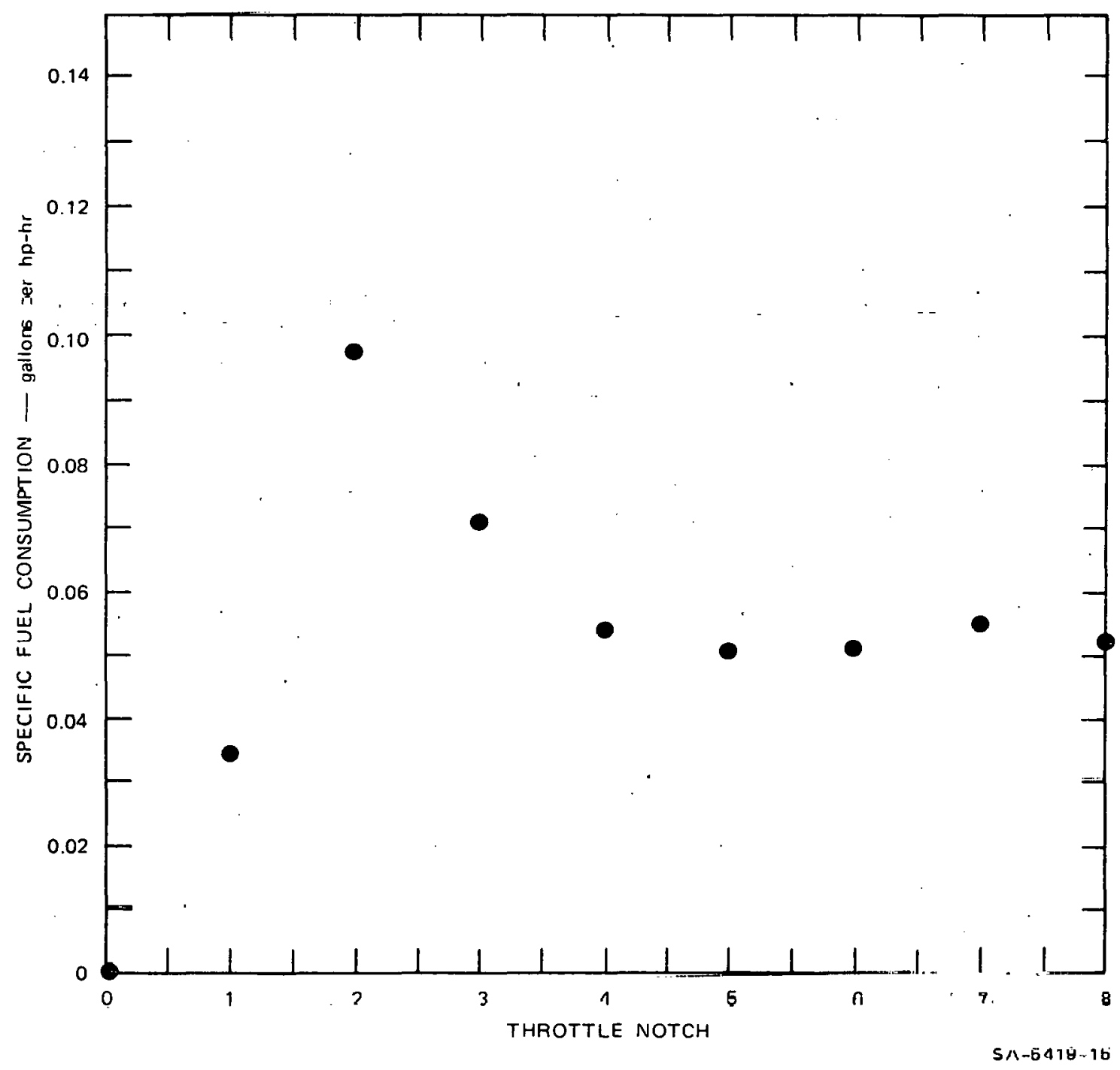

FIGURE B-3 SPECIFIC FUEL CONSUMPTION FOR SD-45 LOCOMOTIVE (Idle fuel rate doductcd from consumption at dill throtile setitings) 
Table $B-2$

OPERATION DATA FOR EMP SD-40 LOCOMOTIVE

\begin{tabular}{|c|c|c|c|c|c|}
\hline $\begin{array}{l}\text { Throttle } \\
\text { Position }\end{array}$ & $\begin{array}{l}\text { Delivered } \\
\text { Horsepower }\end{array}$ & Operation & $\begin{array}{c}\text { Work } \\
\text { Delivered } \\
\text { (hp-hr) }\end{array}$ & $\begin{array}{c}\text { Fuel } \\
\text { Rate } \\
\text { (gal/hr) }\end{array}$ & $\begin{array}{l}\text { Consumption } \\
\text { (ga1) }\end{array}$ \\
\hline 8 & 3,100 & 3.6 & 11,160 & 168 & 605 \\
\hline 7 & 2,550 & 1.0 & 2,550 & $\overline{146}$ & 146 \\
\hline 6 & 2,000 & 1.0 & 2,000 & 108 & 108 \\
\hline 5 & 1,450 & 1.0 & 1,450 & 79 & 79 \\
\hline 4 & 950 & 1.0 & 950 & 57 & 57 \\
\hline 3 & 500 & 1.0 & 500 & 41 & 41 \\
\hline 2 & 200 & 1.0 & 200 & 25 & 25 \\
\hline 1 & 58 & 1.2 & 70 & 7.5 & 9 \\
\hline idle & * & 12.0 & 500 & 5.5 & 66 \\
\hline Dyn.Brake & * & 1.2 & 240 & 25 & 30 \\
\hline Total & - & 24.0 & 19,620 & - & 1,166 \\
\hline
\end{tabular}

Source: Ref. 42.

\section{Electric Locomotives}

Electric locomotives draw electrical energy from a third rail or overhead catenary circuit and use the electrical energy to drive motors that power the drive wheels. Estimated energy conversion efficiency at the central station generating plant is about $33 \%$, and transmission, distribution, and traction motor losses vary from 10 to $20 \%$. Thus, for each the energy requirements at the central station are:

$$
\begin{aligned}
\text { central station energy } & =\frac{2,545 \times \text { traction hp-hr }}{0.33 \times 0.85} \\
& =9, n 73 \mathrm{R}+11 \text { per traction hp-hr }
\end{aligned}
$$


THIS PAGE

WAS INTENTIONALLY

LEFT BLANK 
1. Association of American Railroads, Yearbook of Railroad Facts, 1975 Edition, Washington, D.C.

2. Association American Railroads, A Chronology of American Railroads, Washington, D.C. (1962).

3. Association of American Railroads, Railroad Transportation: A Statistical Record, Washington, D.C. (Various Years).

4. President's Advisory Committee on a National Highway Program, A Ten-Year National Highway Program, (The "Clay Committee Report"), Washington, D.C. (January 1955).

5. J.F. Stover, American Railroads, The Chicago History of American Civilization Series, The University of Chicago Press (1961).

6. Bureau of the Census, Historical Statistics of the United States, Colonial Times to 1957, Washingt on, D.C. (1960).

7. Interstate Commerce Commission, Annual Report, Washington, D.C. (Various Years).

8. Task Force on Railroad Productivity, Improving Railroad Productivity, (Final Report to The National Commission on Productivity and The Council of Economic Advisors), Washington, D.C. (November 1973).

9. Kolko, Gabriel, Railroads and Regulations, 1877-1916, W. W. Norton \& Company, New York (1965).

10. S.J. Petracek et al., "Railroad Classification Yard Technology A Survey and Assessment", Stanford Research Institute, U.S. Department of Transportation, Federal Railroad Administration, Transportation Systems Center, July 1976, DOT-TSC-968.

11. "Eighty-Eighth Annual Report on Transportation Statistics in the United States for the Year Ending December 31, 1974, Interstate Commerce Commission, Bureau of Accounts, Washingt on, D.C.

12. "Eighty-Seventh Annual Report on Transport Statistics in the United States for the Year Ended December 31, 1973", Interstate Commerce Commission, Bureau of Accounts, Washington, D.C. 
13. Pocket List of Railroad Officials. "A Sound Approach to Railroad Markets", National Railway Publication Company, New York, N.Y. (1976).

14. "Preliminary Standards, Classification, and Designation of Lines of Class 1 Railroads in the United States", Volumes I and II, U.S. Department of Transportation (3 August 1976).

15. "Survey of Railroad Facilities", Unpublished Results, United States Department of Transportation, Federal Railroad Administration (no date).

16. "Transportation Zone Maps", Department of Transportation (January 1974).

17. Railroad Locomotive and Cars, Simmons-Boardman Publishing Corp., New York, N.Y. (April 1974).

18. "Yearbook of Railroad Facts": 1976 Edilion, Association of American Railroads, Washington, D.C.

19. "Raj1 Carload Cost Scales for 1973, "Interstate Commerce Commission Bureau of Accounts, Stacement ICI $=73$, Wásliington, C.D.

20. Danzig, Jerry C., et a1., "Procedures for Analyzing the Economic Costs of Railroad Roadway for Pricing Purposes--Volume I, Procedures." Federal Railroad Administration Report RPD-11-CM-R, Volume I, prepared by TOPS On-Line Services Inc., San Francisco, DOT-FR-30028.

21. A.E. Moon, et al., "Guidebook For Planning to Alleviate Urban Railroad Froblems:" Volume 3, Stanford Research Institute, United States Department of Transportation, federal Ra1lroad Administration, Federal llighway Adminiotration (August 1.974) DOT-FR-20037.

22. "Report to Congress - Railroad-Highway Safety Part II: Recommendations for Resolving the Problem", United Stares Department: of Transportation (August 1972).

23. Association of American Railroads. "Stat1stles ur Railroads of Class I in the United States - Years 1964 Lu 1974." Statistical Summary Number 59, Ecollumics and Finance Department, Washington, D.C. (July 1975). 
24. Procedures for Analyzing the Economic Costs of Railroad Roadway for Pricing Purposes, U.S. Dept. of Transportation, Federal Railroad Administration, (January 1976).

25. F.E. Shaffa and R. Roberts, "Hump Yards: Are the Critics Right?", Modern Railroads, p. 55 (July 1973).

26. "USRA Yard Classification Project: Maximum Throughput and Associated Expenditures and Selected Yard", R. L. Hines Associates, Inc., Washington, D.C. (2 January 1975).

27. Theodore E. Keeler, "Railroad Costs, Returns to Scale and Excess Capacity", The Review of Economic and Statistics, pp. 201-208 (May 1974).

28. Z. Griliches, "Railroad Cost Analysis", The Bell Journal of Economics and Management Sctence, pp. 26-41 (Spring 1972).

29. R.J. Pozdena, "Estimating Cost Functions for Rail Rapid Transit Properties", Transportation Research (in press).

30. R.H. Leilich, J.C. Prokopy, and D. Ruina, "Industrial Energy Studies of Ground Freight Transportation. Volume I." Peat, Marwick, Mitche 11 and Company, Federal Energy Administration (July 1974) DI-14-01-001-1670.

31. R.A. Herendeen and C.W. Bullard, "Energy Cost of Goods and Services, 1963 and 1967," University of Illinois Center for Advanced Computation Document No. 140 (November 1974).

32. Berry, R.S. and M.F. Fels, "The Production and Consumption of Automobiles", Department of Chemistry, University of Chicago, 60637 (July 1972).

33. United States Railway Association. "Final System Plan, Volume I (Parts I and II) - for Restructuring Railroads in the Northeast and Midwest Region Pursuant to the Regional Rail Reorganization Act of 1973", (26 July 1975).

34. H. Gannett, "A Dictionary of Altitudes in the United States." Fourth Edition, Bullet in No. 274, Series F, Geography 47, United States Geological Survey, Department of the Interior, Washington, D.C. (1906).

35. "Handy Railroad Atlas of the United States" Rand McNally (1973). 
36. The Offlcial Railway Guide - North American Freight Service Edition, National Railway Publication Company, New York.

37. "Moody's Transportation Manual", Moody's Investors Service, Inc. New York 10007 (1974).

38. J.B. Hopkins, "Railroads and the Environment--Estimation of Fuel Consumption in Rail Transportation", Volume I, Analytical Model. Transportation Systems Center, Cambridge, Mass. (May 1975).

39. W.W. Hay, Railroad Engineering, John Wiley \& Sons, New York (1953).

40. Tope, D.W., "Rolling Resistance of Freight Cars", The Timken Company (11 June 1971).

-41. K.W. Gardiner, D.W. Ross, M.W. Siddiqee, and P.J. Wong, "Design of High-Throughput Hump Yards", Stanford Research Institute, Menlo Park, California (June 1969).

42. J.N. Cetinich, "Fuel Efficiency Improvement in Rail Freight Transportation", Report Number FRA-OR\&D-76-136, U.S. Department of Transportation, Transportation Systems Center, Cambridge, Mass. (December 1975). 